Historic, archived document

Do not assume content reflects current scientific knowledge, policies, or practices. 

A94.

F $7644 \mathrm{~b}$

$\operatorname{cop} 3$

United States

Department of

Agriculture

Forest Service

Intermountain

Research Station

Resource Bulletin

INT-53

Timberland and Woodland Resources Outside National

uiss

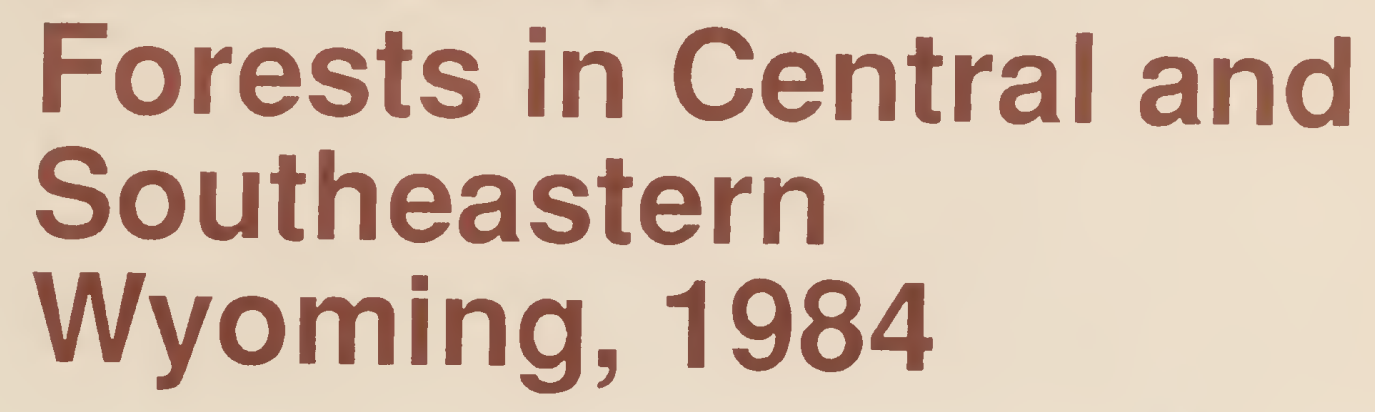

Alan W. Green

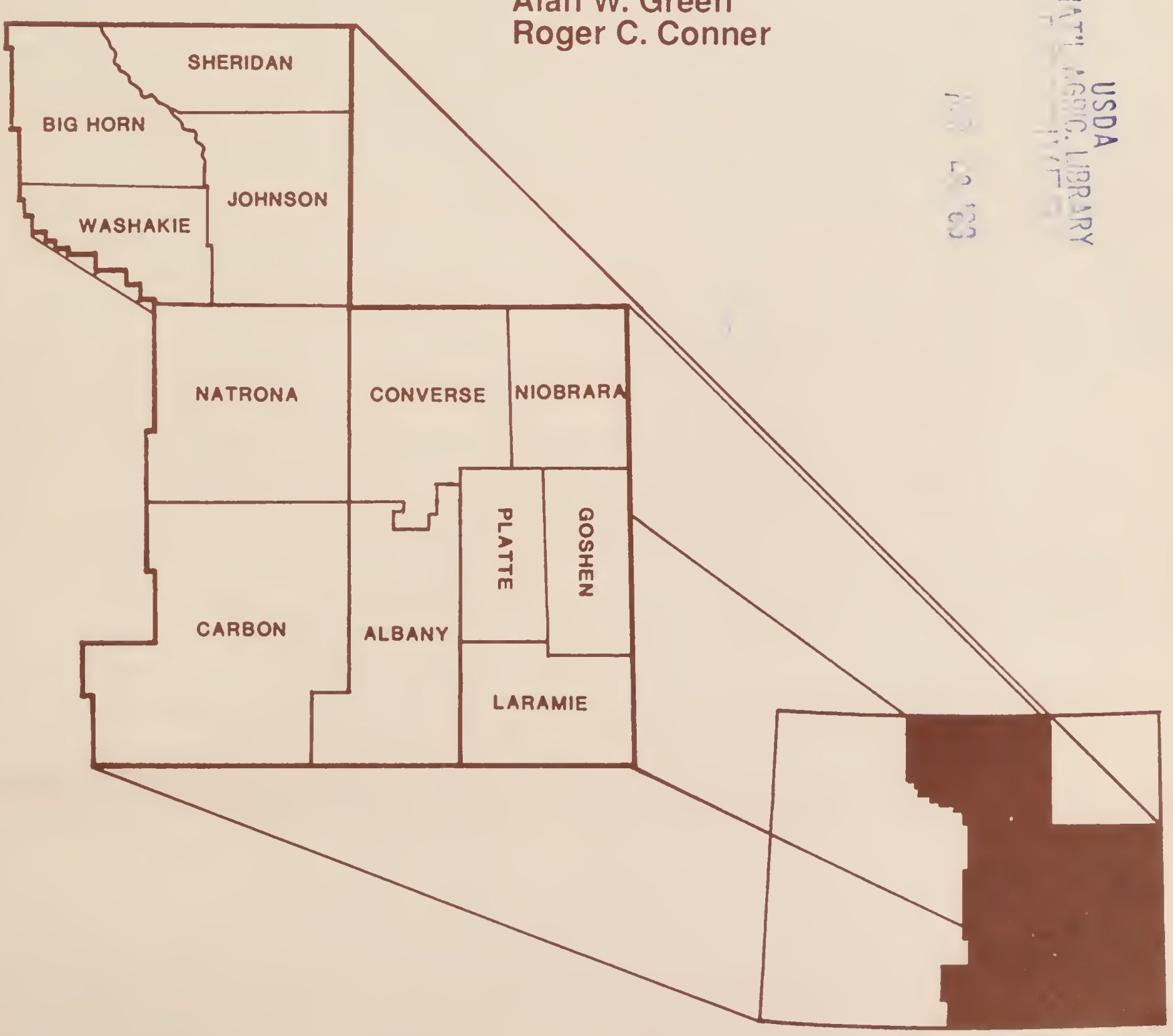




\section{PREFACE}

Forest Survey is a continuing nationwide undertaking conducted by the Forest Service, U.S. Department of Agriculture, with the primary objective of providing an assessment of the renewable resources on the Nation's forests.

This requires periodic State-by-State resource inventories. Originally, Forest Survey was authorized by the McSweeneyMcNary Act of 1928. The current authorization is through the Renewable Resources Research Act of 1978.

The Intermountain Research Station, with headquarters in Ogden, UT, administers the forest resource inventories for the Rocky Mountain States of Arizona, Colorado, Idaho, Montana, New Mexico, Nevada, Utah, Wyoming, western South Dakota, western Texas, and Oklahoma's Panhandle. These inventories provide information on the extent and condition of State and privately owned forest lands, volume of timber, and rates of timber growth and mortality. These data, when combined with similar information for Federal lands, provide a basis for forest policies and programs and for the orderly development and use of the resources.

\section{THE AUTHORS}

ALAN W. GREEN is principal resource analyst in the Forest Survey Research Work Unit at the Intermountain Research Station. His career has included research in silviculture and regeneration, economics of timber production, and foreign forestry resources. In addition to a degree in economics, he holds both B.S. and M.S. degrees in forestry from Purdue University.
ROGER C. CONNER is a forester with the Forest Survey Research Work Unit at the Intermountain Station. His primary area of responsibility is in resource analysis. He holds a B.S. degree in forestry from Virginia Polytechnic Institute and State University. He began his Forest Service career with the Intermountain Research Station in 1980.

\section{ACKNOWLEDGMENTS}

This report is the result of the combined efforts of numerous people on the Forest Survey staff. In addition to the photo interpretation and field crews, several individuals played key roles in the reduction of basic data into information describing the extent, nature, and condition of the forest resources in Wyoming: Dennis Collins supervised the data collection; Sharon Woudenberg and Shirley Waters compiled the data and made summaries; and Susan Brown transformed the data summaries into tables of information. And we extend a special note of gratitude to the private land owners who allowed the field crews access to the sample locations on their properties.

\section{RESEARCH SUMMARY}

Highlights the results of forest inventory of the 12 counties in central and southeastern Wyoming. Presents area, volume, growth, and mortality statistics for both timberland and woodlands outside the National Forests as of 1984. 


\section{CONTENTS}

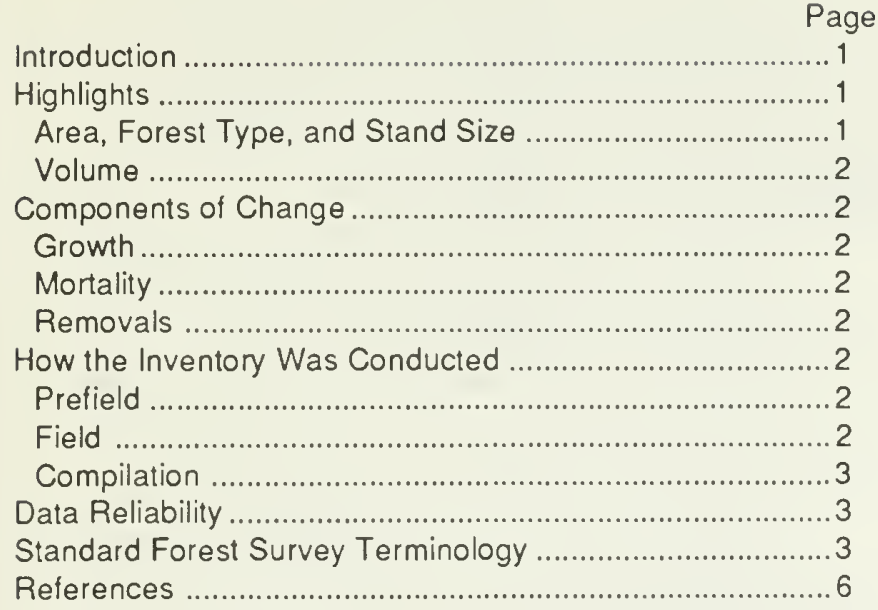

Forest Survey Tables

1. Total land and water area by ownership class in central-southeastern Wyoming, 1984

2. Area of forest land outside National Forests with percent standard error in central-southeastern Wyoming, 1984

3. Net volume, net annual growth, and annual mortality of growing stock and sawtimber on timberland outside National Forests with percent standard error in central-southeastern Wyoming ....... 8

4. Total land area outside National Forests by major land class and ownership class in central-southeast Wyoming, 1984

5. Area of forest land outside National Forests by forest type, ownership class, and land class in centralsoutheast Wyoming, 1984

6. Cubic feet of net volume in trees on forest land outside National Forests by species and ownership class in central-southeast Wyoming, 1984 .............. 10

7. Cubic feet of net annual growth in trees on forest land outside National Forests by species and ownership class in central-southeast Wyoming, 1983

8. Cubic feet of annual mortality in trees on forest land outside National Forests by species and ownership class in central-southeast Wyoming, 1983

9. Area of timberland outside National Forests by forest type, stand-size class, and productivity class in central-southeast Wyoming, 1984

10. Area of other publicly owned timberland by forest type, stand-size class, and productivity class in central-southeast Wyoming, 1984

11. Area of privately owned timberland by forest type, stand-size class, and productivity class in centralsoutheast Wyoming, 1984

12. Area of timberland outside National Forests by stand volume and ownership class in central-southeast Wyoming, 1984

13. Area of timberland outside National Forests by forest type and area condition class in central-southeast Wyoming, 1984
14. Number of growing-stock trees on timberland outside National Forests by species and diameter class in central-southeast Wyoming, 1984

15. Number of cull and salvable dead trees on timberland outside National Forests by ownership class, and softwoods and hardwoods in centralsoutheast Wyoming, 1984

16. Net volume of growing stock on timberland outside National Forests by ownership class, forest type, and stand-size class in central-southeast Wyoming, 1984

17. Net volume of sawtimber (International $1 / 4$-inch rule) on timberland outside National Forests by ownership class, forest type, and stand-size class in central-southeast Wyoming, 1984 . 22

18. Net volume of sawtimber (Scribner rule) on timberland outside National Forests by ownership class, forest type, and stand-size class in centralsoutheast Wyoming, 1984

19. Net volume of growing stock on timberland outside National Forests by species and ownership class in central-southeast Wyoming, 1984

20. Net volume of sawtimber (International $1 / 4$-inch rule) on timberland outside National Forests by species and ownership class in central-southeast Wyoming, 1984

21. Net volume of sawtimber (Scribner rule) on timberland outside National Forests by species and ownership class in central-southeast Wyoming, 1984

22. Net volume of growing stock on timberland outside National Forests by species and diameter class in central-southeast Wyoming, 1984

23. Net volume of sawtimber (International $1 / 4$-inch rule) on timberland outside National Forests by species and diameter class in central-southeast Wyoming. 1984

24. Net volume of sawtimber (Scribner rule) on timberland outside National Forests by species and diameter class in central-southeast Wyoming. 1984

25. Net volume of timber on timberland outside National Forests by class of timber, and softwoods and hardwoods in central-southeast Wyoming, 1984 ............. 29

26. Net volume of growing stock on timberland outside National Forests by forest type and species in central-southeast Wyoming, 1984

27. Net volume of sawtimber (International $1 / 4$-inch rule) on timberland outside National Forests by forest type and species in central-southeast Wyoming, 1984

28. Net volume of sawtimber (Scribner rule) on timberland outside National Forests by forest type and species in central-southeast Wyoming, 1984

29. Net annual growth of growing stock on timberland outside National Forests by species and ownership class in central-southeast Wyoming, 1983 
30. Net annual growth of sawtimber (International $1 / 4$-inch rule) on timberland outside National Forests by species and ownership class in central-southeast Wyoming, 1983

31. Net annual growth of sawtimber (Scribner rule) on timberland outside National Forests by species and ownership class in central-southeast Wyoming, 1983

32. Net annual growth of growing stock on timberland outside National Forests by species and diameter class in central-southeast Wyoming, 1983

33. Net annual growth of sawtimber (International $1 / 4$-inch rule) on timberland outside National Forests by species and diameter class in central-southeast Wyoming, 1983

34. Net annual growth of sawtimber (Scribner rule) on timberland outside National Forests by species and diameter class in central-southeast Wyoming, 1983

35. Annual mortality of growing stock on timberland outside National Forests by species and ownership class in central-southeast Wyoming, 1983 .............38

36. Annual mortality of sawtimber (International $1 / 4$-inch rule) on timberland outside National Forests by species and ownership class in central-southeast Wyoming, 1983

37. Annual mortality of sawtimber (Scribner rule) on timberland outside National Forests by species and ownership class in central-southeast Wyoming, 1983

38. Annual mortality of growing stock on timberland outside National Forests by species and diameter class in central-southeast Wyoming, 1983 .............40 40

39. Annual mortality of sawtimber (International $1 / 4$-inch rule) on timberland outside National Forests by species and diameter class in central-southeast Wyoming, 1983

40. Annual mortality of sawtimber (Scribner rule) on timberland outside National Forests by species and diameter class in central-southeast Wyoming, 1983

41. Annual mortality of growing stock on timberland outside National Forests by species and cause of death in central-southeast Wyoming, 1983.

42. Annual mortality of sawtimber (International $1 / 4$-inch rule) on timberland outside National Forests by species and cause of death in central-southeast Wyoming, 1983

43. Annual mortality of sawtimber (Scribner rule) on timberland outside National Forests by species and cause of death in central-southeast Wyoming, 1983

44. Area of woodland outside National Forests by forest type and ownership class in central-southeast Wyoming, 1984
45. Area of woodland outside National Forests by ownership class, forest type, and productivity class in central-southeast Wyoming, 1984

46. Area of woodland outside National Forests by ownership class, forest type, and volume class in central-southeast Wyoming, 1984

47. Number of trees on. woodland outside National Forests by ownership class, species, and diameter class in central-southeast Wyoming, 1984

48. Net volume of woodland outside National Forests by species and ownership class in central-southeast Wyoming, 1984

49. Net volume of woodland species on woodland outside National Forests by ownership class, species, and diameter class in central-southeast Wyoming, 1984

50. Net volume of woodland species on woodland outside National Forests by ownership class, forest type, and productivity class in central-southeast Wyoming, 1984 . 50

51. Net volume of woodland species on woodland outside National Forests by ownership class, forest type, and volume class in central-southeast Wyoming, 1984

52. Net dead volume of woodland species on woodland outside National Forests by ownership class, species, and diameter class in centralsoutheast Wyoming, 1984

53. Net dead volume of woodland species on woodland outside National Forests by ownership class, forest type, and productivity class in centralsoutheast Wyoming, 1984

54. Net dead volume of woodland species on woodland outside National Forests by ownership class, forest type, and volume class in centralsoutheast Wyoming, 1984

55. Net annual growth on woodland outside National Forests by species and ownership class in centralsoutheast Wyoming, 1983

56. Net annual growth of woodland species on woodland outside National Forests by ownership class, species, and diameter class in centralsoutheast Wyoming, 1983

57. Net annual growth of woodland species on woodland outside National Forests by ownership class, forest type, and productivity class in centralsoutheast Wyoming, 1983

58. Net annual growth of woodland species on woodland outside National Forests by ownership class, forest type, and volume class in centralsoutheast Wyoming, 1983

59. Number of fenceposts on woodland outside National Forests by ownership class, species, and type of post in central-southeast Wyoming, 1984 


\title{
Timberland and Woodland Resources Outside National Forests in Central and Southeastern Wyoming, 1984
}

\author{
Alan W. Green \\ Roger C. Conner
}

\section{INTRODUCTION}

For the latest inventory of the forest land in Wyoming, completed in 1983, the State was divided into three multicounty Sample Areas. Within those Sample Areas all nonreserved forest lands, including woodland, not under the administration of the Forest Service, were inventoried.

Sample Area 2, the subject area of this report, is second largest in geographic area and comprises 12 counties in the central and southeastern portions of the State (fig. 1). Sample Areas 1 and 3 cover the rest of the State and are subjects of separate reports.

Data in this report pertain only to the lands outside the National Forests. Data for public lands administered by agencies such as the USDI Bureau of Land Management (BLM) and the State of Wyoming are included along with those for privately owned lands.

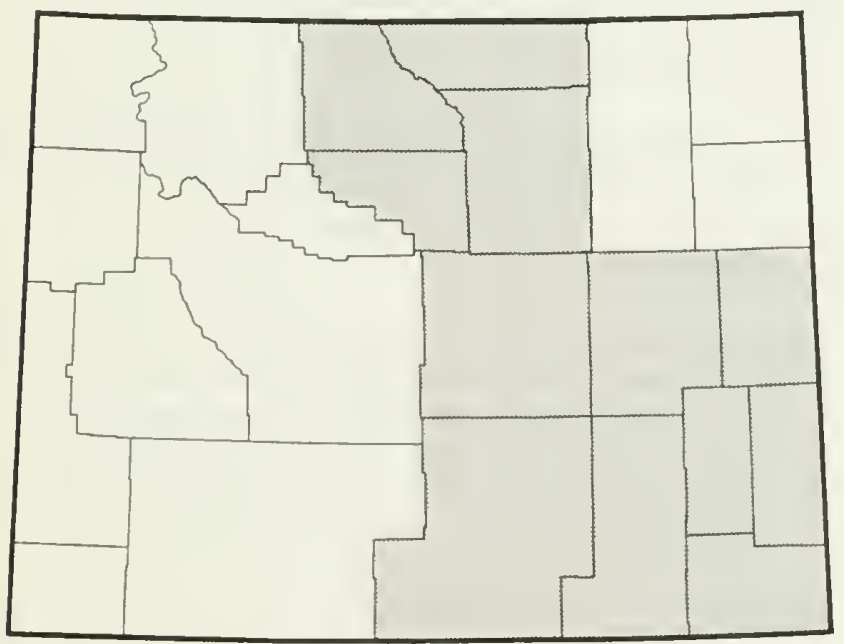

Figure 1-Sample Area 2, central-southeastern Wyoming.

\section{HIGHLIGHTS}

\section{Area, Forest Type, and Stand Size}

Land area outside the National Forests is approximately 25.4 million acres, of which some 1.3 million are forest. Much of the forest land is found in the higher elevations, primarily in the Bighorn, Laramie, and Medicine Bow Mountains (fig. 2). (See table 1 for total land and water area by ownership class.)

Roughly 79 percent of the forest land is timberland and is predominantly privately owned. The 281,000 acres of woodlands are largely on public land.

Three major forest types, ponderosa, lodgepole, and limber pine, make up about three-fourths of the timberland. The ponderosa pine forest type alone accounts for nearly half the timberland.

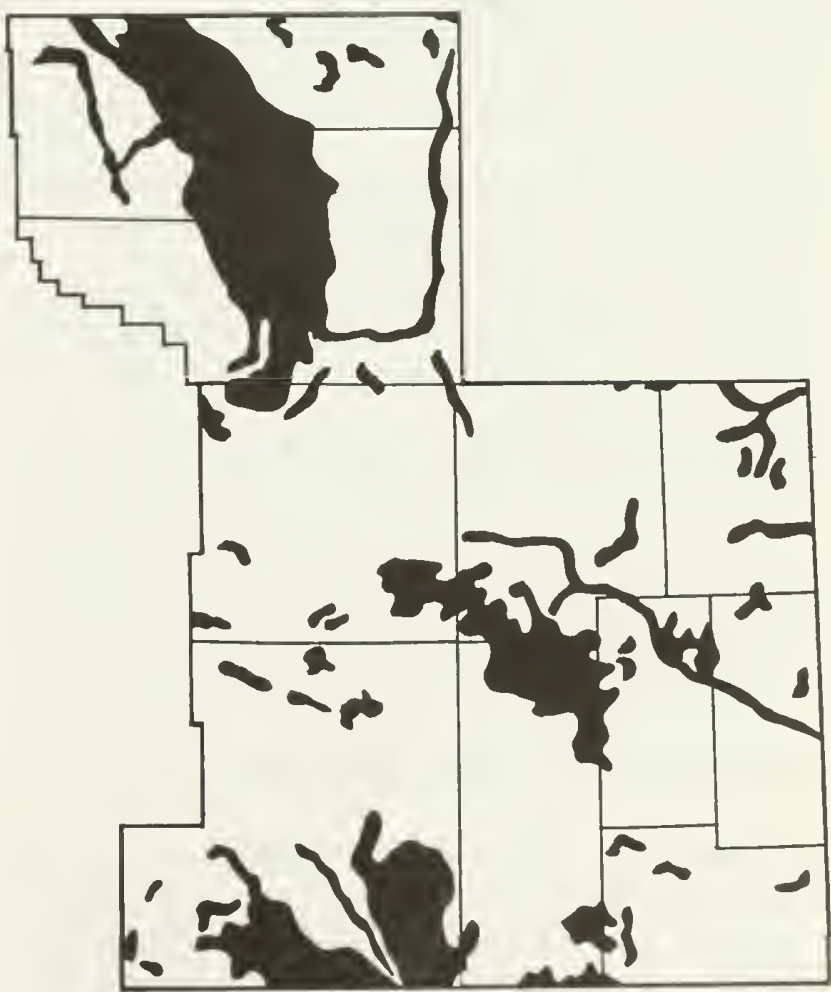

Figure 2-General geographic location of forest land 
Woodlands are predominantly Rocky Mountain juniper (Juniperus scopulorum), but about 10 percent are hardwoods, primarily in riparian zones along streams.

Productivity of the timberland is relatively low. Only about 20 percent can produce more than 50 cubic feet of usable wood per acre per year, and 11 percent cannot produce 20 cubic feet per acre.

Roughly 39 percent of the higher site timberland (capable of producing in excess of 50 cubic feet) is occupied by hardwoods. Spruce-fir and lodgepole pine are the major softwood forest types on better sites.

Sawtimber-size stands are the rule, making up 50 percent or more of the timberlands. About 194,000 acres of the timberland (nearly a fifth of the total) are nonstocked.

Privately owned timberland has a higher proportion in sawtimber stands than other publicly owned land.

\section{Volume}

Ponderosa pine (Pinus ponderosa) and lodgepole pine ( $P$. contorta) account for about 65 percent of the softwood and 57 percent of the growing-stock volume.

Aspen (Populus tremuloides) has 9 percent of the total and 76 percent of hardwood growing-stock volume.

Volumes per acre in sawtimber stands tend to be low; 80 percent of the timberland has less than 5,000 board feet (International 1/4-inch rule) per acre, and half the area has less than 1,500 board feet per acre.

The total net volume in timberland trees is slightly more than 1 billion cubic feet, 996 million in growing-stock trees. There are about 58.5 million cubic feet in salvable dead trees.

Some 868 million cubic feet ( 87 percent of the growingstock volume) is in softwood species. Softwood sawtimber volume is about 2.8 billion board feet (International $1 / 4$ inch rule).

Ponderosa and lodgepole pine make up 57 percent of the growing-stock volume.

Coniferous trees on timberland tend to be small; 83 percent of the softwood growing-stock trees are less than 9 inches diameter at breast height (d.b.h.).

The average d.b.h. of trees with measurable volume ( 5 inches d.b.h. and larger) is about 9 inches. The average diameter of sawtimber size trees $(9$ inches d.b.h. and larger) is about 13 inches.

Because of the small tree sizes, two-thirds of the sawtimber volume is in trees less than 17 inches d.b.h.

Net volume on woodlands is roughly 116.6 million cubic feet including some 3.5 million cubic feet in ponderosa and limber pine growing in woodlands.

Woodland volume is split about evenly between juniper and hardwoods.

\section{COMPONENTS OF CHANGE}

\section{Growth}

In 1983 the net annual growth of growing stock was about 20.5 million cubic feet; sawtimber growth was over 75 million board feet (International $1 / 4$-inch rule). Most of it was in softwood species and over half of it on private land.
Around 89 percent of the growing-stock growth was on trees less than 15 inches d.b.h.

Sawtimber growth was concentrated in trees less than 17 inches d.b.h. (88 percent), and over 70 percent was on trees less than 13 inches d.b.h.

\section{Mortality}

In 1983 approximately 4.1 million cubic feet of growing stock died, 58 percent of it in softwood species. Nearly all the hardwood mortality was in aspen (1.4 million cubic feet).

Ponderosa pine and Douglas-fir (Pseudotsuga menziesii) accounted for virtually all of the softwood sawtimber mortality of 6.9 million board feet (International $1 / 4$-inch rule).

The major identifiable causes of mortality were animal, weather, fire, and disease.

\section{Removals}

In 1983 nearly 10 million cubic feet of growing stock and approximately 58 million board feet (International ${ }^{1 / 4}$-inch rule) of saw timber were removed from timberlands, including the National Forests (McLain 1987). That was about a third of the removals in the State.

Nearly 70 percent came from public lands in Albany and Carbon Counties. Less than 6 percent of the total came from private land.

About 8 million board feet (International $1 / 4$-inch rule) (14 percent of the total) came from lands outside the National Forests, and of that nearly 39 percent came from private land.

Roughly 70 percent of the total removals were lodgepole pine.

\section{HOW THE INVENTORY WAS CONDUCTED}

The inventory was designed to provide reliable statistics primarily at the State and Sample Area levels.

\section{Prefield}

Primary area estimates were based on the classification of 113,079 sample points systematically placed on the latest aerial photographs available. The photo points, adjusted to meet known land areas by owner class, were used to stratify and compute expansion factors for the field sample data.

\section{Field}

Land classification and estimates for forest characteristics and volume were based on observations and measurements recorded at 4,090 ground sample locations, of which 192 were forested. Sample trees on timberland plots were selected using five-point cluster, which included 1/300-acre field radius plots for trees less than 5 inches d.b.h. and variable radius plots ( $40 \mathrm{BAF}$ ) for trees 5 inches or larger. 
Sample trees on woodland plots were selected using a $1 / 5-$, $1 / 10$-, or $1 / 20$-acre fixed plot for trees 3 inches diameter at root collar (d.r.c.) and larger. Trees less than 3 inches d.r.c. were tallied on a $1 / 100$-acre subplot.

\section{Compilation}

All photo and field data were entered into a computer for editing, computation, and tabulation. Final estimates from these data were based on statistical summaries, a portion of which is included in this bulletin. Volume and defect were computed using equations developed by Edminster and others (1980, 1981), Kemp (1958), Chojnacky (1985), Meyers (1964), Meyers and Edminster (1972). Defect for woodland species was computed from field observations.

\section{DATA RELIABILITY}

Individual cells within tables should be used with caution. Some are based on small sample sizes, which may result in high sampling errors. The standard error percentages shown in tables 2 and 3 were calculated at the 67 percent confidence level.

\section{STANDARD FOREST SURVEY TERMINOLOGY}

Acceptable trees-Growing-stock trees meeting specified standards of size and quality, but not qualifying as desirable trees.

Area condition class-A classification of timberland reflecting the degree to which the site is being utilized by growing-stock trees and other conditions affecting current and prospective timber growth (see Stocking):

Class 10-Areas fully stocked with desirable trees and not overstocked.

Class 20-Areas fully stocked with desirable trees, but overstocked with all live trees.

Class 30-Areas medium to fully stocked with desirable trees and with less than 30 percent of the area controlled by other trees and/or inhibiting vegetation or surface conditions that will prevent occupancy by desirable trees.

Class 40-Areas medium to fully stocked with desirable trees and with 30 percent or more of the area controlled by other trees, or conditions that ordinarily prevent occupancy by desirable trees, or both.

Class 50-Areas poorly stocked with desirable trees, but fully stocked with growing-stock trees.

Class 60-Areas poorly stocked with desirable trees, but with medium to full stocking of growing-stock trees.

Class 70-Areas nonstocked or poorly stocked with desirable trees, and poorly stocked with growing-stock trees.

Class 80-Low-risk old-growth stands.

Class 90-High-risk old-growth stands.

Nonstocked-Areas less than 10 percent stocked with growing-stock trees.
Basal area-The cross-sectional area of a tree expressed in square feet. For timber species the calculation is based on diameter at breast height (d.b.h.); for woodland species it is based on diameter at root collar (d.r.c.).

Christmas tree grade-Pinyon species are classified as Christmas trees using the following guidelines:

Premium-Excellent conical form with no gaps in branches and a straight bole.

Standard-Good conical form with small gaps in branches and bole slightly malformed.

Utility-Conical in form with branches missing and bole bent or malformed.

Cull-Not meeting one of the above classifications or over 12 feet in height.

Cord-A pile of stacked wood equivalent to 128 cubic feet of wood and air space having standard dimensions of 4 by 4 by 8 feet.

Cull trees-Live trees that are unmerchantable now or prospectively (see Rough tree and Rotten tree).

Cull volume-Portions of a tree's volume that are not usable for wood products because of rot, missing or dead material, or other cubic-foot defect.

Deferred forest land-Forest lands within the National Forest System that are under study for possible inclusion in the Wilderness System.

Desirable trees - Growing-stock trees (1) having no serious defect in quality to limit present or prospective use for timber products, (2) of relatively high vigor, and (3) containing no pathogens that may result in death or serious deterioration within the next decade.

Diameter at breast height (d.b.h.)-Diameter of the stem measured at 4.5 feet above the ground.

Diameter at root collar (d.r.c.)-Diameter equivalent at the point nearest the ground line that represents the basal area of the tree stem or stems.

Diameter classes - Tree diameters, either d.b.h. or d.r.c., grouped into 2 -inch classes labeled by the midpoint of the class.

Farmer/rancher-owned lands-Lands owned by a person who operates a farm or a ranch and who either does the work or directly supervises the work.

Forest industry lands - Lands owned by companies or individuals operating a primary wood-processing plant.

Forest land-Land at least 10 percent stocked by forest trees of any size, including land that formerly had such tree cover and that will be naturally or artificially regenerated. The minimum area for classification of forest land is 1 acre. Roadside, streamside, and 
shelterbelt strips of timber must have a crown width at least 120 feet wide to qualify as forest land. Unimproved roads and trails, streams, and clearings in forest areas are classified as forest if less than 120 feet wide.

Forest trees-Woody plants having a well-developed stem or stems, usually more than 12 feet in height at maturity, with a generally well-defined crown.

Forest type-A classification of forest land based upon and named for the tree species presently forming a plurality of live-tree stocking.

Gross annual growth-The average annual increase in the net volume of trees during a specified period.

Growing-stock trees-Live sawtimber trees, poletimber trees, saplings, and seedlings of timber species meeting specified standards of quality and vigor; excludes cull trees.

Growing-stock volume-Net cubic-foot volume in live poletimber-size and sawtimber-size growing-stock trees from a 1 -foot stump to a minimum 4-inch top (of central stem) outside bark or to the point where the central stem breaks in to limbs.

Growth-See definition for Net annual growth.

Hardwood trees-Dicotyledonous trees, usually broadleaved and deciduous.

High-risk old-growth stands-Timber stands over 100 years old in which the majority of the trees are not expected to survive more than 10 years.

Indian lands-Indian lands held in trust by the Federal Government.

Industrial wood-All commercial roundwood products except fuel wood.

Land area-The area of dry land and land temporarily or partially covered by water such as marshes, swamps, and river flood plains, streams, sloughs, estuaries, and canals less than 120 feet wide; and lakes, reservoirs, and ponds less than 1 acre in size.

Logging residues-The unused portions of growing-stock trees cut or killed by logging.

Low-risk old-growth stands-Timber stands over 100 years old in which the majority of the trees are expected to survive more than 10 years.

Miscellaneous Federal lands-Lands administered by Federal agencies other than the U.S. Department of Agriculture, Forest Service or U.S. Department of the Interior, Bureau of Land Management.

Mortality-The net volume of growing-stock trees that have died from natural causes during a specified period.
National Forest lands-Public lands administered by the U.S. Department of Agriculture, Forest Service.

National Resource lands-Public lands administered by the U.S. Department of the Interior, Bureau of Land Management.

Net annual growth-Gross annual growth minus average annual mortality.

Net dead volume-Total net volume of dead trees plus the net volume of dead material in live trees.

Net volume in board feet-The gross board-foot volume in the sawlog portion of growing-stock trees, less deductions for cull volume.

Net volume in cubic feet-Gross cubic-foot volume in the merchantable portion of trees less deductions for cull volume. For timber species, volume is computed for the merchantable stem from a 1 -foot stump to a minimum 4-inch top diameter outside bark (d.o.b.), or to the point where the central stem breaks into limbs. For woodland species, volume is computed outside bark (o.b.) for all woody material above d.r.c. that is larger than 1.5 inches d.o.b.

Nonforest land_Land that does not currently qualify as forest land.

Nonindustrial private-All private ownerships except forest industry.

Nonstocked areas-Forest land less than 10 percent stocked with live trees.

Old-growth stands -Stands of timber species over 100 years old.

Other private land-Privately owned land other than forest industry or farmer-owned.

Other public land-Public land administered by agencies other than the U.S. Department of Agriculture, Forest Service.

Other removals - The net volume of growing-stock trees removed from the inventory by cultural operations such as timber-stand improvement, by land clearing, and by changes in land use, such as a shift to wilderness.

Poletimber stands-Stands at least 10 percent stocked with growing-stock trees, in which half or more of the stocking is sawtimber or poletimber trees or both, with poletimber stocking exceeding that of sawtimber (see definition for Stocking).

Poletimber trees-Live trees of timber species at least 5 inches d.b.h. but smaller than sawtimber size.

Posts-Juniper and oak species are evaluated for post potential using the following criteria: 
Line post-A 7-foot minimum length with 5 to 7 inches diameter at the butt, 2.5-inch minimum small end diameter, and reasonably straight and solid.

Corner post-An 8-foot minimum length with 7 to 9 inches diameter at the butt, 2.5 -inch minimum small end diameter, and reasonably straight and solid.

Potential growth-The average net annual cubic-foot growth per acre at culmination of mean annual growth attainable in fully stocked natural stands.

Primary wood-processing plants-Plants using roundwood products such as sawlogs, pulpwood bolts, veneer logs, and so forth.

Productivity class-A classification of forest land that reflects biological potential. For timberland the potential net annual growth at culmination of mean annual increment in fully stocked natural stands is the index used. For woodland, characteristics that affect the land's ability to produce wood, such as soil depth and aspect, are used. Furthermore, woodland is classified as high site where sustained wood production is likely, or low site where the continuous production of wood is unlikely.

Removals-The net volume of growing-stock trees removed from the inventory by harvesting, cultural operations, land clearings, or changes in land use.

Reserved forest land-Forest land withdrawn from tree utilization through statute or administrative designation.

Residues:

Coarse residues-Plant residues suitable for chipping, such as slabs, edgings, and ends.

Fine residues-Plant residues not suitable for chipping, such as sawdust, shavings, and veneer clippings. Plant residues-Wood materials from primary manufacturing plants that are not used for any product.

Rotten tree-A live poletimber or sawtimber tree with more than 67 percent of its total volume cull (cubic-foot), and with more than half of the cull volume attributable to rotten or missing material.

Rough tree-A live poletimber or sawtimber tree with more than 67 percent of its total volume cull (cubic-foot), and with less than half of the cull volume attributable to rotten or missing material.

Roundwood-Logs, bolts, or other round sections cut from trees.

Salvable dead trees - Standing or down dead trees that are currently merchantable by regional standards.

Saplings-Live trees of timber species 1 to 4.9 inches d.b.h., or woodland species 1 to 2.9 inches d.r.c.
Sapling and seedling stands-Timberland stands at least 10 percent stocked on which more than half of the stocking is saplings or seedlings or both.

Sawlog portion-That part of the bole of sawtimber trees between a 1 -foot stump and the sawlog top.

Sawlog top-The point on the bole of sawtimber trees above which a sawlog cannot be produced. The minimum sawlog top is 7 inches d.o.b. for softwoods and 9 inches d.o.b. for hardwoods.

Sawtimber stands-Stands at least 10 percent stocked with growing-stock trees, with half or more of total stocking in sawtimber or poletimber trees, and with sawtimber stocking at least equal to poletimber stocking.

Sawtimber trees-Live trees of timber species meeting regional size and defect specifications. Softwood trees must be at least 9 inches d.b.h. and hardwood trees 11 inches d.b.h.

Sawtimber volume-Net volume in board feet of the sawlog portion of live sawtimber trees.

Seedlings-Established live trees of timber species less than 1 inch d.b.h. or woodland species less than 1 inch d.r.c.

Softwood trees-Monocotyledonous trees, usually evergreen, having needle or scalelike leaves.

Standard error-An expression of the degree of confidence that can be placed on an estimated total or average obtained by statistical sampling methods. Standard errors do not include technique errors that could occur in photo classification of areas, field measurements, or compilation of data.

Stand-size classes-A classification of forest land based on the predominant size of trees present (see Sawtimber stands, Poletimber stands, and Sapling and seedling stands).

State, county, and municipal lands-Lands administered by States, counties, and local public agencies, or lands leased by these governmental units for more than 50 years.

Stocking-An expression of the extent to which growing space is effectively utilized by present or potential growing-stock trees of timber species.

Timberland-Forest land where timber species make up at least 10 percent stocking.

Timber species-Tree species traditionally used for industrial wood products.In the Rocky Mountain States, these include aspen and cottonwood hardwood species and all softwood species except pinyon and juniper. 
Timber stand improvement-Treatments such as thinning, pruning, release cutting, girdling, weeding, or poisoning of unwanted trees aimed at improving growing conditions for the remaining trees.

Upper-stem portion-That part of the main stem or fork of sawtimber trees above the sawlog top to a minimum top diameter of 4 inches outside bark or to the point where the main stem or fork breaks into limbs.

Water-Streams, sloughs, estuaries, and canals more than 120 feet wide, and lakes, reservoirs, and ponds more than 1 acre in size at mean high water level.

Wilderness-An area of undeveloped land currently included in the Wilderness System, managed so as to preserve its natural conditions and retain its primeval character and influence.

Woodland-Forest land where timber species make up less than 10 percent stocking.

Woodland species-Tree species not usually converted into industrial wood products. Common uses are fuelwood, fenceposts, and Christmas trees.

\section{REFERENCES}

Chojnacky, David C. 1985. Pinyon-juniper volume equations for the central Rocky Mountain States. Res. Pap. INT-339. Ogden, UT: U.S. Department of Agriculture, Forest Service, Intermountain Forest and Range Experiment Station. 27 p.

Edminster, Carleton B.; Mowrer, H. Todd; Hinds, Thomas E. 1981. Volume tables and point-sampling factor for aspen in Colorado. Res. Pap. RM-232. Fort Collins, CO: U.S. Department of Agriculture, Forest Service, Rocky Mountain Forest and Range Experiment Station. 16 p.

Edminster, Carleton B.; Beeson, Robert T.; Metcalf, Gary E. 1980. Volume tables and point-sampling factors for ponderosa pine in the Front Range of Colorado. Res. Pap. RM-218. Fort Collins, CO: U.S. Department of Agriculture, Forest Service, Rocky Mountain Forest and Range Experiment Station. $14 \mathrm{p}$.

Kemp, Paul D. 1958. Volume tables. Unpublished report on file at: U.S. Department of Agriculture, Forest Service, Intermountain Research Station, Ogden, UT.

McLain, William H. 1987. Wyoming and western South Dakota-timber production and mill residues, 1983. Resour. Bull. INT-45. Ogden, UT: U.S. Department of Agriculture, Forest Survey, Intermountain Research Station. $32 \mathrm{p}$.

Meyers, Clifford A. 1964. Volume tables and pointsampling factors for lodgepole pine in Colorado and Wyoming. Res. Pap. RM-6. Fort Collins, CO: U.S. Department of Agriculture, Forest Service, Rocky Mountain Forest and Range Experiment Station. 16 p.

Meyers, Clifford A.; Edminster, Carleton B. 1972. Volume tables and point-sampling factors for Engelmann spruce in Colorado and Wyoming. Res. Pap. RM-95. Fort Collins, CO: U.S. Department of Agriculture, Forest Service, Rocky Mountain Forest and Range Experiment Station. 23 p. 
Table 1--Total 1and and water area by ownership class in central-southeastern Wyoming, 1984

\begin{tabular}{|c|c|}
\hline Ownership class & Area \\
\hline & - - Acres - \\
\hline \multicolumn{2}{|l|}{ Land: } \\
\hline $\begin{array}{l}\text { Public: } \\
\text { National Forest }\end{array}$ & $2,387,826$ \\
\hline $\begin{array}{l}\text { Other public: } \\
\text { Bureau of Land Management } \\
\text { National Parks l } \\
\text { Miscellaneous Federal } \\
\text { State } \\
\text { County and municipal }\end{array}$ & $\begin{array}{r}6,851,719 \\
23,163 \\
55,634 \\
2,543,546 \\
2,717 \\
\end{array}$ \\
\hline Total other public & $9,476,779$ \\
\hline Total public & $11,864,605$ \\
\hline Private & $15,925,687$ \\
\hline Total land area & $27,790,292$ \\
\hline Census water & 161,120 \\
\hline Total land and water ${ }^{2}$ & $27,951,412$ \\
\hline
\end{tabular}

INot included with miscellaneous Federal, a component of other public, for purpose of clarity. These lands, and other reserved lands, are included in tables $1,2,4$, and 5 on ly.

2 U.S. Department of Commerce, Bureau of Census. Area measurement reports, GE-20 No. 1, 22p., 1970, updated to account for changes in inland water estimates obtained from the USDA, So il Conservation Service National Resource Inventory, $198 \hat{c}$. 
Table 2--Area of forest land outside National Forests with percent standard error in central-southeastern Wyoming, 1984

\begin{tabular}{|c|c|c|c|c|c|c|}
\hline \multirow{2}{*}{ I tem } & \multicolumn{2}{|c|}{ Softwoods } & \multicolumn{2}{|c|}{ Hardwoods } & \multicolumn{2}{|c|}{ All types } \\
\hline & Acres & $\begin{array}{l}\text { Percent } \\
\text { standard } \\
\text { error }\end{array}$ & Acres & $\begin{array}{l}\text { Percent } \\
\text { standard } \\
\text { error }\end{array}$ & Acres & $\begin{array}{l}\text { Percent } \\
\text { standard } \\
\text { error }\end{array}$ \\
\hline Timber land & 900,176 & \pm 5.2 & 153,825 & \pm 20.8 & $1,054,001$ & \pm 4.0 \\
\hline Woodland & 253,375 & \pm 16.6 & 27,689 & \pm 57.9 & 281,064 & \pm 15.8 \\
\hline $\begin{array}{l}\text { Reserved forest land: } 1 \\
\text { Timberland } \\
\text { Woodland }\end{array}$ & $\begin{array}{l}2,238 \\
3,200 \\
\end{array}$ & & -- & & $\begin{array}{l}2,238 \\
3,200 \\
\end{array}$ & \\
\hline Total forest land ${ }^{2}$ & $1,158,989$ & & 181,514 & & $1,340,503$ & \\
\hline
\end{tabular}

IReserved land areas are estimated from aerial photos without field verification; therefore, standard errors are not calculated.

20 this and all following tables, totals may vary due to rounding.

Table 3--Net volume, net annual growth, and annual mortality of growing stock and sawtimber on timberland outside National Forests with percent standard error in central-southeastern Wyoming

\begin{tabular}{|c|c|c|c|c|c|c|}
\hline \multirow{2}{*}{ Item } & \multicolumn{2}{|c|}{ Sof twoods } & \multicolumn{2}{|c|}{ Hardwoods } & \multicolumn{2}{|c|}{ All species } \\
\hline & Volume & $\begin{array}{l}\text { Percent } \\
\text { standard } \\
\text { error }\end{array}$ & Volume & $\begin{array}{l}\text { Percent } \\
\text { standard } \\
\text { error }\end{array}$ & Volume & $\begin{array}{l}\text { Percent } \\
\text { standard } \\
\text { error }\end{array}$ \\
\hline $\begin{array}{l}\text { Net volume, } 1984 \text { : } \\
\text { Growing stock (M cubic feet) } \\
\text { Sawtimber ( } M \text { board feet) } \\
\text { Sawtimber }{ }^{2} \text { ( } M \text { board feet) }\end{array}$ & $\begin{array}{r}867,820 \\
2,783,304 \\
2,371,262 \\
\end{array}$ & $\begin{array}{l} \pm 11.9 \\
\pm 14.4 \\
\pm 14.6 \\
\end{array}$ & $\begin{array}{l}128,180 \\
239,204 \\
206,091 \\
\end{array}$ & $\begin{array}{l} \pm 28.3 \\
\pm 35.4 \\
\pm 35.8 \\
\end{array}$ & $\begin{array}{r}996,000 \\
3,022,508 \\
2,577,353 \\
\end{array}$ & $\begin{array}{l} \pm 10.8 \\
\pm 13.4 \\
\pm 13.5 \\
\end{array}$ \\
\hline $\begin{array}{l}\text { Net annual growth, 1983: } \\
\text { Growing stock'( } M \text { cubic feet) } \\
\text { Sawtimber ( } M \text { board feet) } \\
\text { Sawtimber }{ }^{2}(M \text { board feet) }\end{array}$ & $\begin{array}{l}18,500 \\
72,045 \\
62,197 \\
\end{array}$ & $\begin{array}{l} \pm 13.4 \\
\pm 17.9 \\
\pm 17.7 \\
\end{array}$ & $\begin{array}{l}1,962 \\
2,998 \\
2,656 \\
\end{array}$ & $\begin{array}{l} \pm 55.6 \\
\pm 90.0 \\
\pm 89.2 \\
\end{array}$ & $\begin{array}{l}20,462 \\
75,043 \\
64,853 \\
\end{array}$ & $\begin{array}{l} \pm 13.3 \\
\pm 17.5 \\
\pm 17.3 \\
\end{array}$ \\
\hline $\begin{array}{l}\text { Annual mortality, 1983: } \\
\text { Growing stock (M cubic feet) } \\
\text { Sawtimber ( } M \text { board feet) } \\
\text { Sawtimber }{ }^{2} \text { ( } M \text { board feet) }\end{array}$ & $\begin{array}{l}2,381 \\
6,914 \\
5,894\end{array}$ & $\begin{array}{l} \pm 37.1 \\
\pm 55.9 \\
\pm 56.1\end{array}$ & $\begin{array}{l}1,729 \\
2,518 \\
2,166\end{array}$ & $\begin{array}{l} \pm 53.3 \\
\pm 73.0 \\
\pm 73.0\end{array}$ & $\begin{array}{l}4,110 \\
9,432 \\
8,060\end{array}$ & $\begin{array}{l} \pm 30.6 \\
\pm 45.2 \\
\pm 45.2\end{array}$ \\
\hline
\end{tabular}

I International t-inch rule.

2scribner rule. 
Table 4--Total land area outside National Forests by major land class and ownership class in central-southeastern Wyoming, 1984

\begin{tabular}{|c|c|c|c|}
\hline \multirow{2}{*}{ Land class } & \multicolumn{2}{|c|}{ Ownership class } & \multirow[b]{2}{*}{ Total } \\
\hline & $\begin{array}{l}\text { Other } \\
\text { public }\end{array}$ & Private & \\
\hline & $-\cdot-\cdot$ & - Acres - & $-\cdots$ \\
\hline $\begin{array}{l}\text { Timberland: } \\
\text { Reserved } \\
\text { Nonreserved }\end{array}$ & $\begin{array}{r}2,238 \\
361,427 \\
\end{array}$ & 692,574 & $\begin{array}{r}2,238 \\
1,054,001 \\
\end{array}$ \\
\hline Total & 363,665 & 692,574 & $1,056,239$ \\
\hline $\begin{array}{l}\text { Woodland: } \\
\text { Reserved } \\
\text { Nonreserved }\end{array}$ & $\begin{array}{r}3,200 \\
190,807 \\
\end{array}$ & 90,257 & $\begin{array}{r}3,200 \\
281,064 \\
\end{array}$ \\
\hline Total & 194,007 & 90,257 & 284,264 \\
\hline $\begin{array}{l}\text { Total forest land: } \\
\text { Reserved } \\
\text { Nonreserved }\end{array}$ & $\begin{array}{r}5,438 \\
552,234 \\
\end{array}$ & 782.831 & $\begin{array}{r}5,438 \\
1,335,065 \\
\end{array}$ \\
\hline Total & 557,672 & 782,831 & $1,340,503$ \\
\hline Nonforest 1 and & $8,919,946$ & $15,142,017$ & $24,061,963$ \\
\hline Total land area & $9,477,618$ & $15,924,848$ & $25,402,466$ \\
\hline
\end{tabular}

Table 5--Area of forest land outside National Forests by forest type, ownership class, and land class in central-southeastern Wyoming, 1984

\begin{tabular}{|c|c|c|c|c|c|c|c|}
\hline \multirow{3}{*}{ Forest type } & \multicolumn{4}{|c|}{ Ownership class and land class } & \multirow{2}{*}{\multicolumn{3}{|c|}{ All owners }} \\
\hline & \multicolumn{2}{|c|}{ Other public } & \multicolumn{2}{|c|}{ Private } & & & \\
\hline & Reserved & Nonreserved & Reserved & Nonreserved & Reserved & Nonreserved & Total \\
\hline & ---- & $\ldots$ & $-\cdots$ & Acres - - & $--\cdot-$ & $\cdots \cdots$ & \\
\hline $\begin{array}{l}\text { Douglas-fir } \\
\text { Ponderosa pine } \\
\text { Lodgepole pine } \\
\text { Limber pine } \\
\text { Spruce-fir } \\
\text { Spruce } \\
\text { Aspen } \\
\text { Cottonwood }\end{array}$ & $\begin{array}{r}-- \\
-- \\
-- \\
-- \\
-- \\
-- \\
-- \\
2,238\end{array}$ & $\begin{array}{r}21,111 \\
143,008 \\
56,713 \\
84,074 \\
26,086 \\
6,959 \\
23,476 \\
\end{array}$ & $\begin{array}{l}-- \\
-- \\
-- \\
-- \\
-- \\
-- \\
-- \\
--\end{array}$ & $\begin{array}{r}16,015 \\
362,398 \\
79,928 \\
69,749 \\
27,454 \\
6,681 \\
69,161 \\
61,188 \\
\end{array}$ & $\begin{array}{r}-- \\
-- \\
-- \\
-- \\
-- \\
-- \\
- \\
2,238\end{array}$ & $\begin{array}{r}37,126 \\
505,406 \\
136,641 \\
153,823 \\
53,540 \\
13,640 \\
92,637 \\
61,188 \\
\end{array}$ & $\begin{array}{r}37,126 \\
505,406 \\
136,641 \\
153,823 \\
53,540 \\
13,640 \\
92,637 \\
63,426 \\
\end{array}$ \\
\hline Total timberland & 2,238 & 361,427 & - & 692,574 & 2,238 & $1,054,001$ & $1,056,239$ \\
\hline $\begin{array}{l}\text { Juniper } \\
\text { Mountain brush } \\
\text { Riparian }\end{array}$ & $\begin{array}{r}3,200 \\
-- \\
-- \\
\end{array}$ & $\begin{array}{r}183,175 \\
7,632 \\
-- \\
\end{array}$ & $\begin{array}{l}-- \\
-- \\
--\end{array}$ & $\begin{array}{r}70,200 \\
-- \\
20,057 \\
\end{array}$ & $\begin{array}{r}3,200 \\
-- \\
-- \\
\end{array}$ & $\begin{array}{r}253,375 \\
7,632 \\
20,057 \\
\end{array}$ & $\begin{array}{r}256,575 \\
7,632 \\
20,057 \\
\end{array}$ \\
\hline Total woodland & 3,200 & 190,807 & -- & 90,257 & 3,200 & 281,064 & 284,264 \\
\hline Total all types & 5,438 & 552,234 & -- & 782,831 & 5,438 & $1,335,065$ & $1,340,503$ \\
\hline
\end{tabular}


Table 6--Cubic feet of net volume in trees on forest land outside National Forests by species and ownership class in central-southeastern Wyoming, 1984

\begin{tabular}{|c|c|c|c|}
\hline \multirow{2}{*}{ Species } & \multicolumn{2}{|c|}{ Ownership class } & \multirow[b]{2}{*}{ Total } \\
\hline & $\begin{array}{l}\text { Other } \\
\text { public }\end{array}$ & Private & \\
\hline & $\cdots$ & and cubic & eet $-\cdots$ \\
\hline $\begin{array}{l}\text { Douglas-fir } \\
\text { Ponderosa pine } \\
\text { Lodgepole pine } \\
\text { Limber pine } \\
\text { Subalpine fir } \\
\text { Engelmann spruce } \\
\text { Aspen } \\
\text { Cottonwood }\end{array}$ & $\begin{array}{r}41,637 \\
95,994 \\
101,527 \\
33,006 \\
39,667 \\
42,557 \\
32,322 \\
-- \\
\end{array}$ & $\begin{array}{r}48,180 \\
232,085 \\
138,505 \\
49,970 \\
34,705 \\
13,503 \\
69,128 \\
26,731 \\
\end{array}$ & $\begin{array}{r}89,817 \\
328,079 \\
240,032 \\
82,976 \\
74,372 \\
56,060 \\
101,450 \\
26,731 \\
\end{array}$ \\
\hline Total timberland species & 386,710 & 612,807 & 999,517 \\
\hline $\begin{array}{l}\text { Woodland softwoods } \\
\text { Woodland hardwoods }\end{array}$ & $\begin{array}{r}45,115 \\
897 \\
\end{array}$ & $\begin{array}{l}26,927 \\
61,757 \\
\end{array}$ & $\begin{array}{l}72,042 \\
62,654 \\
\end{array}$ \\
\hline Total woodland species & 46,012 & 88,684 & 134,696 \\
\hline Total all species & 432,722 & 701,491 & $1,134,213$ \\
\hline
\end{tabular}

Table 7--Cubic feet of net annual growth in trees on forest land outside National Forests by species and ownership class in central-southeastern Wyoming, 1983

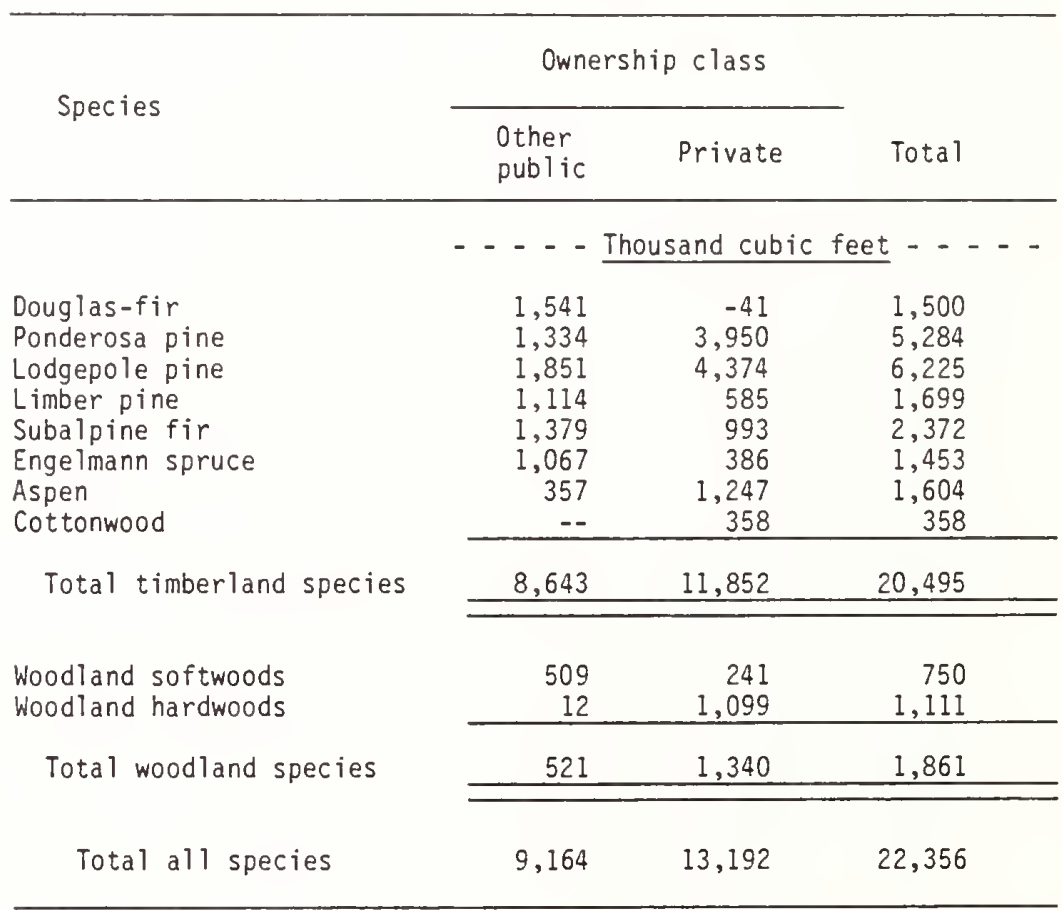


Table 8--Cubic feet of annual mortality in trees on forest land outside National Forests by species and ownership class in central-southeastern Wyoming, 1983

\begin{tabular}{|c|c|c|c|}
\hline \multirow{2}{*}{ Species } & \multicolumn{2}{|c|}{ Ownership class } & \multirow[b]{2}{*}{ Total } \\
\hline & $\begin{array}{l}\text { Other } \\
\text { public }\end{array}$ & Private & \\
\hline & $--\cdots-I$ & sand cubi & $t-\cdots$ \\
\hline $\begin{array}{l}\text { Douglas-fir } \\
\text { Ponderosa pine } \\
\text { Lodgepole pine } \\
\text { Limber pine } \\
\text { Subalpine fir } \\
\text { Engelmann spruce } \\
\text { Aspen } \\
\text { Cottonwood }\end{array}$ & $\begin{array}{r}-- \\
689 \\
-- \\
493 \\
-- \\
-- \\
528 \\
--\end{array}$ & $\begin{array}{r}564 \\
254 \\
149 \\
156 \\
76 \\
-- \\
848 \\
353 \\
\end{array}$ & $\begin{array}{r}564 \\
943 \\
149 \\
649 \\
76 \\
-- \\
1,376 \\
353 \\
\end{array}$ \\
\hline Total timberland species & 1,710 & 2,400 & 4,110 \\
\hline $\begin{array}{l}\text { Woodland softwoods } \\
\text { Woodland hardwoods }\end{array}$ & -- & $\begin{array}{l}86 \\
-- \\
\end{array}$ & $\begin{array}{l}86 \\
-- \\
\end{array}$ \\
\hline Total woodland species & -- & 86 & 86 \\
\hline Total all species & 1,710 & 2,486 & 4,196 \\
\hline
\end{tabular}


Table 9--Area of timberland outside National Forests by forest type, stand-size class, and productivity class in central-southeastern Wyoming, 1984

Forest type and

stand-size class

\begin{tabular}{cccc}
\multicolumn{3}{c}{ Productivity class } & $\begin{array}{l}\text { Total } \\
\text { acres }\end{array}$
\end{tabular}

\begin{tabular}{|c|c|c|c|c|c|}
\hline & --- & -- & Acres - & $-\cdots$ & $-\cdots$ \\
\hline $\begin{array}{l}\text { Douglas-fir: } \\
\text { Sawtimber } \\
\text { Poletimber } \\
\text { Sapling and seedling } \\
\text { Nonstocked }\end{array}$ & $\begin{array}{l}-- \\
-- \\
-- \\
--\end{array}$ & $\begin{array}{r}-- \\
-- \\
6,959 \\
-- \\
\end{array}$ & $\begin{array}{r}22,974 \\
7,193 \\
-- \\
-- \\
\end{array}$ & $\begin{array}{l}-- \\
-- \\
-- \\
--\end{array}$ & $\begin{array}{r}22,974 \\
7,193 \\
6,959 \\
-- \\
\end{array}$ \\
\hline Total & -- & 6,959 & 30,167 & -- & 37,126 \\
\hline $\begin{array}{l}\text { Ponderosa pine: } \\
\text { Sawtimber } \\
\text { Poletimber } \\
\text { Sapling and seedling } \\
\text { Nonstocked }\end{array}$ & $\begin{array}{l}-- \\
-- \\
-- \\
--\end{array}$ & $\begin{array}{l}-- \\
-- \\
-- \\
-- \\
\end{array}$ & $\begin{array}{r}285,002 \\
38,982 \\
25,599 \\
94,925 \\
\end{array}$ & $\begin{array}{r}31,377 \\
12,492 \\
-- \\
17,029 \\
\end{array}$ & $\begin{array}{r}316,379 \\
51,474 \\
25,599 \\
111,954 \\
\end{array}$ \\
\hline Total & -- & -- & 444,508 & 60,898 & 505,406 \\
\hline $\begin{array}{l}\text { Lodgepole pine: } \\
\text { Sawtimber } \\
\text { Poletimber } \\
\text { Sapling and seedling } \\
\text { Nonstocked }\end{array}$ & $\begin{array}{l}-- \\
-- \\
-- \\
-- \\
\end{array}$ & $\begin{array}{r}20,320 \\
6,440 \\
8,121 \\
-. \\
\end{array}$ & $\begin{array}{r}14,132 \\
73,068 \\
6,439 \\
8,121 \\
\end{array}$ & $\begin{array}{l}-- \\
-- \\
-- \\
--\end{array}$ & $\begin{array}{r}34,452 \\
79,508 \\
14,560 \\
8,121 \\
\end{array}$ \\
\hline Total & -- & 34,881 & 101,760 & -- & 136,641 \\
\hline $\begin{array}{l}\text { Limber pine: } \\
\text { Sawtimber } \\
\text { Poletimber } \\
\text { Sapling and seedling } \\
\text { Nonstocked }\end{array}$ & $\begin{array}{l}-- \\
-- \\
-- \\
--\end{array}$ & $\begin{array}{r}18,113 \\
-- \\
-- \\
-- \\
\end{array}$ & $\begin{array}{r}26,964 \\
41,167 \\
6,680 \\
3,630 \\
\end{array}$ & $\begin{array}{r}11,999 \\
13,120 \\
-- \\
32,150 \\
\end{array}$ & $\begin{array}{r}57,076 \\
54,287 \\
6,680 \\
35,780 \\
\end{array}$ \\
\hline Total & -- & 18,113 & 78,441 & 57,269 & 153,823 \\
\hline $\begin{array}{l}\text { Spruce-fir: } \\
\text { Sawtimber } \\
\text { Poletimber } \\
\text { Sapling and seedling } \\
\text { Nonstocked }\end{array}$ & $\begin{array}{r}19,647 \\
\ldots- \\
\ldots- \\
- \\
\end{array}$ & $\begin{array}{r}21,488 \\
6,681 \\
5,724 \\
-. \\
\end{array}$ & $\begin{array}{l}-- \\
-- \\
-- \\
-- \\
\end{array}$ & $\begin{array}{l}-- \\
-- \\
-- \\
-\end{array}$ & $\begin{array}{r}41,135 \\
6,681 \\
5,724 \\
-. \\
\end{array}$ \\
\hline Total & 19,647 & 33,893 & -- & $=-$ & 53,540 \\
\hline
\end{tabular}

(con.) 
Table 9 (con.)

Forest type and stand-size class

\begin{tabular}{lllll}
\multicolumn{3}{c}{ Productivity class } & Total \\
$85-119$ & $50-84$ & $20-49$ & $0-19$ & acres
\end{tabular}

\begin{tabular}{|c|c|c|c|c|c|}
\hline & $-\cdots$ & $-\cdots$ & Acres - & $-\cdots$ & $\cdots$ \\
\hline $\begin{array}{l}\text { Spruce: } \\
\text { Sawtimber } \\
\text { Poletimber } \\
\text { Sapling and seedling } \\
\text { Nonstocked }\end{array}$ & $\begin{array}{l}-- \\
-- \\
-- \\
-- \\
\end{array}$ & $\begin{array}{r}13,640 \\
-- \\
-- \\
-- \\
\end{array}$ & $\begin{array}{l}-- \\
-- \\
-- \\
--\end{array}$ & $\begin{array}{l}-- \\
-- \\
-- \\
--\end{array}$ & $\begin{array}{r}13,640 \\
- \\
-- \\
- \\
\end{array}$ \\
\hline Total & -- & 13,640 & -- & -- & 13,640 \\
\hline $\begin{array}{l}\text { Aspen: } \\
\text { Sawtimber } \\
\text { Poletimber } \\
\text { Sapling and seedling } \\
\text { Nonstocked }\end{array}$ & $\begin{array}{l}-- \\
-- \\
-- \\
--\end{array}$ & $\begin{array}{r}14,688 \\
19,244 \\
6,440 \\
-- \\
\end{array}$ & $\begin{array}{r}-- \\
32,464 \\
19,801 \\
-\end{array}$ & $\begin{array}{l}-- \\
-- \\
--\end{array}$ & $\begin{array}{r}14,688 \\
51,708 \\
26,241 \\
--\end{array}$ \\
\hline Total & -- & 40,372 & 52,265 & -- & 92,637 \\
\hline $\begin{array}{l}\text { Cottonwood: } \\
\text { Sawtimber } \\
\text { Poletimber } \\
\text { Sapling and seedling } \\
\text { Nonstocked }\end{array}$ & $\begin{array}{r}9,021 \\
- \\
-- \\
20,043 \\
\end{array}$ & $\begin{array}{r}4,363 \\
-- \\
-- \\
8,452 \\
\end{array}$ & $\begin{array}{r}10,087 \\
-- \\
-- \\
9,222 \\
\end{array}$ & $\begin{array}{l}-- \\
-- \\
-- \\
-- \\
\end{array}$ & $\begin{array}{r}23,471 \\
- \\
-- \\
37,717 \\
\end{array}$ \\
\hline Total & 29,064 & 12,815 & 19,309 & -- & 61,188 \\
\hline $\begin{array}{l}\text { Total: } \\
\text { Sawtimber } \\
\text { Poletimber } \\
\text { Sapling and seedling } \\
\text { Nonstocked }\end{array}$ & $\begin{array}{r}28,668 \\
= \\
-- \\
20,043 \\
\end{array}$ & $\begin{array}{r}92,612 \\
32,365 \\
27,244 \\
8,452 \\
\end{array}$ & $\begin{array}{r}359,159 \\
192,874 \\
58,519 \\
115,898 \\
\end{array}$ & $\begin{array}{r}43,376 \\
25,612 \\
-- \\
49,179 \\
\end{array}$ & $\begin{array}{r}523,815 \\
250,851 \\
85,763 \\
193,572 \\
\end{array}$ \\
\hline Total & 48,711 & 160,673 & 726,450 & 118,167 & $1,054,001$ \\
\hline
\end{tabular}


Table 10--Area of other publicly owned timberland by forest type, stand-size class, and productivity class in central-southeastern Wyoming, 1984

Forest type and stand-size class

\begin{tabular}{lllll}
\multicolumn{3}{c}{ Productivity class } & $\begin{array}{l}\text { Total } \\
\text { acres }\end{array}$
\end{tabular}

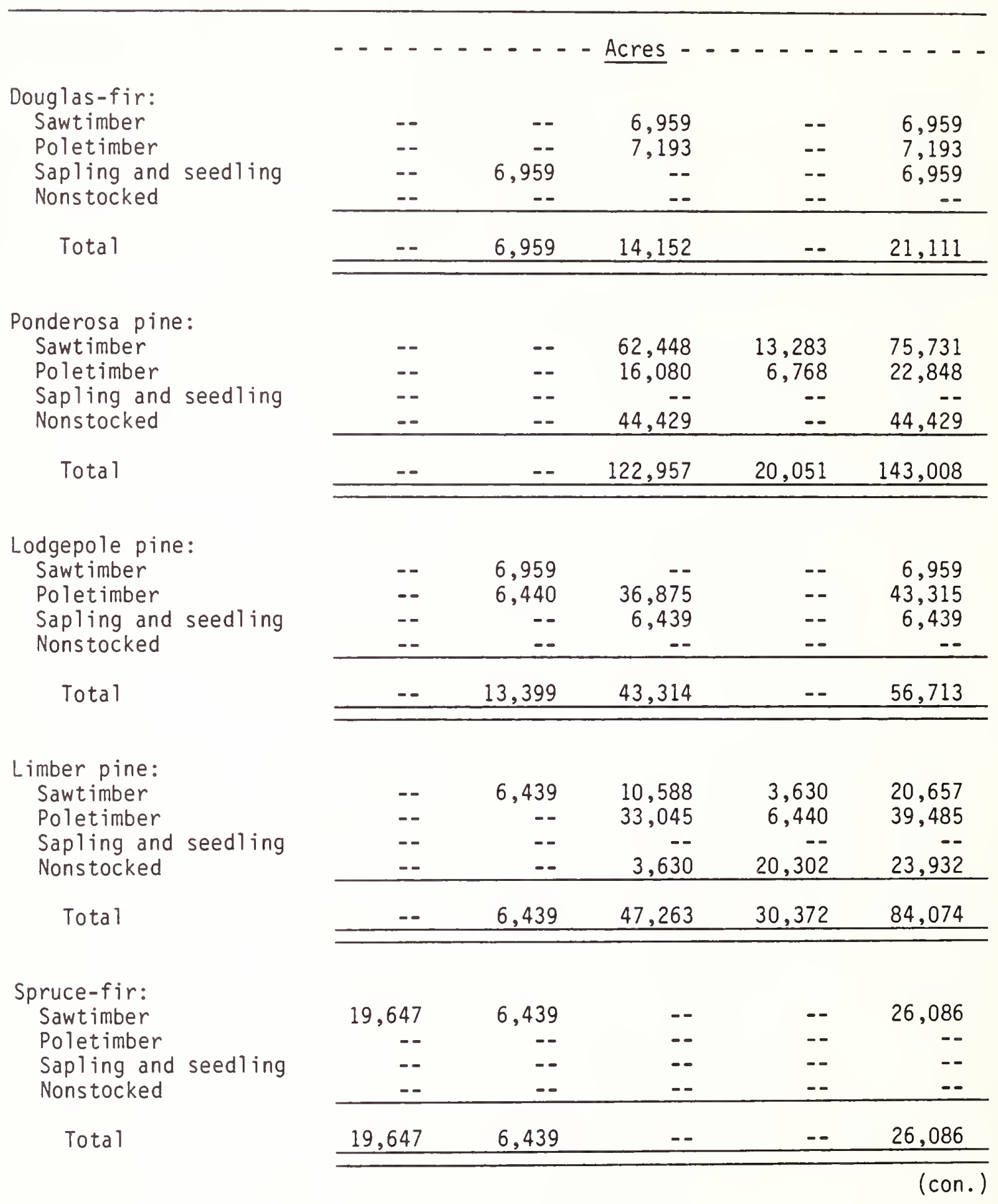


Table 10 (con.)

Forest type and stand-size class

\begin{tabular}{lllll}
\multicolumn{3}{c}{ Productivity class } & Total \\
$85-119$ & $50-84$ & $20-49$ & $0-19$ & acres
\end{tabular}

Spruce:

Sawtimber

Poletimber

Sapling and seedling Nonstocked

Total

Aspen:

Sawtimber

Poletimber

Sapling and seedling Nons tocked

Total

\begin{tabular}{rrrrr}
-- & 6,959 & -- & -- & 6,959 \\
-- & -- & -- & -- & -- \\
-- & -- & -- & -- & -- \\
-- & -- & -- & -- & -- \\
\hline-- & 6,959 & -- & -- & 6,959 \\
\hline
\end{tabular}

\begin{tabular}{rrrrr}
-- & -- & -- & -- & -- \\
-- & 6,439 & 4,157 & -- & 10,596 \\
-- & 6,440 & 6,440 & -- & 12,880 \\
-- & -- & -- & -- & -- \\
\hline-- & 12,879 & 10,597 & -- & 23,476 \\
\hline
\end{tabular}

Cottonwood:

Sawt imber

Poletimber

Sapling and seedling Nons tocked

Total

Total:

Sawtimber

Poletimber

Sapling and seedling

Nons tocked

\begin{tabular}{lllll}
-- & -- & -- & -- & -- \\
-- & -- & -- & -- & -- \\
-- & -- & -- & -- & -- \\
-- & -- & -- & -- & -- \\
\hline-- & -- & -- & -- & -- \\
\hline
\end{tabular}

Total

\begin{tabular}{rrrrr}
19,647 & 26,796 & 79,995 & 16,913 & 143,351 \\
-- & 12,879 & 97,350 & 13,208 & 123,437 \\
-- & 13,399 & 12,879 & -- & 26,278 \\
-- & -- & 48,059 & 20,302 & 68,361 \\
\hline 19,647 & 53,074 & 238,283 & 50,423 & 361,427
\end{tabular}


Table 11--Area of privately owned timberland by forest type, stand-size class, and productivity class in central-southeastern Wyoming, 1984

Forest type and stand-size class

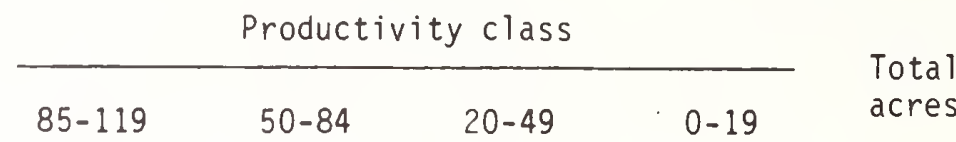

Douglas-fir:

Sawtimber

Poletimber

Sapling and seedling

Nons tocked

Total

Ponderosa pine:

Sawtimber

Poletimber

Sapling and seedling

Nons tocked

Total

\begin{tabular}{rrrrr}
-- & -- & 16,015 & -- & 16,015 \\
-- & -- & -- & -- & -- \\
-- & -- & -- & -- & -- \\
-- & -- & -- & -- & -- \\
\hline-- & -- & 16,015 & -- & 16,015 \\
\hline
\end{tabular}

\begin{tabular}{rrrrr}
-- & -- & 222,554 & 18,094 & 240,648 \\
-- & -- & 22,902 & 5,724 & 28,626 \\
-- & -- & 25,599 & -- & 25,599 \\
-- & -- & 50,496 & 17,029 & 67,525 \\
\hline & & & & \\
-- & -- & 321,551 & 40,847 & 362,398 \\
\hline
\end{tabular}

Lodgepole pine:

Sawtimber

Poletimber

Sapling and seedling

Nons tocked

Total

\begin{tabular}{rrrrr}
-- & 13,361 & 14,132 & -- & 27,493 \\
-- & -- & 36,193 & -- & 36,193 \\
-- & 8,121 & -- & -- & 8,121 \\
-- & -- & 8,121 & -- & 8,121 \\
\hline-- & 21,482 & 58,446 & -- & 79,928 \\
\hline
\end{tabular}

Limber pine:

Sawtimber

Poletimber

Sapling and seedling

Nons tocked

Total

\begin{tabular}{rrrrr}
-- & 11,674 & 16,376 & 8,369 & 36,419 \\
-- & -- & 8,122 & 6,680 & 14,802 \\
-- & -- & 6,680 & -- & 6,680 \\
-- & -- & -- & 11,848 & 11,848 \\
\hline-- & 11,674 & 31,178 & 26,897 & 69,749 \\
\hline
\end{tabular}

Spruce-fir:

Sawtimber

Poletimber

Sapling and seedling

Nons tocked

Total

\begin{tabular}{rrrrr}
-- & 15,049 & - & -- & 15,049 \\
-- & 6,681 & -- & -- & 6,681 \\
-- & 5,724 & -- & -- & 5,724 \\
-- & -- & -- & -- & -- \\
\hline & 27,454 & -- & -- & 27,454 \\
\hline
\end{tabular}


Table 11 (con.)

Forest type and stand-size class

\begin{tabular}{lllll}
\multicolumn{3}{c}{ Productivity class } & Total \\
& $50-84$ & $20-49$ & $0-19$ & acres
\end{tabular}

\begin{tabular}{|c|c|c|c|c|c|}
\hline & $-\cdots$ & $-\cdot-$ & Acres - & $-\cdot-$ & $-\cdots$ \\
\hline $\begin{array}{l}\text { Spruce: } \\
\text { Sawtimber } \\
\text { Poletimber } \\
\text { Sapling and seedling } \\
\text { Nonstocked }\end{array}$ & $\begin{array}{l}-- \\
-- \\
-- \\
-- \\
\end{array}$ & $\begin{array}{r}6,681 \\
-- \\
-- \\
-- \\
\end{array}$ & $\begin{array}{l}-- \\
-- \\
-- \\
--\end{array}$ & $\begin{array}{l}-- \\
-- \\
-- \\
-- \\
\end{array}$ & $\begin{array}{r}6,681 \\
-- \\
-- \\
-- \\
\end{array}$ \\
\hline Total & -- & 6,681 & -- & -- & 6,681 \\
\hline $\begin{array}{l}\text { Aspen: } \\
\text { Sawtimber } \\
\text { Poletimber } \\
\text { Sapling and seedling } \\
\text { Nonstocked }\end{array}$ & $\begin{array}{l}-- \\
-- \\
-- \\
-- \\
\end{array}$ & $\begin{array}{r}14,688 \\
12,805 \\
-- \\
-- \\
\end{array}$ & $\begin{array}{r}-- \\
28,307 \\
13,361 \\
-- \\
\end{array}$ & $\begin{array}{l}-- \\
-- \\
-- \\
--\end{array}$ & $\begin{array}{r}14,688 \\
41,112 \\
13,361 \\
--\end{array}$ \\
\hline Total & -- & 27,493 & 41,668 & - & 69,161 \\
\hline $\begin{array}{l}\text { Cottonwood: } \\
\text { Sawtimber } \\
\text { Poletimber } \\
\text { Sapling and seedling } \\
\text { Nonstocked }\end{array}$ & $\begin{array}{r}9,021 \\
-- \\
-- \\
20,043 \\
\end{array}$ & $\begin{array}{r}4,363 \\
-- \\
-- \\
8,452 \\
\end{array}$ & $\begin{array}{r}10,087 \\
-- \\
-- \\
9,222 \\
\end{array}$ & $\begin{array}{l}-- \\
-- \\
-- \\
--\end{array}$ & $\begin{array}{r}23,471 \\
-- \\
-- \\
37,717 \\
\end{array}$ \\
\hline Total & 29,064 & 12,815 & 19,309 & -- & 61,188 \\
\hline $\begin{array}{l}\text { Total: } \\
\text { Sawtimber } \\
\text { Poletimber } \\
\text { Sapling and seedling } \\
\text { Nonstocked }\end{array}$ & $\begin{array}{r}9,021 \\
-- \\
-- \\
20,043 \\
\end{array}$ & $\begin{array}{r}65,816 \\
19,486 \\
13,845 \\
8,452 \\
\end{array}$ & $\begin{array}{r}279,164 \\
95,524 \\
45,640 \\
67,839 \\
\end{array}$ & $\begin{array}{r}26,463 \\
12,404 \\
-- \\
28,877 \\
\end{array}$ & $\begin{array}{r}380,464 \\
127,414 \\
59,485 \\
125,211 \\
\end{array}$ \\
\hline Total & 29,064 & 107,599 & 488,167 & 67,744 & 692,574 \\
\hline
\end{tabular}




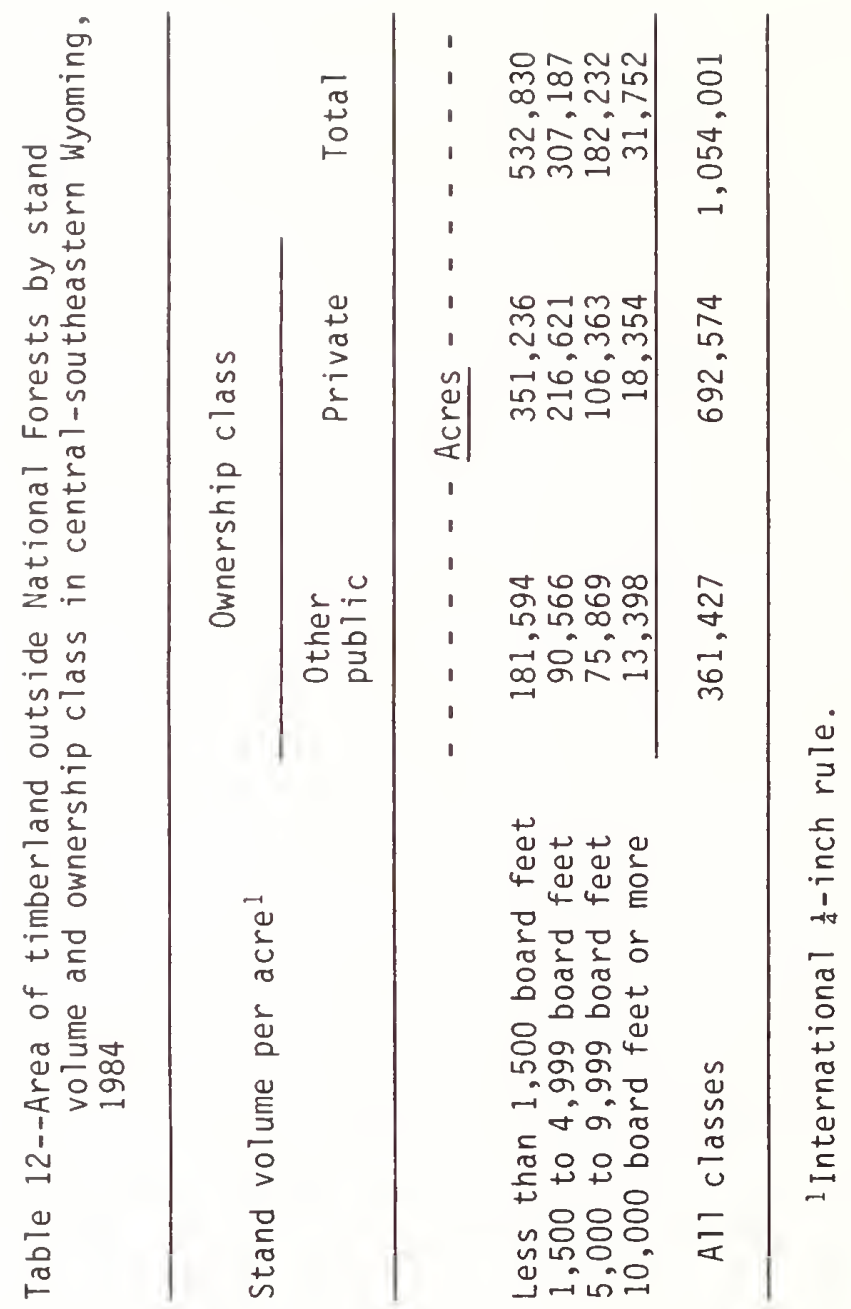




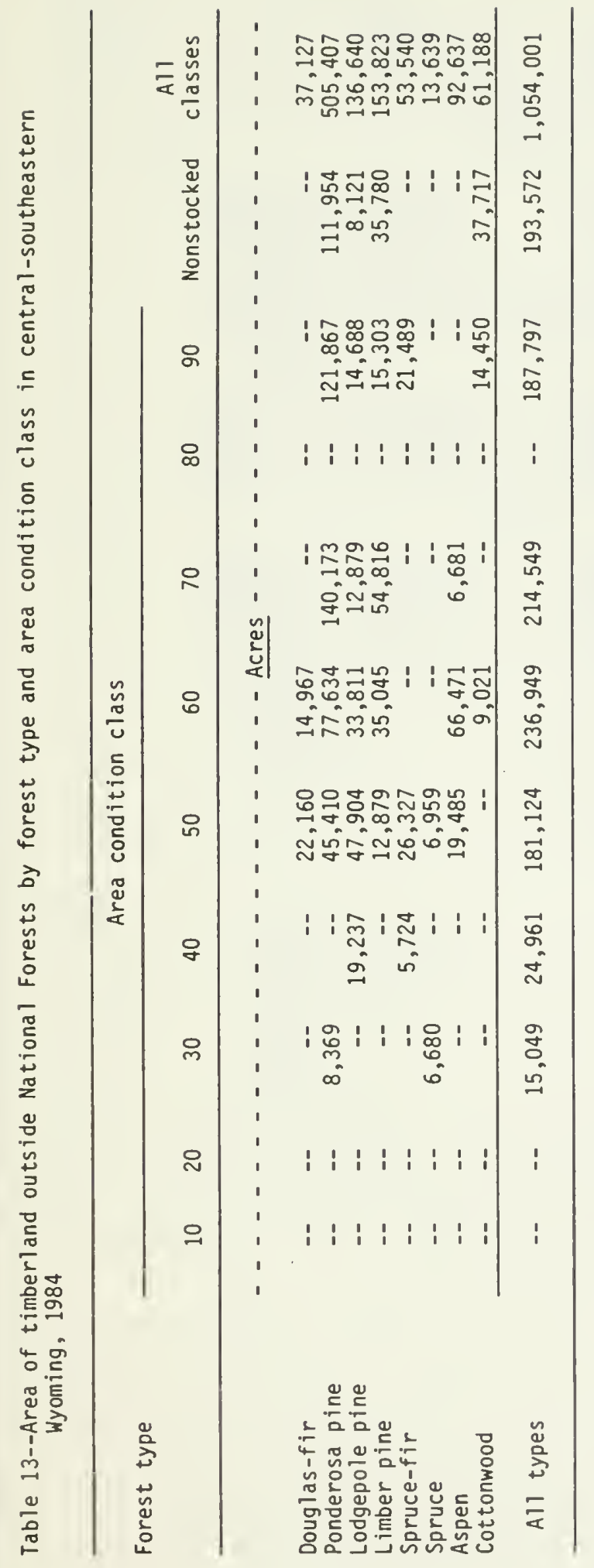

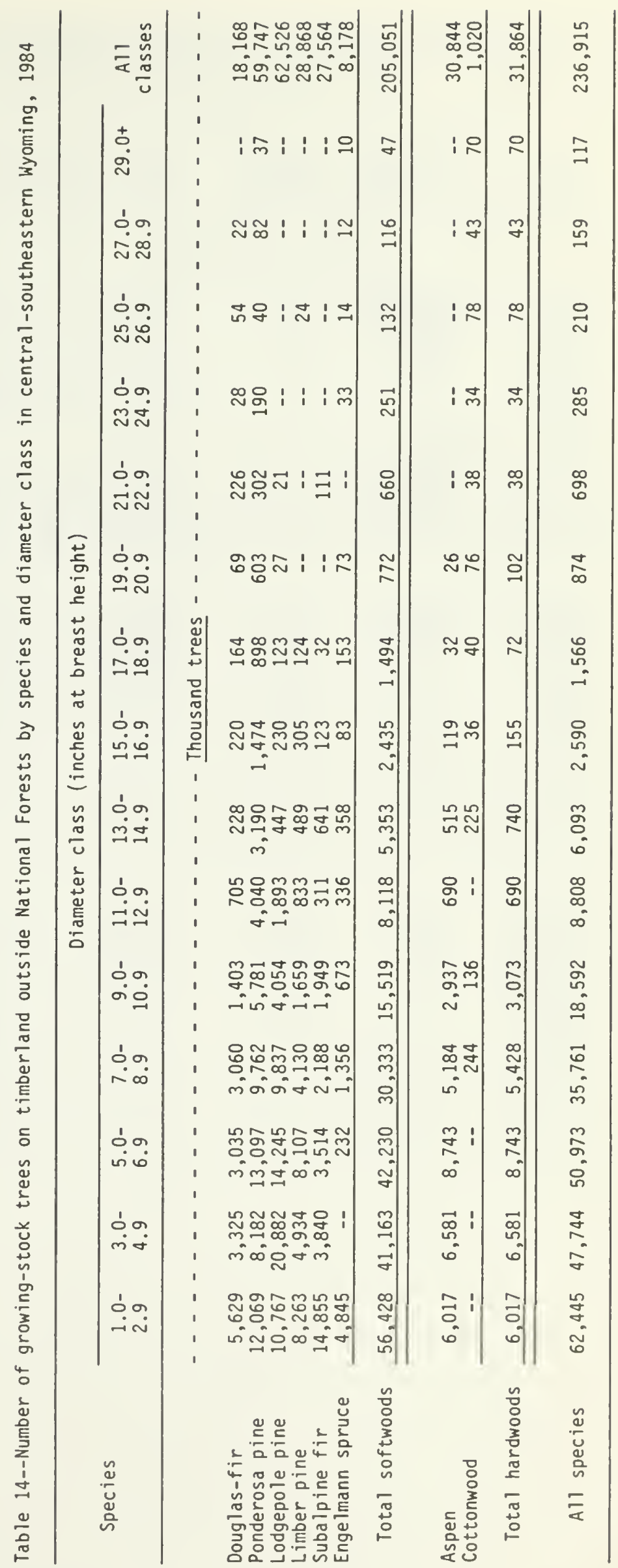


Table 15--Number of cull and salvable déad trees on timberland outside National Forests by ownership class, and softwoods and hardwoods in central-southeastern Wyoming, 1984

\begin{tabular}{|c|c|c|c|c|c|}
\hline \multirow{2}{*}{$\begin{array}{l}\text { Ownership class and } \\
\text { species group }\end{array}$} & \multicolumn{3}{|c|}{ Cull trees } & \multirow{2}{*}{$\begin{array}{l}\text { Salvable } \\
\text { dead trees }\end{array}$} & \multirow[b]{2}{*}{ Total } \\
\hline & Rough & Rotten & Total & & \\
\hline & --- & $-\cdots$ & Thousan & ees - - - & $-\cdots$ \\
\hline $\begin{array}{l}\text { 0ther public: } \\
\text { Sof twoods } \\
\text { Hardwoods }\end{array}$ & $\begin{array}{r}747 \\
-- \\
\end{array}$ & $\begin{array}{r}731 \\
-- \\
\end{array}$ & $\begin{array}{r}1,478 \\
-- \\
\end{array}$ & $\begin{array}{l}6,750 \\
1,092 \\
\end{array}$ & $\begin{array}{l}8,228 \\
1,092 \\
\end{array}$ \\
\hline Total & 747 & 731 & 1,478 & 7,842 & 9,320 \\
\hline $\begin{array}{l}\text { Private: } \\
\text { Softwoods } \\
\text { Hardwoods }\end{array}$ & $\begin{array}{r}344 \\
418 \\
\end{array}$ & $\begin{array}{r}43 \\
883 \\
\end{array}$ & $\begin{array}{r}387 \\
1,301 \\
\end{array}$ & $\begin{array}{l}4,705 \\
4,431 \\
\end{array}$ & $\begin{array}{r}5,092 \\
5,732 \\
\end{array}$ \\
\hline Total & 762 & 926 & 1,688 & 9,136 & 10,824 \\
\hline $\begin{array}{l}\text { Total: } \\
\text { Sof twoods } \\
\text { Hardwoods }\end{array}$ & $\begin{array}{r}1,091 \\
418 \\
\end{array}$ & $\begin{array}{l}774 \\
883 \\
\end{array}$ & $\begin{array}{l}1,865 \\
1,301 \\
\end{array}$ & $\begin{array}{r}11,455 \\
5,523 \\
\end{array}$ & $\begin{array}{r}13,320 \\
6,824 \\
\end{array}$ \\
\hline Total & 1,509 & 1,657 & 3,166 & 16,978 & 20,144 \\
\hline
\end{tabular}


Table 16--Net volume of growing stock on timberland outside National Forests by ownership class, forest type, and stand-size class in central-southeastern Wyoming, 1984

\begin{tabular}{lllll}
\hline \multirow{2}{*}{$\begin{array}{c}\text { Ownership } \\
\text { class }\end{array}$} & Forest type & Stand-size class & \\
\cline { 2 - 5 } & Sawtimber Poletimber & $\begin{array}{l}\text { Sapling/ } \\
\text { seedling }\end{array}$ & Nonstocked All & Plasses \\
\hline
\end{tabular}

Other public:

Douglas-fir
Ponderosa pine
Lodgepole pine
Limber pine
Spruce-fir
Spruce
Aspen
Cottonwood

Al1 types

Private:

Douglas-fir
Ponderosa pine
Lodgepole pine
Limber pine
Spruce-fir
Spruce
Aspen
Cottonwood

All types

Total:
Douglas-fir Ponderosa pine Lodgepole pine Limber pine Spruce-fir Spruce Aspen Cottonwood

All types

$$
\begin{aligned}
& 13,568 \\
& 83,386 \\
& 11,010 \\
& 18,313 \\
& 67,403 \\
& 29,801
\end{aligned}
$$

-- $\quad 23,873$

$--$
17,098
15,561
80,848
18,825
--

$-$

223,481

156,205

1,702

1,442

260

--

--

$-$

$--$

$\begin{array}{rr}-- & 32,108 \\ 2,623 & 101,570 \\ -- & 92,118 \\ 529 & 37,667 \\ -- & 67,403 \\ -- & 29,801 \\ -- & 23,873 \\ -- & -\end{array}$

223,481

18,471

200,483

57,756

74,603

31,285

3,967

25,264

19,352
11,806
71,739
2,558
27,182
36,534
36,534
7,749
3,626
4,608

576

576

--

--

16,559

149,819

431,181

149,819

32,039

283,869

17,098

27,367

152,587

68,766

92,916

98,688

33,768

25,264

19,352

21,383

27,182

60,407

1,442
7,749
3,886

4,608

576

--

$654,662 \quad 306,024$

18,261

--

7,379

\begin{tabular}{rr}
-- & 50,579 \\
8,448 & 327,433 \\
697 & 225,936 \\
529 & 114,828 \\
-- & 130,478 \\
-- & 33,768 \\
-- & 86,247 \\
7,379 & 26,731 \\
\hline
\end{tabular}

17,053

996,000 
Table 17--Net volume of sawtimber (International $\frac{1}{4}$-inch rule) on timberland outside National Forests by ownership class, forest type, and stand-size class in central-southeastern Wyoming, 1984

\begin{tabular}{|c|c|c|c|c|c|c|}
\hline \multirow[b]{2}{*}{$\begin{array}{l}\text { Ownership } \\
\text { class }\end{array}$} & \multirow{2}{*}{ Forest type } & \multicolumn{4}{|c|}{ Stand-size class } & \\
\hline & & Sawtimber & Poletimber & $\begin{array}{l}\text { Sapling/ } \\
\text { seedling }\end{array}$ & Nons tocked & $\begin{array}{c}\text { Al1 } \\
\text { classes }\end{array}$ \\
\hline
\end{tabular}

Other public:

Douglas-fir

Ponderosa pine

Lodgepole pine

Limber pine

Spruce-fir

Spruce

Aspen

Cottonwood

Al1 types

Private:

Douglas-fir

Ponderosa pine

Lodgepole pine

Limber pine

Spruce-fir

Spruce

Aspen

Cottonwood

All types

Total:

Douglas-fir

Ponderosa pine

Lodgepole pine

Limber pine

Spruce-fir

Spruce

Aspen

Cottonwood

Al1 types
- - Thousand board feet, International d-inch rule - - -

$\begin{array}{rrrrr}42,089 & 29,483 & 6,291 & -- & 77,863 \\ 301,152 & 23,759 & -- & 11,437 & 336,348 \\ 36,446 & 133,568 & -- & -- & 170,014 \\ 53,967 & 22,570 & -- & 1,569 & 78,106 \\ 260,614 & -- & -- & -- & 260,614 \\ 97,279 & -- & -- & -- & 97,279 \\ -- & 38,221 & -- & -- & 38,221 \\ -- & -- & -- & -- & --\end{array}$

$\begin{array}{lllll}791,547 & 247,601 & 6,291 & 13,006 & 1,058,445\end{array}$

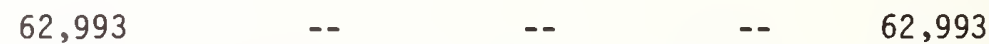

$802,444 \quad 20,142 \quad 13,146 \quad 24,689 \quad 860,421$

$\begin{array}{lllll}193,746 & 86,700 & 7,476 & 2,135 & 290,057\end{array}$

$\begin{array}{lllll}348,080 & 3,359 & -- & - & 351,439\end{array}$

$\begin{array}{lllll}106,463 & 44,711 & 4,351 & - & 155,525\end{array}$

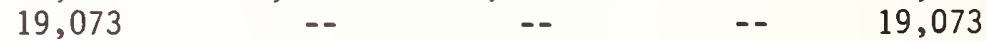

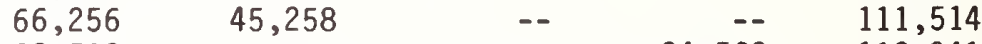

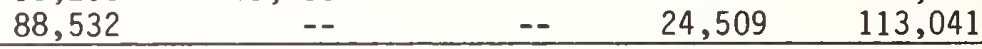

$\begin{array}{lllll}1,687,587 & 200,170 & 24,973 & 51,333 & 1,964,063\end{array}$

\begin{tabular}{rrrrr}
105,082 & 29,483 & 6,291 & -- & 140,856 \\
$1,103,596$ & 43,901 & 13,146 & 36,126 & $1,196,769$ \\
230,192 & 220,268 & 7,476 & 2,135 & 460,071 \\
402,047 & 25,929 & -- & 1,569 & 429,545 \\
367,077 & 44,711 & 4,351 & -- & 416,139 \\
116,352 & -- & -- & -- & 116,352 \\
66,256 & 83,479 & -- & -- & 149,735 \\
88,532 & -- & -- & 24,509 & 113,041 \\
\hline $2,479,134$ & 447,771 & 31,264 & 64,339 & $3,022,508$
\end{tabular}


Table 18--Net volume of sawtimber (Scribner rule) on timberland outside National Forests by ownership class, forest type, and stand-size class in central-southeastern Wyoming, 1984

Ownership
class $\quad$ Forest type

Stand-size class

$\begin{array}{llll}\text { Sawtimber Poletimber } & \begin{array}{l}\text { Sapling/ } \\ \text { seedling }\end{array} & \text { Nonstocked } \\ \text { classes }\end{array}$

Other public:

Douglas-fir
Ponderosa pine
Lodgepole pine
Limber pine
Spruce-fir
Spruce
Aspen
Cottonwood

All types

Private:
- - - - Thousand board feet, Scribner rule - - - -

\begin{tabular}{rrrrr}
35,674 & 25,507 & 4,900 & -- & 66,081 \\
256,710 & 19,096 & -- & 9,270 & 285,076 \\
31,186 & 114,989 & -- & -- & 146,175 \\
45,577 & 19,663 & -- & 1,380 & 66,620 \\
222,736 & -- & -- & -- & 222,736 \\
81,567 & -- & -- & -- & 81,567 \\
-- & 32,490 & -- & -- & 32,490 \\
-- & -- & -- & -- & -- \\
\hline
\end{tabular}

\begin{tabular}{lllll}
673,450 & 211,745 & 4,900 & 10,650 & 900,745 \\
\hline
\end{tabular}

Total:

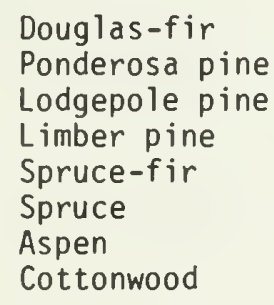

A11 types

\begin{tabular}{rrrrr}
52,660 & -- & -- & -- & 52,660 \\
684,931 & 15,509 & 10,877 & 20,740 & 732,057 \\
164,888 & 74,533 & 6,401 & 1,899 & 247,721 \\
300,079 & 2,862 & -- & -- & 302,941 \\
89,446 & 38,585 & 3,720 & -- & 131,751 \\
15,620 & -- & -- & -- & 15,620 \\
56,304 & 38,723 & -- & -- & 95,027 \\
77,538 & -- & -- & 21,293 & 98,831 \\
\hline $1,441,466$ & 170,212 & 20,998 & 43,932 & $1,676,608$ \\
\hline
\end{tabular}

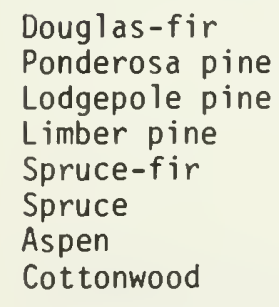

All types

\begin{tabular}{rrrrr}
88,334 & 25,507 & 4,900 & -- & 118,741 \\
941,641 & 34,605 & 10,877 & 30,010 & $1,017,133$ \\
196,074 & 189,522 & 6,401 & 1,899 & 393,896 \\
345,656 & 22,525 & -- & 1,380 & 369,561 \\
312,182 & 38,585 & 3,720 & -- & 354,487 \\
97,187 & -- & -- & -- & 97,187 \\
56,304 & 71,213 & -- & -- & 127,517 \\
77,538 & -- & -- & 21,293 & 98,831 \\
\hline $2,114,916$ & 381,957 & 25,898 & 54,582 & $2,577,353$ \\
\hline
\end{tabular}


Table 19--Net volume of growing stock on timberland outside National Forests by species and ownership class in central-southeastern Wyoming, 1984

\begin{tabular}{|c|c|c|c|}
\hline \multirow{2}{*}{ Species } & \multicolumn{2}{|c|}{ Ownership class } & \multirow[b]{2}{*}{ Total } \\
\hline & $\begin{array}{l}\text { Other } \\
\text { public }\end{array}$ & Private & \\
\hline & $-\cdot-\cdot$ & and cubic & $t \cdots-\cdots$ \\
\hline $\begin{array}{l}\text { Douglas-fir } \\
\text { Ponderosa pine } \\
\text { Lodgepole pine } \\
\text { Limber pine } \\
\text { Subalpine fir } \\
\text { Engelmann spruce }\end{array}$ & $\begin{array}{r}41,637 \\
95,994 \\
101,527 \\
30,836 \\
39,667 \\
42,557 \\
\end{array}$ & $\begin{array}{r}48,180 \\
230,739 \\
138,505 \\
49,970 \\
34,705 \\
13,503 \\
\end{array}$ & $\begin{array}{r}89,817 \\
326,733 \\
240,032 \\
80,806 \\
74,372 \\
56,060 \\
\end{array}$ \\
\hline Total softwoods & 352,218 & 515,602 & 867,820 \\
\hline $\begin{array}{l}\text { Aspen } \\
\text { Cottonwood }\end{array}$ & $\begin{array}{r}32,322 \\
-- \\
\end{array}$ & $\begin{array}{l}69,127 \\
26,731 \\
\end{array}$ & $\begin{array}{r}101,449 \\
26,731 \\
\end{array}$ \\
\hline Total hardwoods & 32,322 & 95,858 & 128,180 \\
\hline All species & 384,540 & 611,460 & 996,000 \\
\hline
\end{tabular}

Table 20--Net volume of sawtimber (International d-inch rule) on timberland outside National Forests by species and ownership class in central-southeastern Wyoming, 1984

\begin{tabular}{|c|c|c|c|}
\hline \multirow{2}{*}{ Species } & \multicolumn{2}{|c|}{ Ownership class } & \multirow[b]{2}{*}{ Total } \\
\hline & $\begin{array}{l}\text { Other } \\
\text { public }\end{array}$ & Private & \\
\hline & - Thousand b & eet, Intern & 1 t-inch rule. \\
\hline $\begin{array}{l}\text { Douglas-fir } \\
\text { Ponderosa pine } \\
\text { Lodgepole pine } \\
\text { Limber pine } \\
\text { Subalpine fir } \\
\text { Engelmann spruce }\end{array}$ & $\begin{array}{r}102,331 \\
341,264 \\
218,434 \\
44,316 \\
138,151 \\
162,852 \\
\end{array}$ & $\begin{array}{r}232,989 \\
888,304 \\
318,124 \\
181,663 \\
100,737 \\
54,139 \\
\end{array}$ & $\begin{array}{r}335,320 \\
1,229,568 \\
536,558 \\
225,979 \\
238,888 \\
216,991 \\
\end{array}$ \\
\hline Total softwoods & $1,007,348$ & $1,775,956$ & $2,783,304$ \\
\hline $\begin{array}{l}\text { Aspen } \\
\text { Cottonwood }\end{array}$ & $\begin{array}{r}51,097 \\
-- \\
\end{array}$ & $\begin{array}{r}75,066 \\
113,041 \\
\end{array}$ & $\begin{array}{l}126,163 \\
113,041 \\
\end{array}$ \\
\hline Total hardwoods & 51,097 & 188,107 & 239,204 \\
\hline All species & $1,058,445$ & $1,964,063$ & $3,022,508$ \\
\hline
\end{tabular}


Table 21--Net volume of sawtimber (Scribner rule) on timberland outside National Forests by species and ownership class in central-southeastern Wyoming, 1984

\begin{tabular}{|c|c|c|c|}
\hline \multirow{2}{*}{ Species } & \multicolumn{2}{|c|}{ Ownership class } & \multirow[b]{2}{*}{ Total } \\
\hline & $\begin{array}{l}\text { Other } \\
\text { public }\end{array}$ & Private & \\
\hline & \multicolumn{3}{|c|}{ - Thousand board feet, Scribner rule - } \\
\hline $\begin{array}{l}\text { Douglas-fir } \\
\text { Ponderosa pine } \\
\text { Lodgepole pine } \\
\text { Limber pine } \\
\text { Subalpine fir } \\
\text { Engelmann spruce }\end{array}$ & $\begin{array}{r}87,533 \\
289,372 \\
186,567 \\
37,203 \\
117,742 \\
138,893 \\
\end{array}$ & $\begin{array}{r}201,411 \\
756,096 \\
271,694 \\
154,204 \\
85,594 \\
44,954 \\
\end{array}$ & $\begin{array}{r}288,944 \\
1,045,468 \\
458,261 \\
191,407 \\
203,336 \\
183,847 \\
\end{array}$ \\
\hline Total softwoods & 857,310 & $1,513,953$ & $2,371,263$ \\
\hline $\begin{array}{l}\text { Aspen } \\
\text { Cottonwood }\end{array}$ & $\begin{array}{r}43,435 \\
-- \\
\end{array}$ & $\begin{array}{l}63,825 \\
98,830 \\
\end{array}$ & $\begin{array}{r}107,260 \\
98,830 \\
\end{array}$ \\
\hline Total hardwoods & 43,435 & 162,655 & 206,090 \\
\hline All species & 900,745 & $1,676,608$ & $2,577,353$ \\
\hline
\end{tabular}




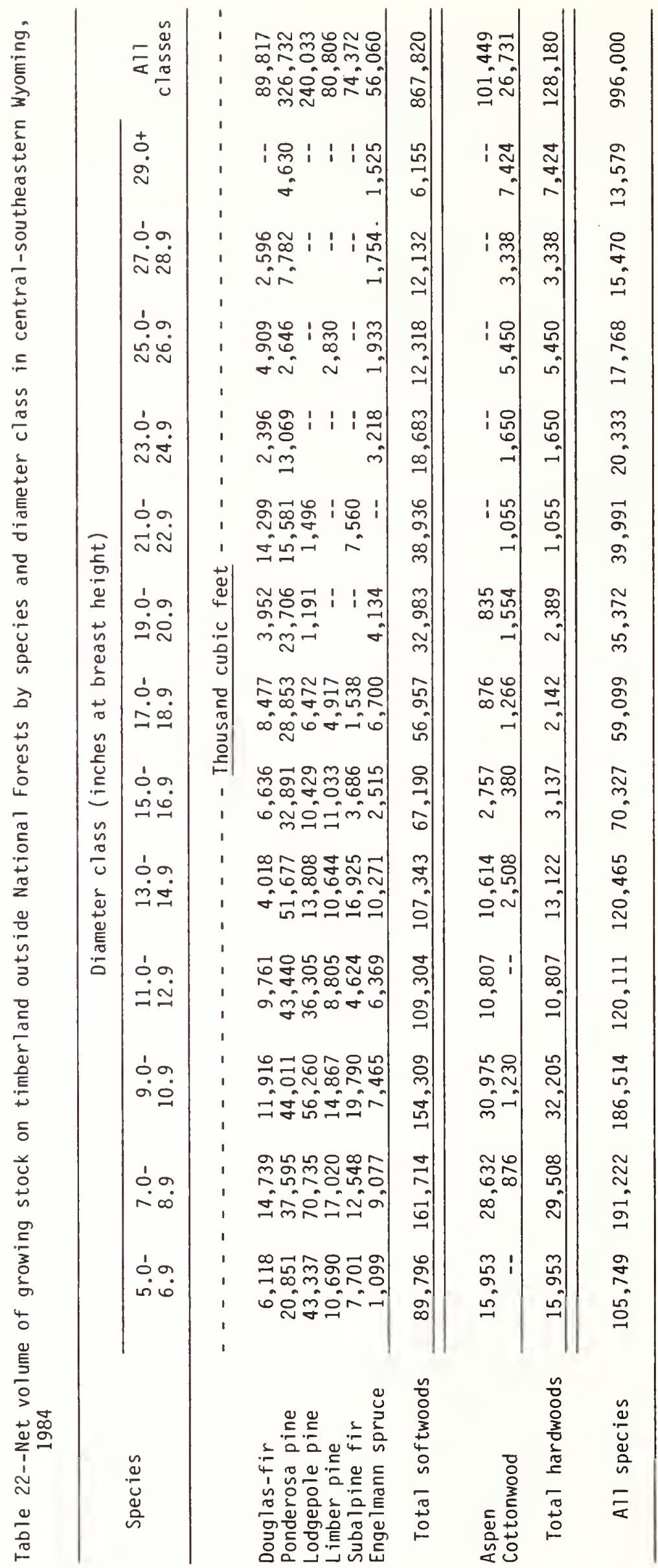




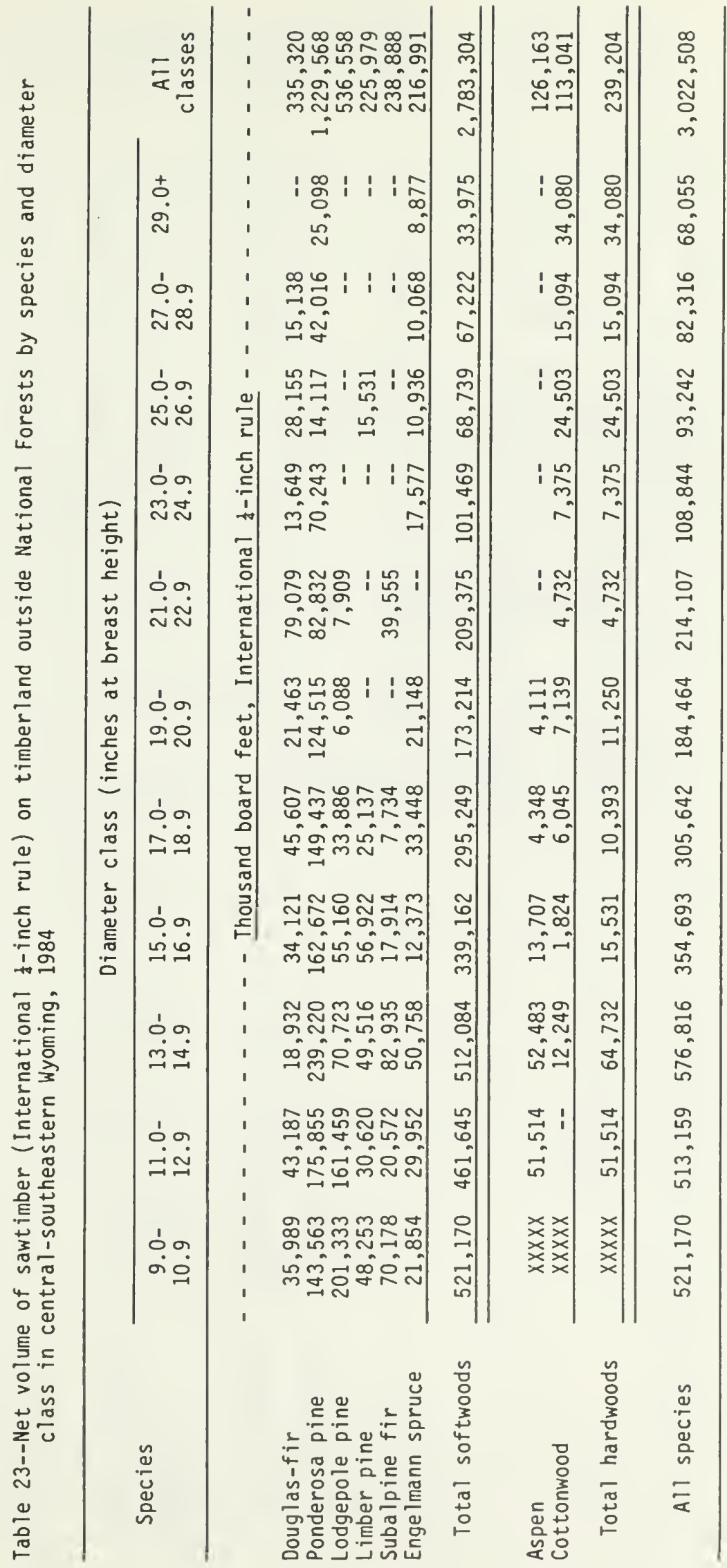




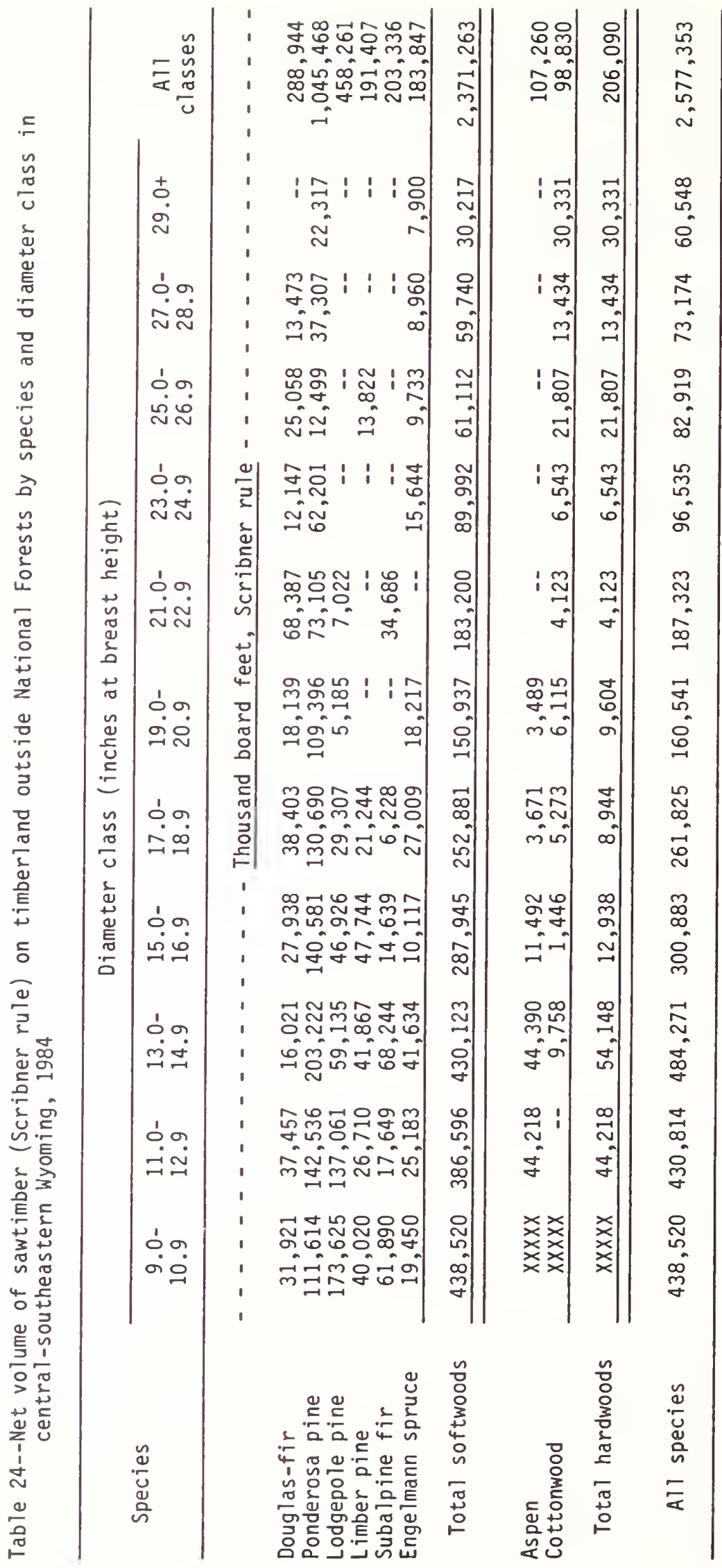




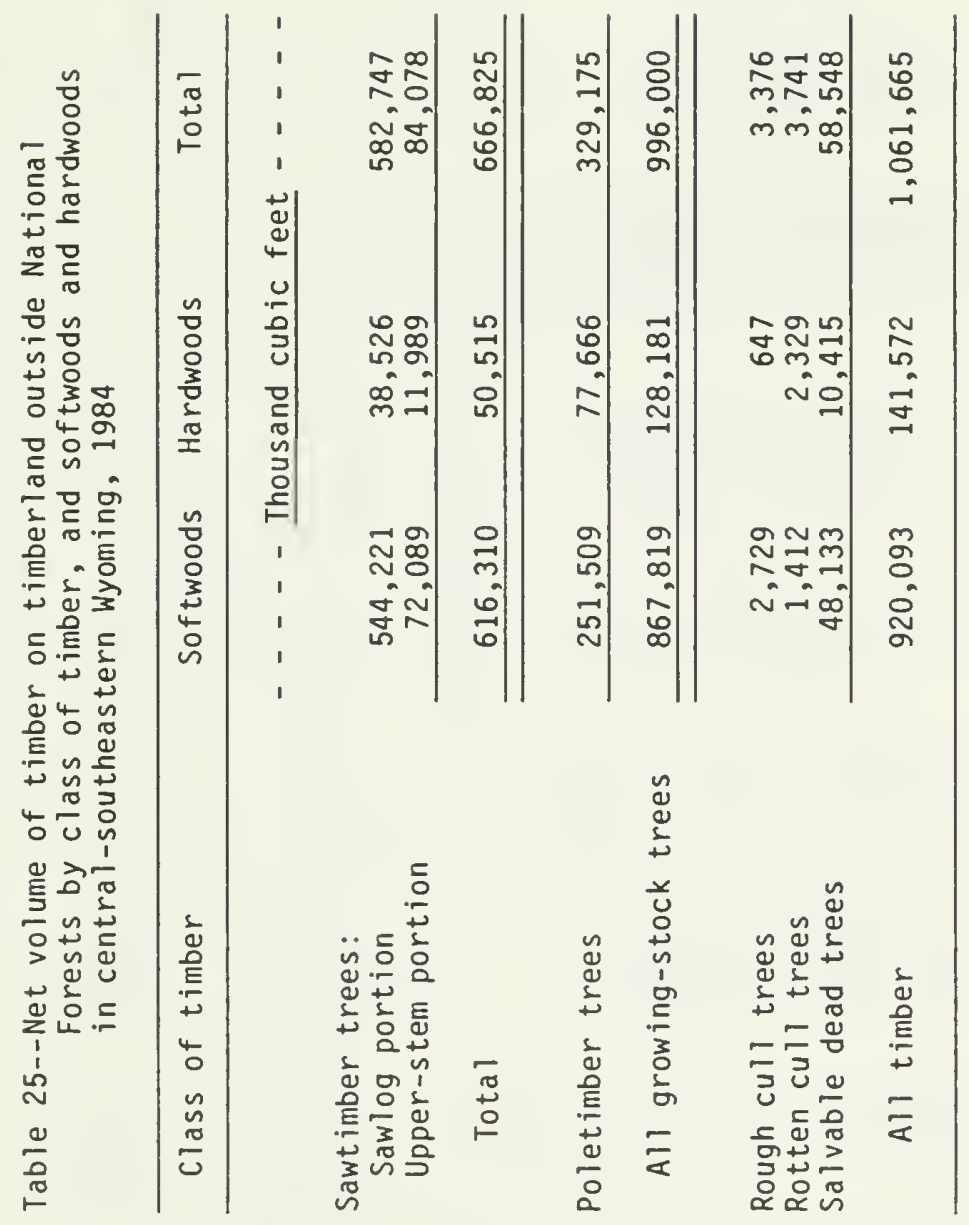



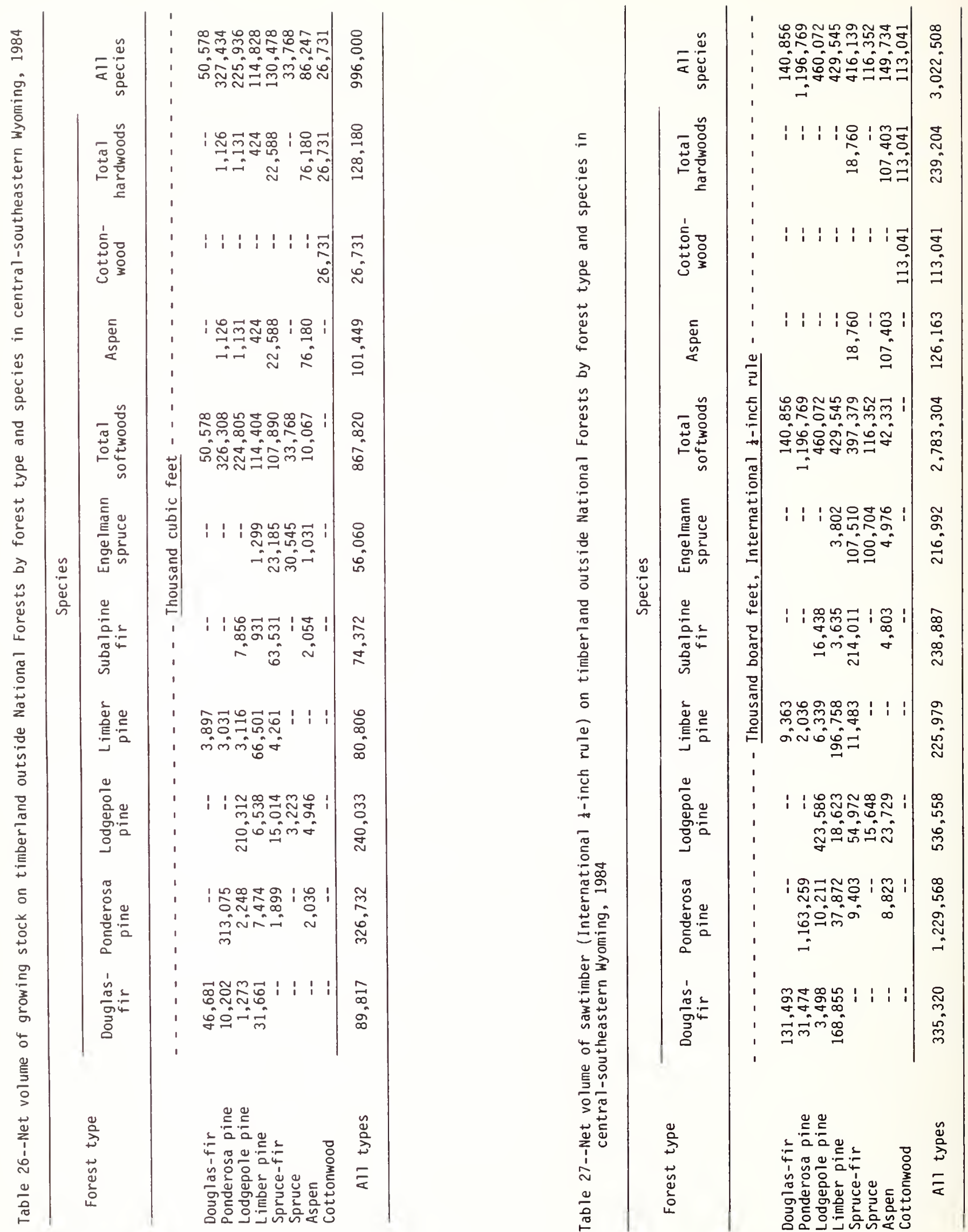


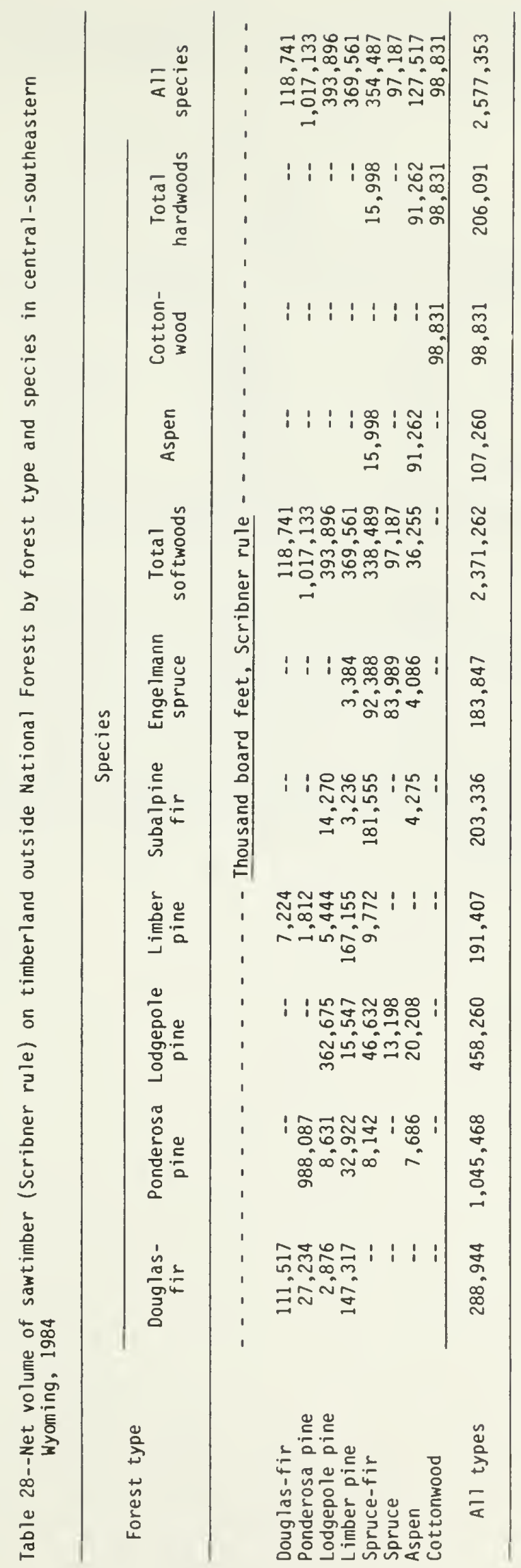


Table 29--Net annual growth of growing stock on timberland outside National Forests by species and ownership class in central-southeastern Wyoming, 1983

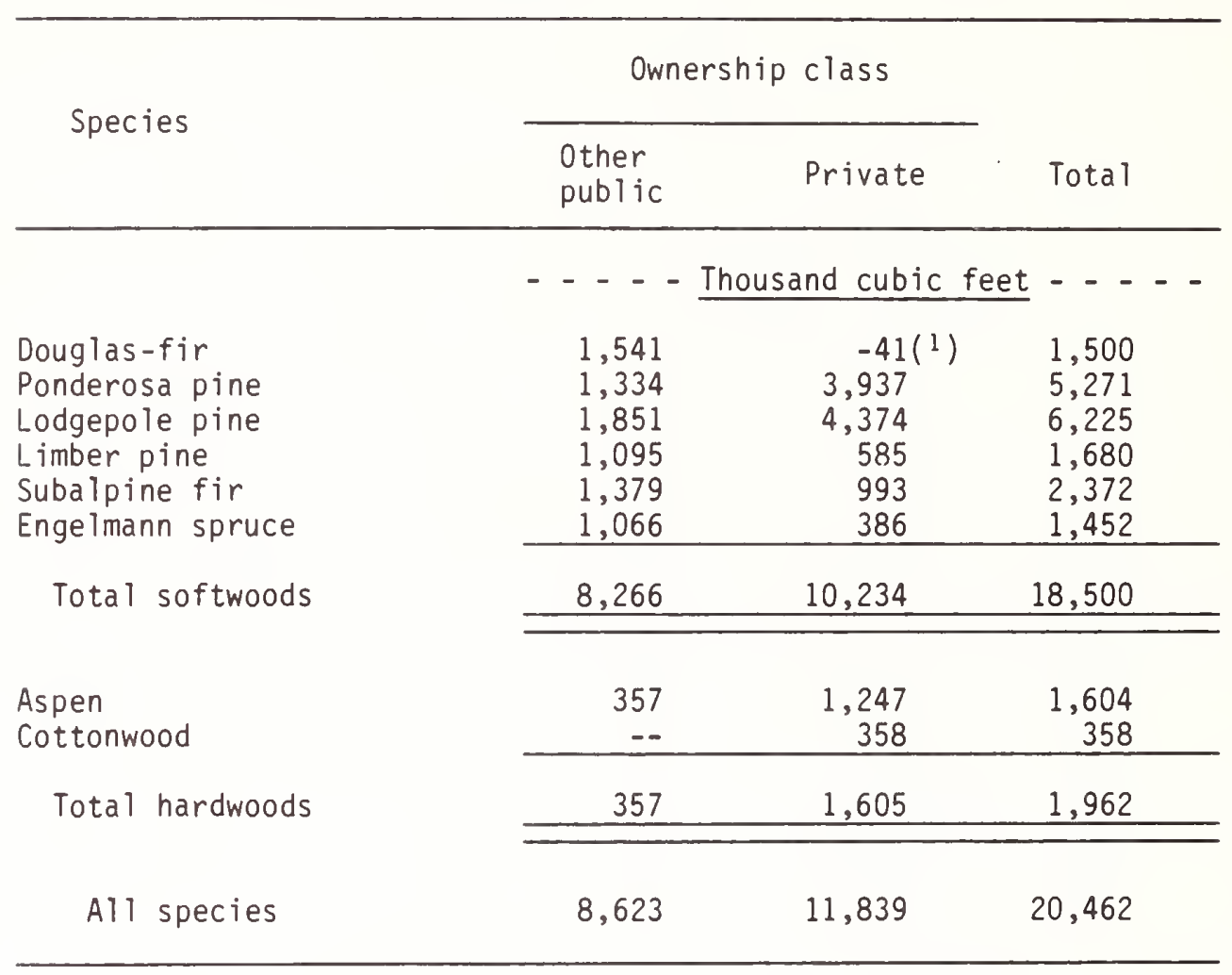

${ }^{1}$ Net annual growth is negative when annual mortality exceeds gross annual growth. 
Table 30--Net annual growth of sawtimber (International $\frac{1}{4}$-inch rule) on timberland outside National Forests by species and ownership class in central-southeastern Wyoming, 1983

\begin{tabular}{|c|c|c|c|}
\hline \multirow{2}{*}{ Species } & \multicolumn{2}{|c|}{ Ownership class } & \multirow[b]{2}{*}{ Tota 1} \\
\hline & $\begin{array}{l}\text { Other } \\
\text { public }\end{array}$ & Private & \\
\hline & - Thousand & et, Internat & t-inch rule. \\
\hline $\begin{array}{l}\text { Douglas-fir } \\
\text { Ponderosa pine } \\
\text { Lodgepole pine } \\
\text { Limber pine } \\
\text { Subalpine fir } \\
\text { Engelmann spruce }\end{array}$ & $\begin{array}{r}9,047 \\
5,676 \\
7,706 \\
2,290 \\
9,911 \\
3,656 \\
\end{array}$ & $\begin{array}{l}-934\left({ }^{1}\right) \\
18,323 \\
10,578 \\
1,820 \\
2,315 \\
1,657 \\
\end{array}$ & $\begin{array}{r}8,113 \\
23,999 \\
18,284 \\
4,110 \\
12,226 \\
5,313 \\
\end{array}$ \\
\hline Total softwoods & 38,286 & 33,759 & 72,045 \\
\hline $\begin{array}{l}\text { Aspen } \\
\text { Cottonwood }\end{array}$ & $\begin{array}{r}181 \\
-- \\
\end{array}$ & $\begin{array}{r}-22 \\
2,839 \\
\end{array}$ & $\begin{array}{r}159 \\
2,839 \\
\end{array}$ \\
\hline Total hardwoods & 181 & 2,817 & 2,998 \\
\hline All species & 38,467 & 36,576 & 75,043 \\
\hline
\end{tabular}

${ }^{1}$ Net annual growth is negative when annual mortality exceeds gross annual growth. 


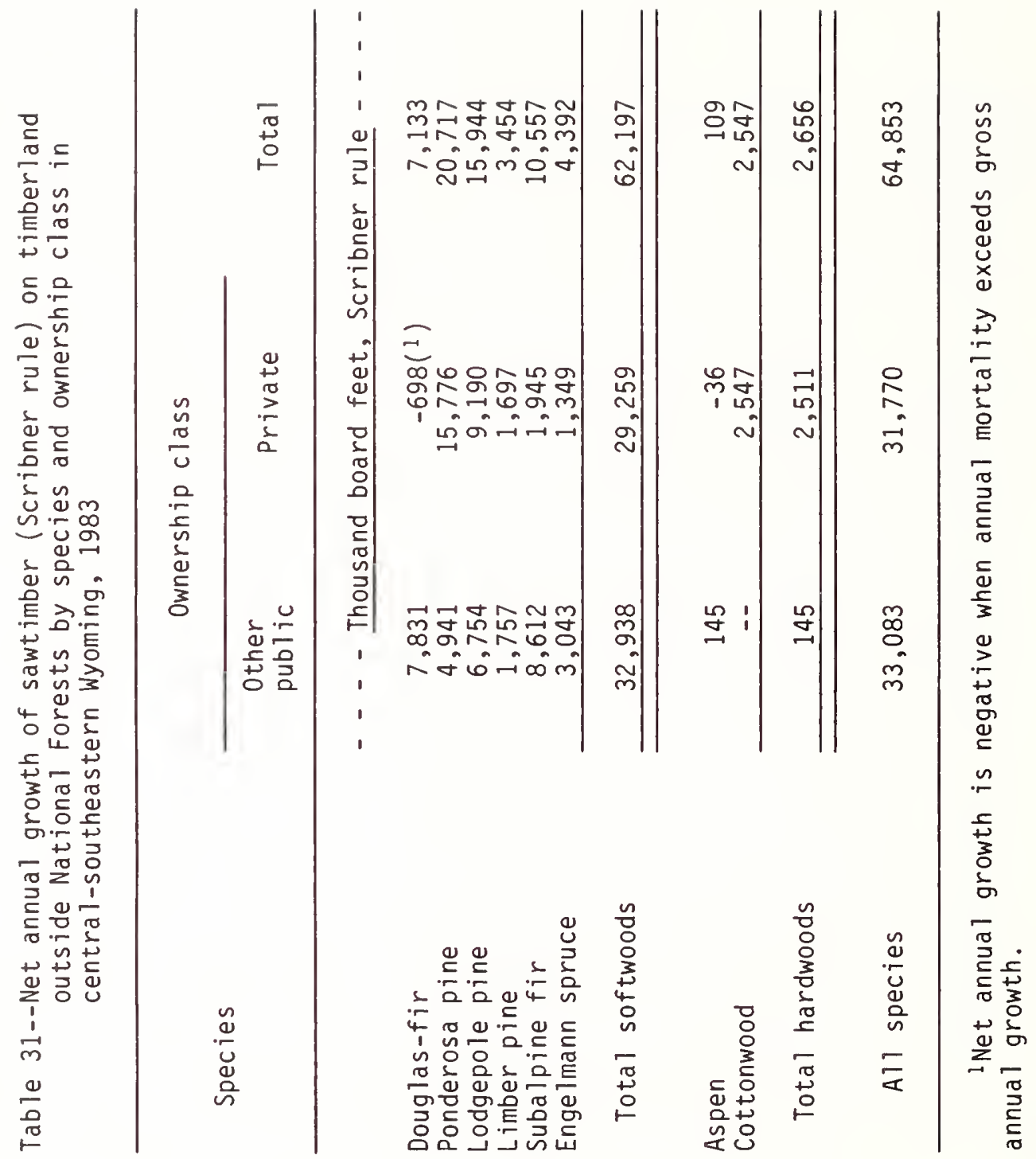




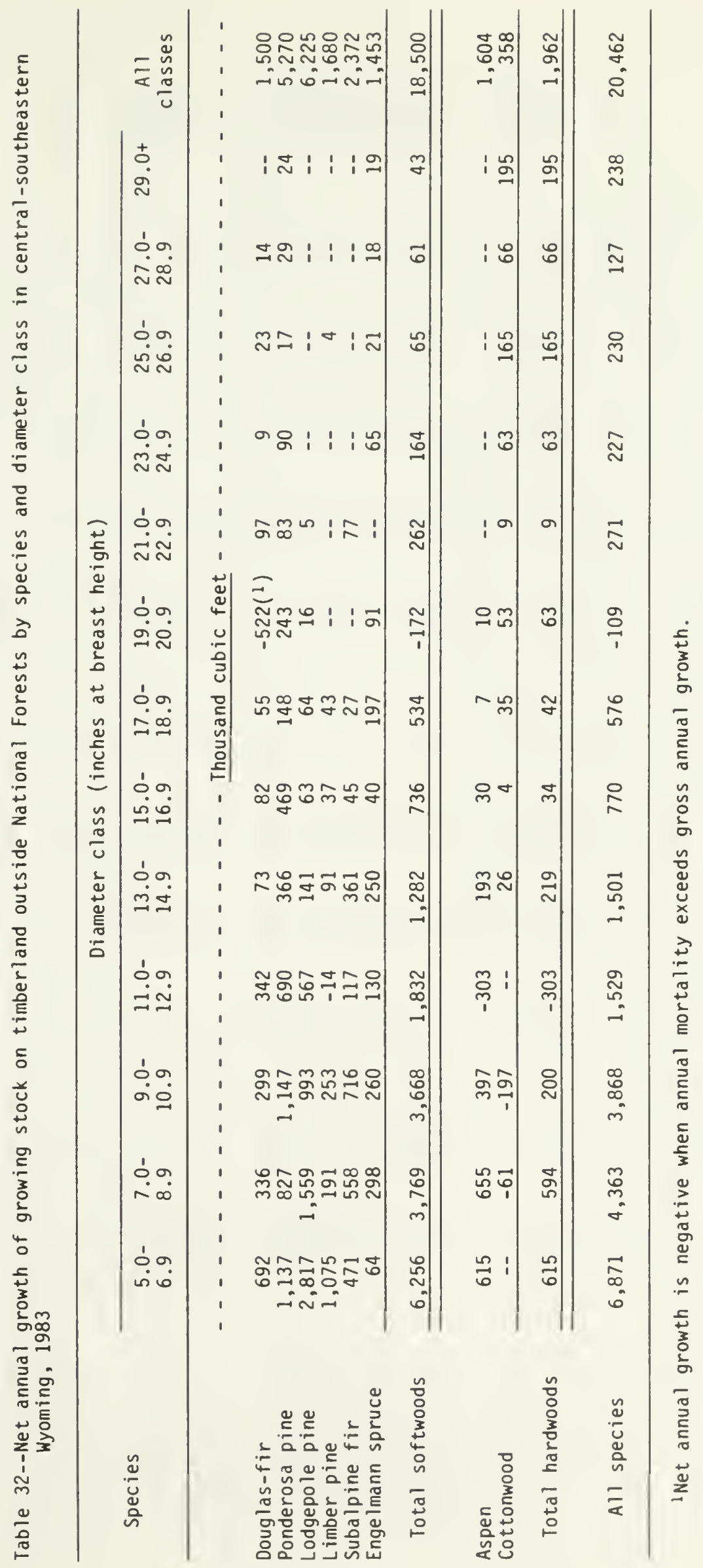




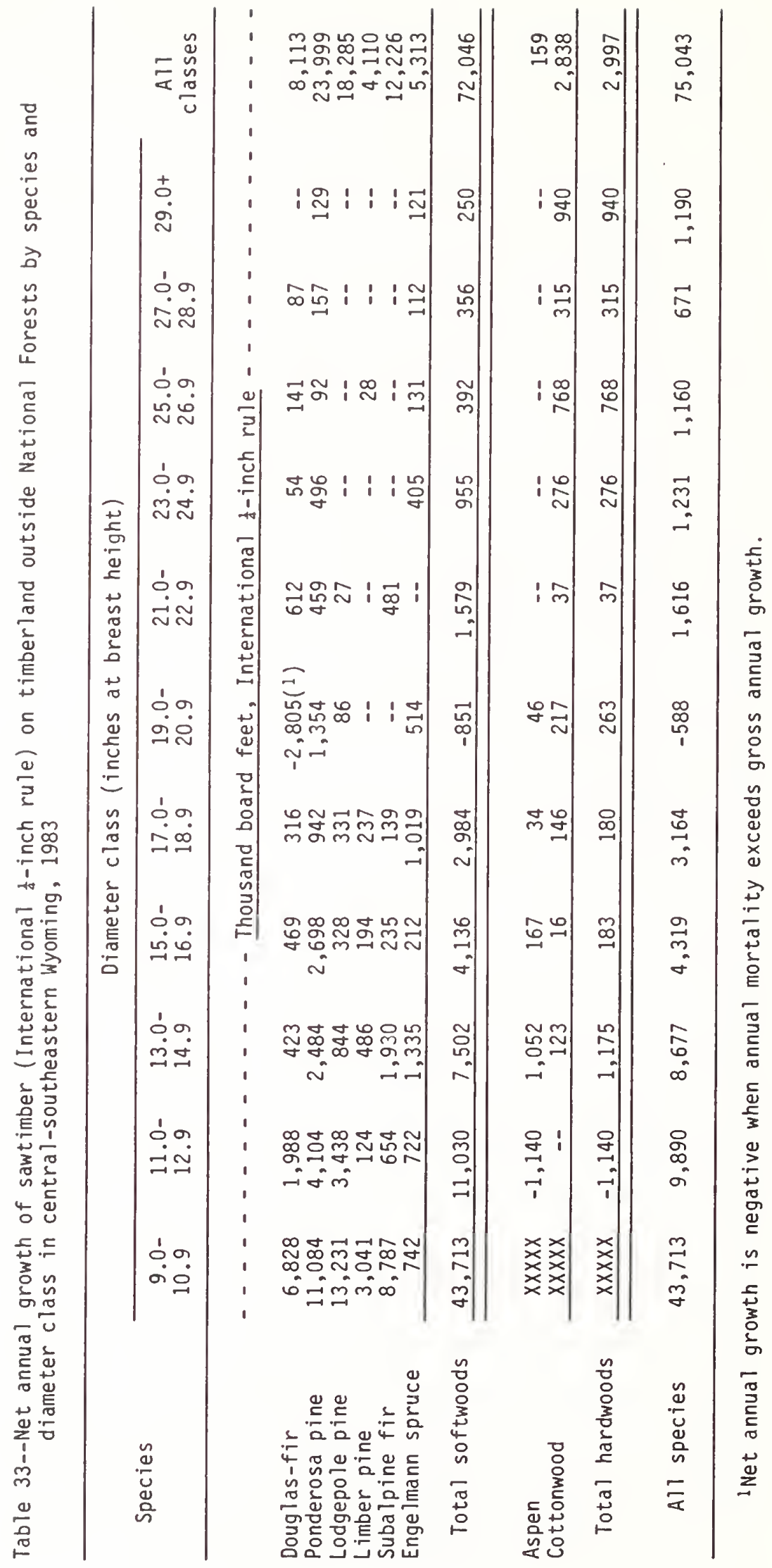




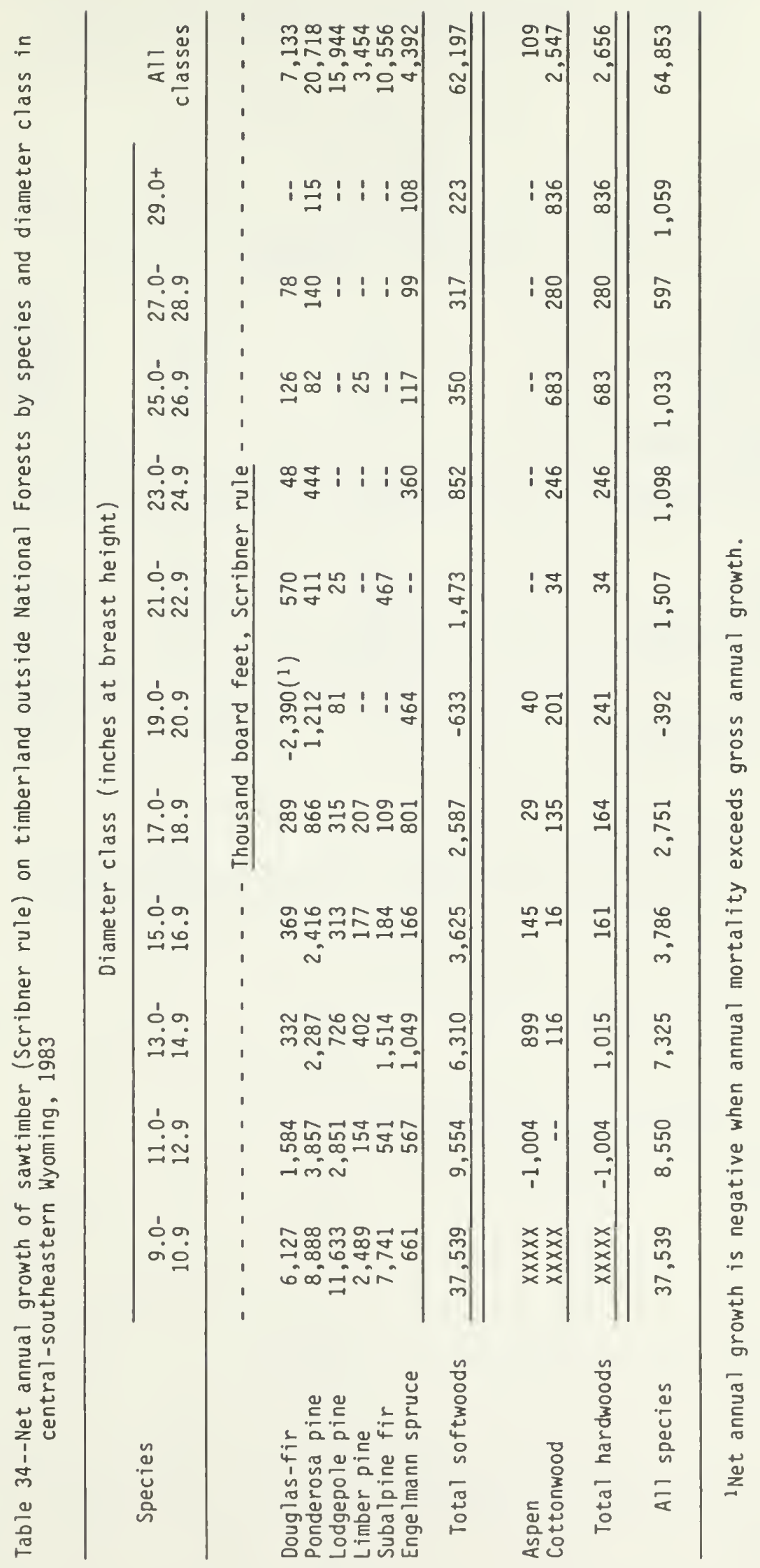


Table 35--Annual mortality of growing stock on timberland outside National Forests by species and ownership class in central-southeastern Wyoming, 1983

\begin{tabular}{|c|c|c|c|}
\hline \multirow{2}{*}{ Species } & \multicolumn{2}{|c|}{ Ownership class } & \multirow[b]{2}{*}{ Total } \\
\hline & $\begin{array}{l}\text { Other } \\
\text { public }\end{array}$ & Private & \\
\hline & $\cdots$ & and cubic & $-=$ \\
\hline $\begin{array}{l}\text { Douglas-fir } \\
\text { Ponderosa pine } \\
\text { Lodgepole pine } \\
\text { Limber pine } \\
\text { Subalpine fir } \\
\text { Engelmann spruce }\end{array}$ & $\begin{array}{r}-- \\
689 \\
-- \\
493 \\
-- \\
--\end{array}$ & $\begin{array}{r}564 \\
254 \\
149 \\
156 \\
76 \\
--\end{array}$ & $\begin{array}{r}564 \\
943 \\
149 \\
649 \\
76 \\
--\end{array}$ \\
\hline Total softwoods & 1,182 & 1,199 & 2,381 \\
\hline $\begin{array}{l}\text { Aspen } \\
\text { Cottonwood }\end{array}$ & $\begin{array}{r}528 \\
-- \\
\end{array}$ & $\begin{array}{l}848 \\
353 \\
\end{array}$ & $\begin{array}{r}1,376 \\
353 \\
\end{array}$ \\
\hline Total hardwoods & 528 & 1,201 & 1,729 \\
\hline All species & 1,710 & 2,400 & 4,110 \\
\hline
\end{tabular}


Table 36--Annual mortality of sawtimber (International $\frac{1}{4}$-inch rule) on timberland outside National Forests by species and ownership class in central-southeastern Wyoming, 1983

\begin{tabular}{|c|c|c|c|}
\hline \multirow{2}{*}{ Species } & \multicolumn{2}{|c|}{ Ownership class } & \multirow[b]{2}{*}{ Total } \\
\hline & $\begin{array}{l}\text { Other } \\
\text { public }\end{array}$ & Private & \\
\hline & - Thousand b & $t$, Intern & -inch rule - \\
\hline $\begin{array}{l}\text { Douglas-fir } \\
\text { Ponderosa pine } \\
\text { Lodgepole pine } \\
\text { Limber pine } \\
\text { Subalpine fir } \\
\text { Engelmann spruce }\end{array}$ & $\begin{array}{r}-- \\
2,011 \\
-- \\
812 \\
-- \\
--\end{array}$ & $\begin{array}{r}3,059 \\
1,033 \\
-- \\
-- \\
-- \\
--\end{array}$ & $\begin{array}{r}3,059 \\
3,044 \\
-- \\
812 \\
-- \\
--\end{array}$ \\
\hline Total softwoods & 2,823 & 4,092 & 6,915 \\
\hline $\begin{array}{l}\text { Aspen } \\
\text { Cottonwood }\end{array}$ & $\begin{array}{r}925 \\
-. \\
\end{array}$ & $\begin{array}{r}1,592 \\
-- \\
\end{array}$ & $\begin{array}{r}2,517 \\
-- \\
\end{array}$ \\
\hline Total hardwoods & 925 & 1,592 & 2,517 \\
\hline All species & 3,748 & 5,684 & 9,432 \\
\hline
\end{tabular}

Table 37--Annual mortality of sawtimber (Scribner rule) on timberland outside National Forests by species and ownership class in central-southeastern Wyoming, 1983

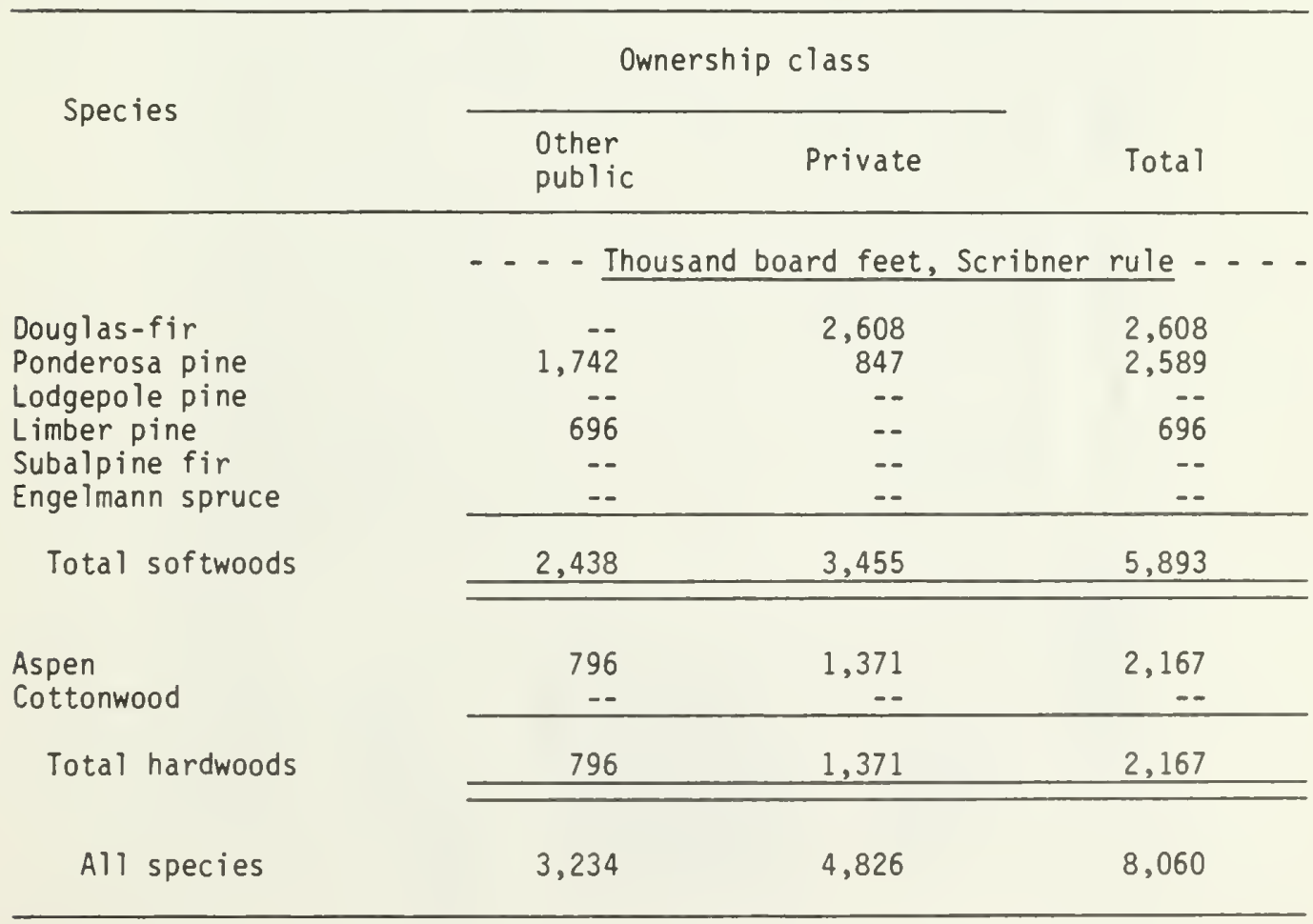




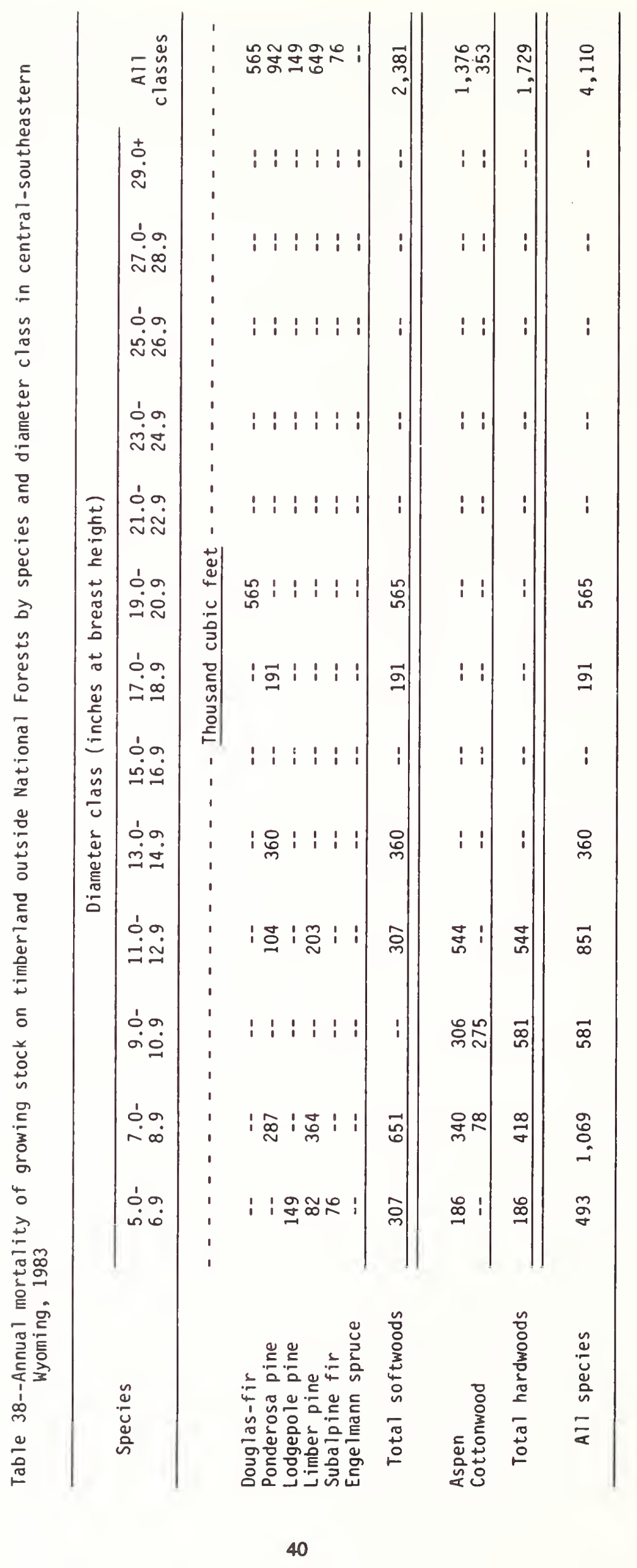




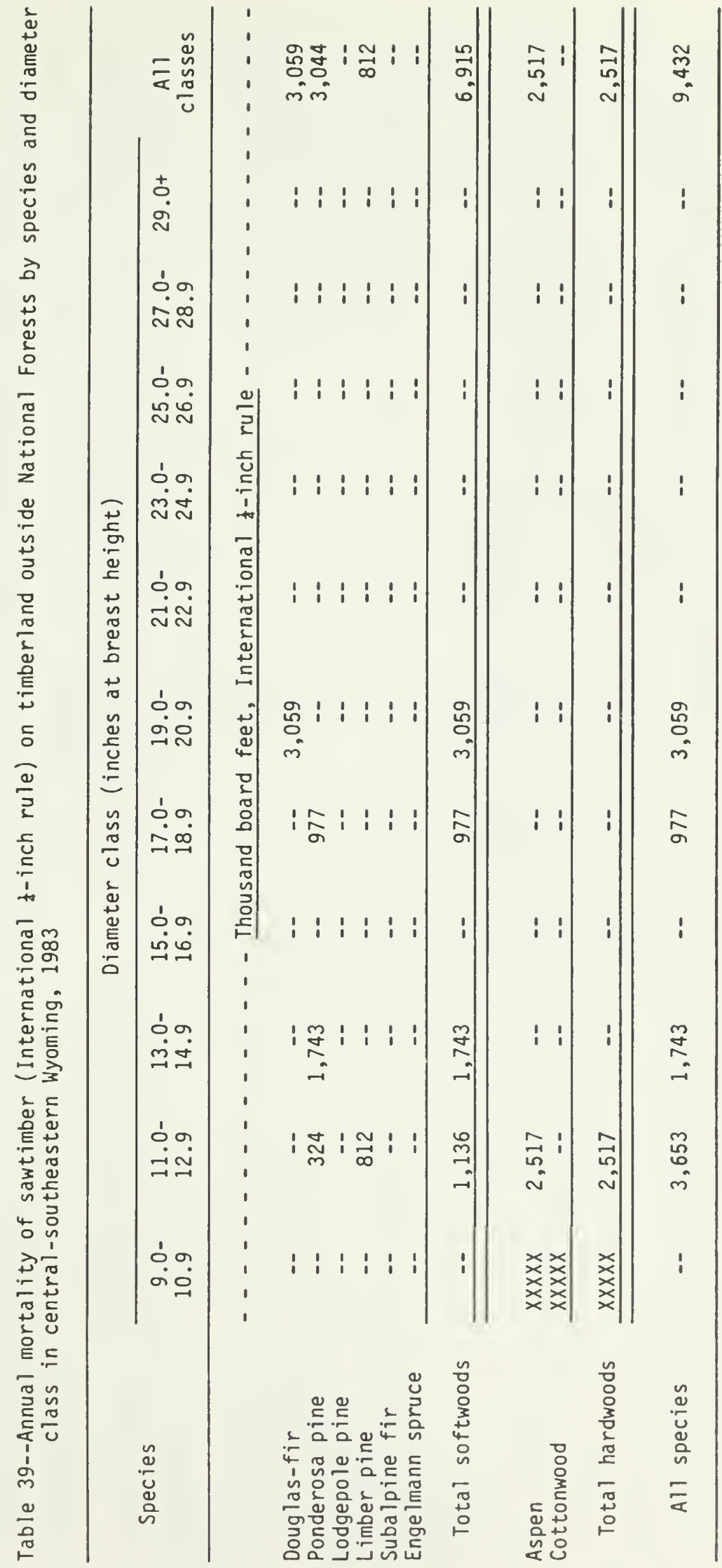




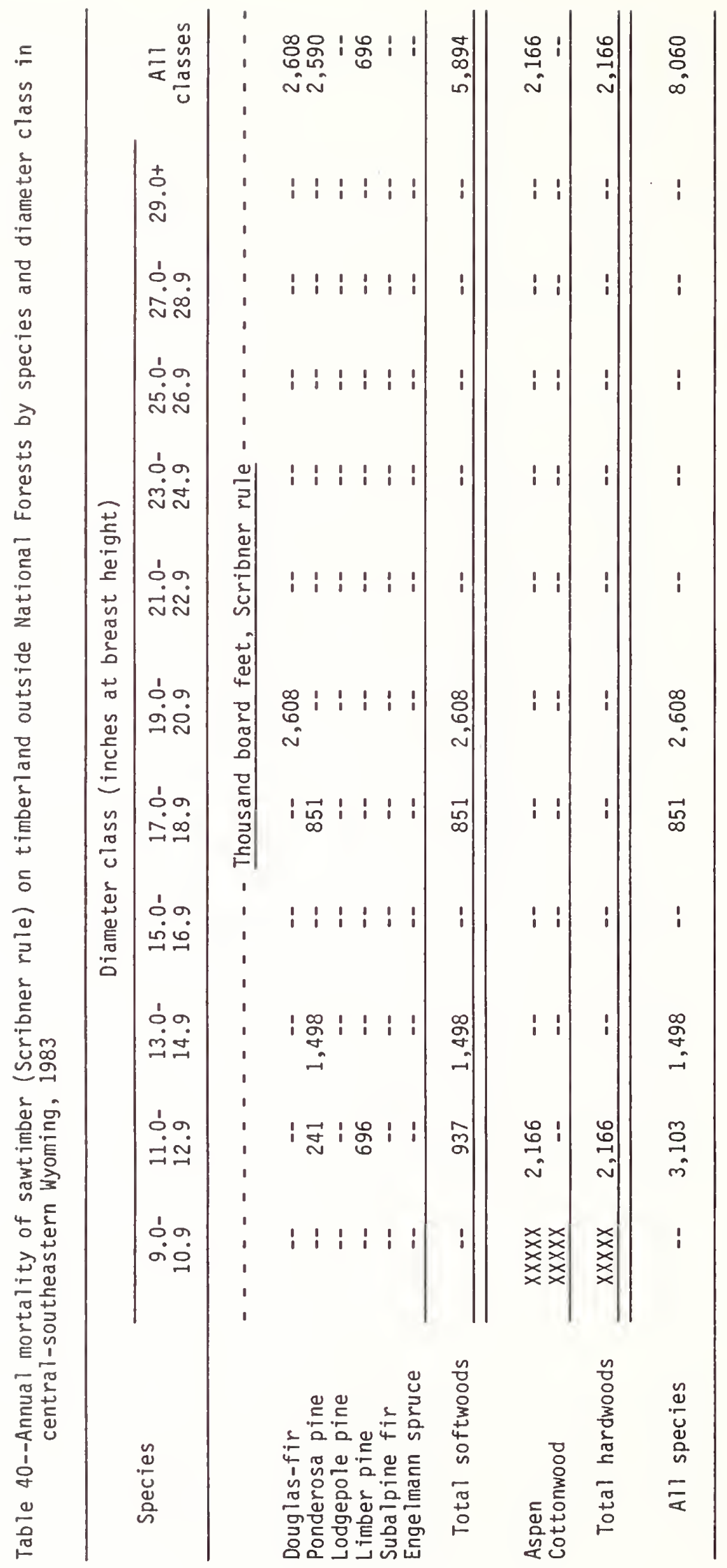




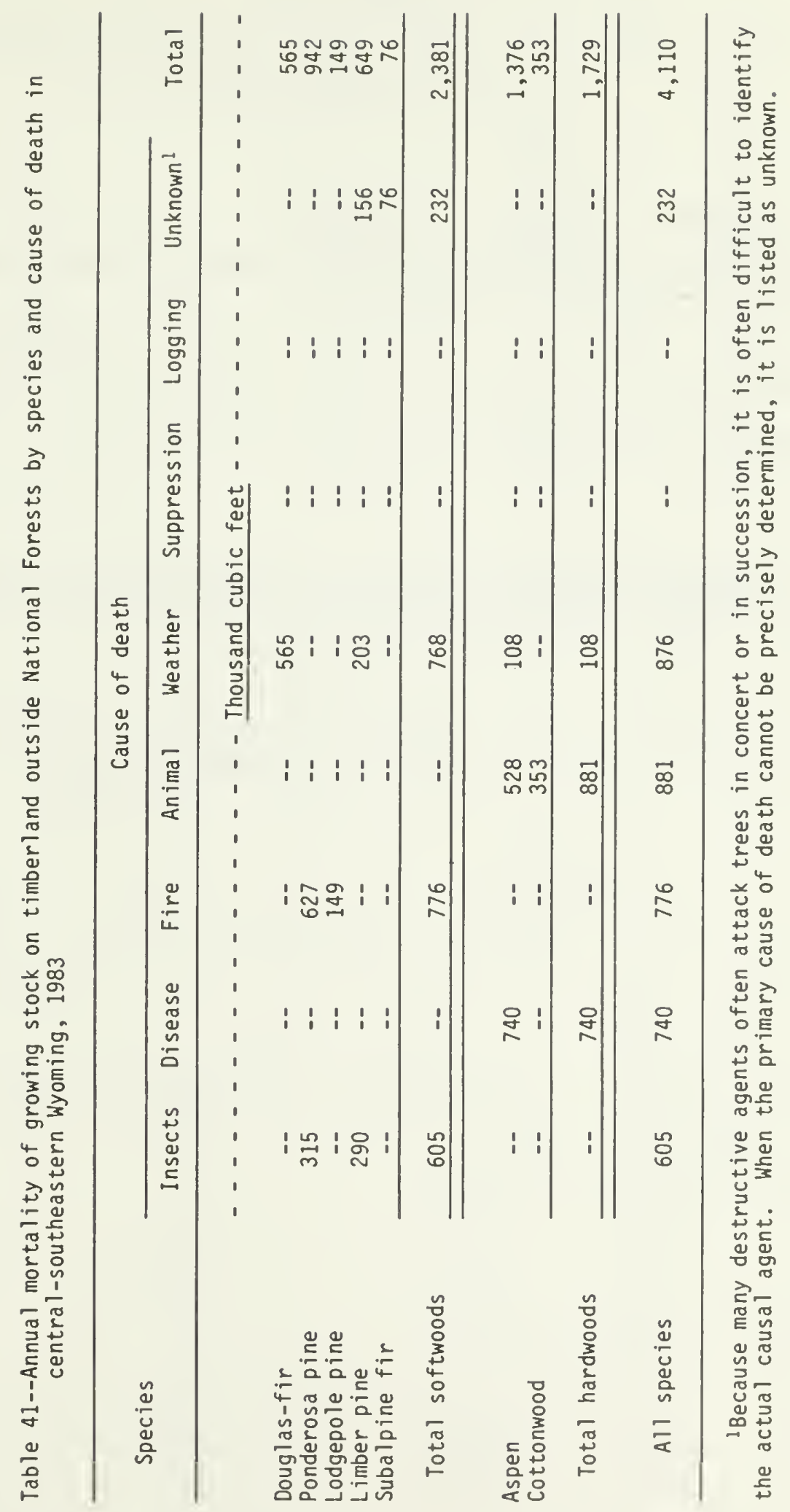


Table 42--Annual mortality of sawtimber (International s-inch rule) on timberland outside National Forests by species and cause of death in central-southeastern Wyoming, 1983

\begin{tabular}{|c|c|c|c|c|c|c|c|c|c|}
\hline \multirow{2}{*}{ Species } & \multicolumn{8}{|c|}{ Cause of death } & \multirow[b]{2}{*}{ Total } \\
\hline & Insects & Disease & Fire & Animal & Weather & Suppression & Logging & Unknown & \\
\hline & --- & --- & - Thou & $d$ board & et, Inter & ional $\$$-inch & rule - - & $-\cdot-$ & $\cdots-$ \\
\hline Douglas-fir & 560 & & 2483 & -- & 3,059 & -- & -- & -- & 3,059 \\
\hline Ponderosa pine & 560 & -- & 2,483 & -- & -- & - & -- & & 3,043 \\
\hline Lodgepole pine & -- & -- & -- & -- & 812 & -- & -- & -- & -- \\
\hline Limber pine & -- & -- & -- & -- & 812 & -- & -- & -- & 812 \\
\hline Subalpine fir & -- & -- & -- & -- & -- & -- & -- & -- & -- \\
\hline Total softwoods & 560 & -- & 2,483 & -- & 3,871 & -- & -- & -- & 6,914 \\
\hline Aspen & -- & 1,592 & -- & 926 & -- & -- & -- & -- & 2,518 \\
\hline Cottonwood & -- & -- & -- & -- & -- & -- & -- & -- & -- \\
\hline Total hardwoods & $=$ & 1,592 & -- & 926 & -- & -- & -- & -- & 2,518 \\
\hline All species & 560 & 1,592 & 2,483 & 926 & 3,871 & -- & -- & -- & 9,432 \\
\hline
\end{tabular}

Table 43--Annual mortality of sawtimber (Scribner rule) on timberland outside National Forests by species and cause of death in central-southeastern Wyoming, 1983

\begin{tabular}{|c|c|c|c|c|c|c|c|c|c|}
\hline \multirow{2}{*}{ Species } & \multicolumn{8}{|c|}{ Cause of death } & \multirow[b]{2}{*}{ Total } \\
\hline & Insects & Disease & Fire & Animal & Weather & Suppression & Logging & Unknown & \\
\hline & --- & $-\cdots$ & --- & Thousan & board fee & Scribner rul & --- & ---- & $\cdots$ \\
\hline Douglas-fir & -- & -- & -- & -- & 2,608 & -- & -- & -- & 2,608 \\
\hline Ponderosa pine & 484 & -- & 2,106 & -- & -- & -- & -- & -- & 2,590 \\
\hline Lodgepole pine & -- & -- & -- & -- & -- & -- & -- & $\cdots$ & -- \\
\hline Limber pine & -- & -- & -- & -- & 696 & -- & -- & -- & 696 \\
\hline Subalpine fir & -- & -- & -- & -- & -- & - & -- & -- & -- \\
\hline Total softwoods & 484 & -- & 2,106 & -- & 3,304 & -- & -- & -- & 5,894 \\
\hline Aspen & -- & 1,371 & -- & 795 & -- & -- & -- & -- & 2,166 \\
\hline Cottonwood & -- & -- & -- & -- & -- & -- & -- & -- & -- \\
\hline Total hardwoods & -- & 1,371 & -- & 795 & $\ldots$ & -- & -- & - & 2,166 \\
\hline All species & 484 & 1,371 & 2,106 & 795 & 3,304 & -- & -- & -- & 8,060 \\
\hline
\end{tabular}


Table 44--Area of woodland outside National Forests by forest type and ownership class in central-southeastern Wyoming, 1984

\begin{tabular}{|c|c|c|c|}
\hline \multirow{2}{*}{ Forest type } & \multicolumn{2}{|c|}{ Ownership class } & \multirow[b]{2}{*}{ Total } \\
\hline & $\begin{array}{l}\text { Other } \\
\text { public }\end{array}$ & Private & \\
\hline Juniper & $\begin{array}{r}\ldots \ldots \\
183,175 \\
\end{array}$ & $\begin{array}{r}- \text { Acres } \\
70,200 \\
\end{array}$ & $\begin{array}{l}--\ldots \\
253,375\end{array}$ \\
\hline Total woodland sof twoods & 183,175 & 70,200 & 253,375 \\
\hline $\begin{array}{l}\text { Mountain brushl } \\
\text { Riparian }\end{array}$ & $\begin{array}{r}7,632 \\
-- \\
\end{array}$ & 20,057 & $\begin{array}{r}7,632 \\
20,057 \\
\end{array}$ \\
\hline Total woodland hardwoods & 7,632 & 20,057 & 27,689 \\
\hline All types & 190,807 & 90,257 & 281,064 \\
\hline
\end{tabular}

IMountain brush and riparian hardwood forest types are shown separately on this table only. These types are included in the "other" forest type category on the remaining woodland tables.

Table 45--Area of woodland outside National Forests by ownership class, forest type, and productivity class in central-southeastern Wyoming, 1984

\begin{tabular}{|c|c|c|c|c|}
\hline \multirow{2}{*}{$\begin{array}{l}\text { Ownership } \\
\text { class }\end{array}$} & \multirow{2}{*}{ Forest type } & \multicolumn{2}{|c|}{ Productivity class } & \multirow[b]{2}{*}{$\begin{array}{c}\text { All } \\
\text { classes }\end{array}$} \\
\hline & & $\mathrm{High}$ & Low & \\
\hline & & $\ldots$ & - Acres - & $\ldots$ \\
\hline \multirow[t]{2}{*}{ Other public: } & $\begin{array}{l}\text { Juniper } \\
\text { Other }\end{array}$ & $\begin{array}{r}106,852 \\
- \\
\end{array}$ & $\begin{array}{r}76,323 \\
7,632 \\
\end{array}$ & $\begin{array}{r}183,175 \\
7,632 \\
\end{array}$ \\
\hline & Total & 106,852 & 83,955 & 190,807 \\
\hline \multirow[t]{2}{*}{ Private: } & $\begin{array}{l}\text { Juniper } \\
\text { Other }\end{array}$ & $\begin{array}{l}30,086 \\
20,057 \\
\end{array}$ & $\begin{array}{r}40,114 \\
- \\
\end{array}$ & $\begin{array}{l}70,200 \\
20,057 \\
\end{array}$ \\
\hline & Total & 50,143 & 40,114 & 90,257 \\
\hline \multirow[t]{2}{*}{ Total: } & $\begin{array}{l}\text { Juniper } \\
\text { Other }\end{array}$ & $\begin{array}{r}136,938 \\
20,057 \\
\end{array}$ & $\begin{array}{r}116,437 \\
7,632 \\
\end{array}$ & $\begin{array}{r}253,375 \\
27,689 \\
\end{array}$ \\
\hline & Total & 156,995 & 124,069 & 281,064 \\
\hline
\end{tabular}




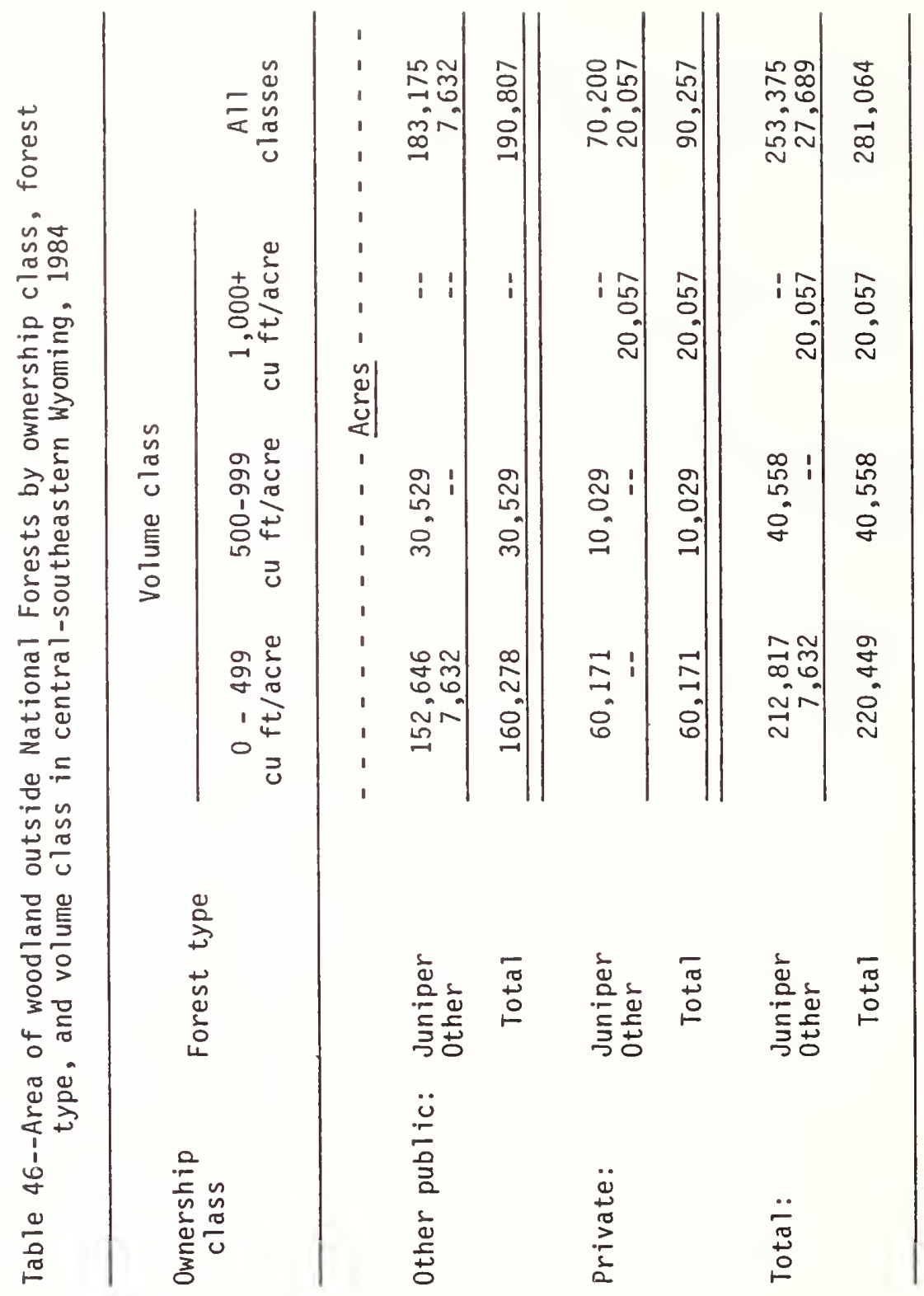




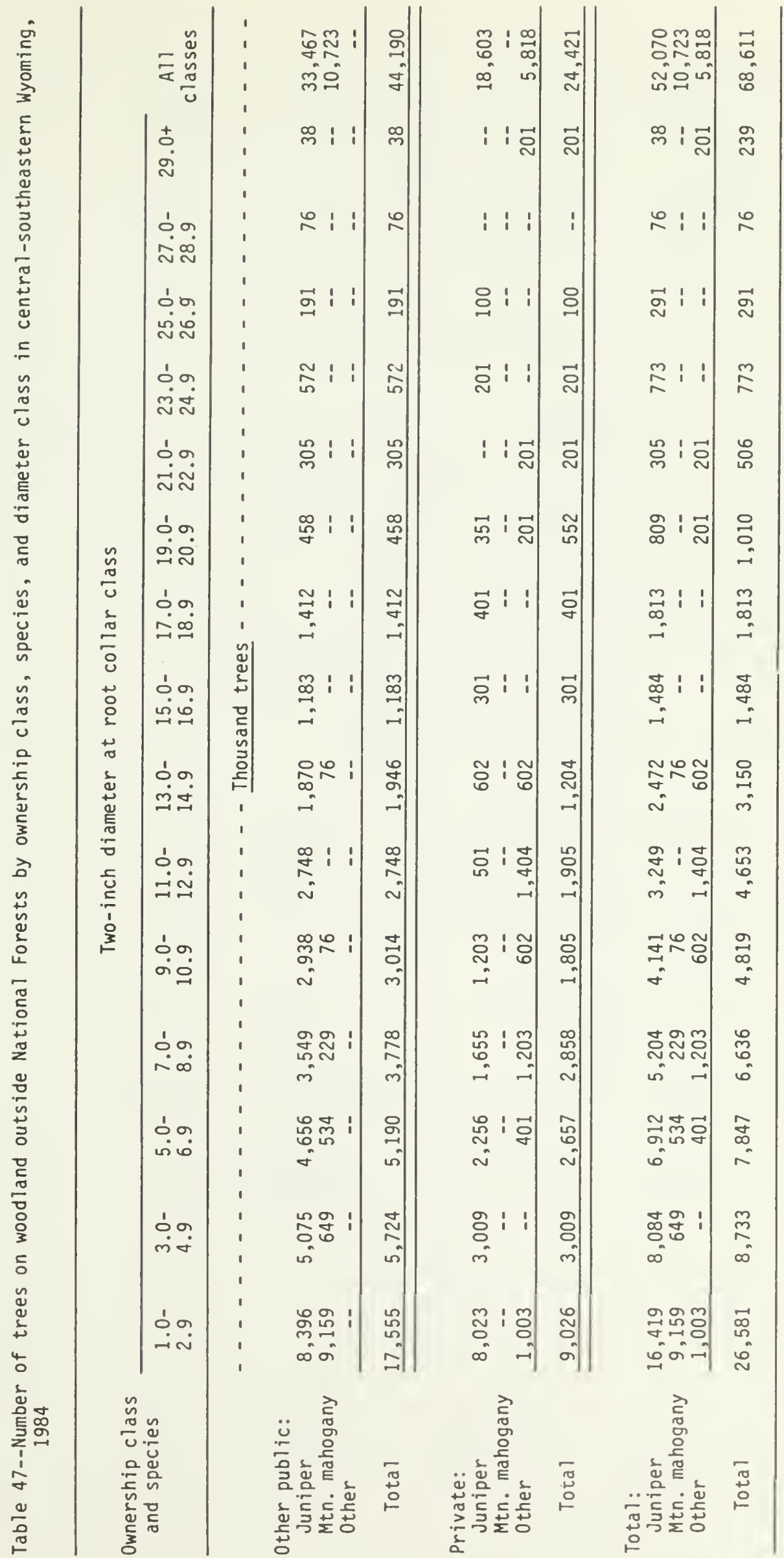




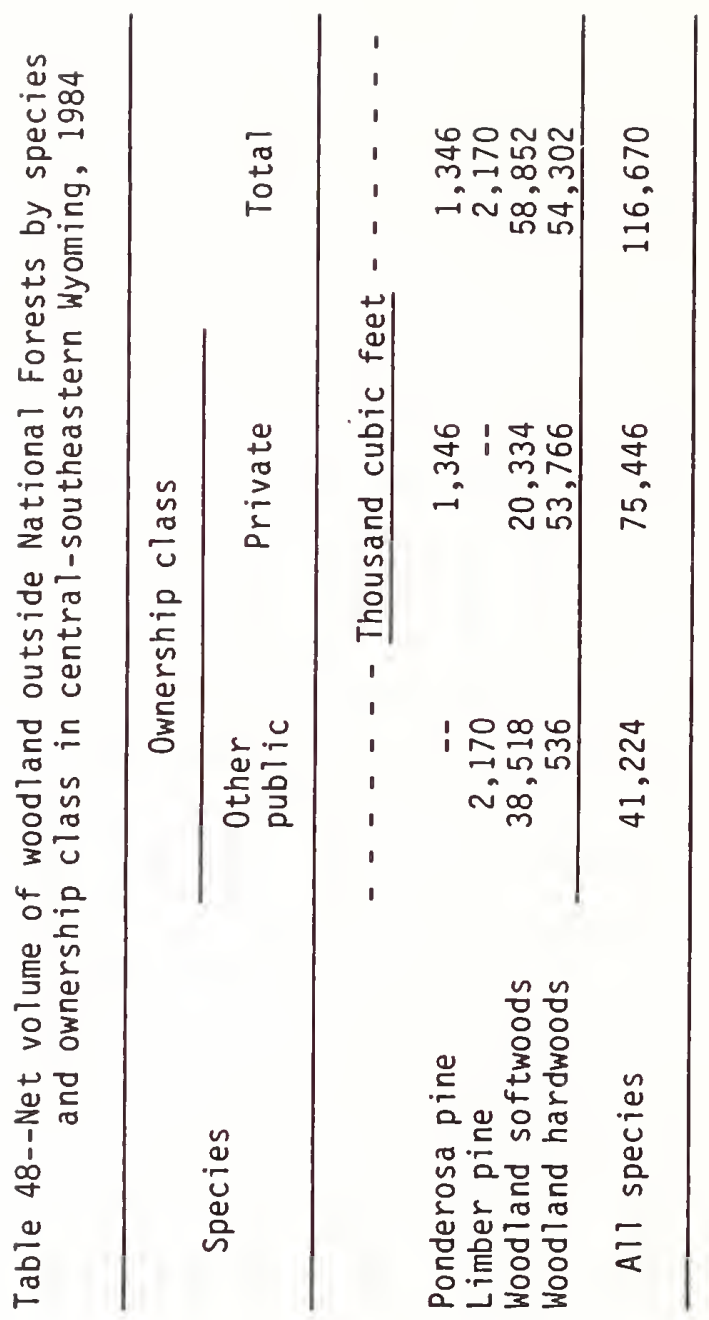




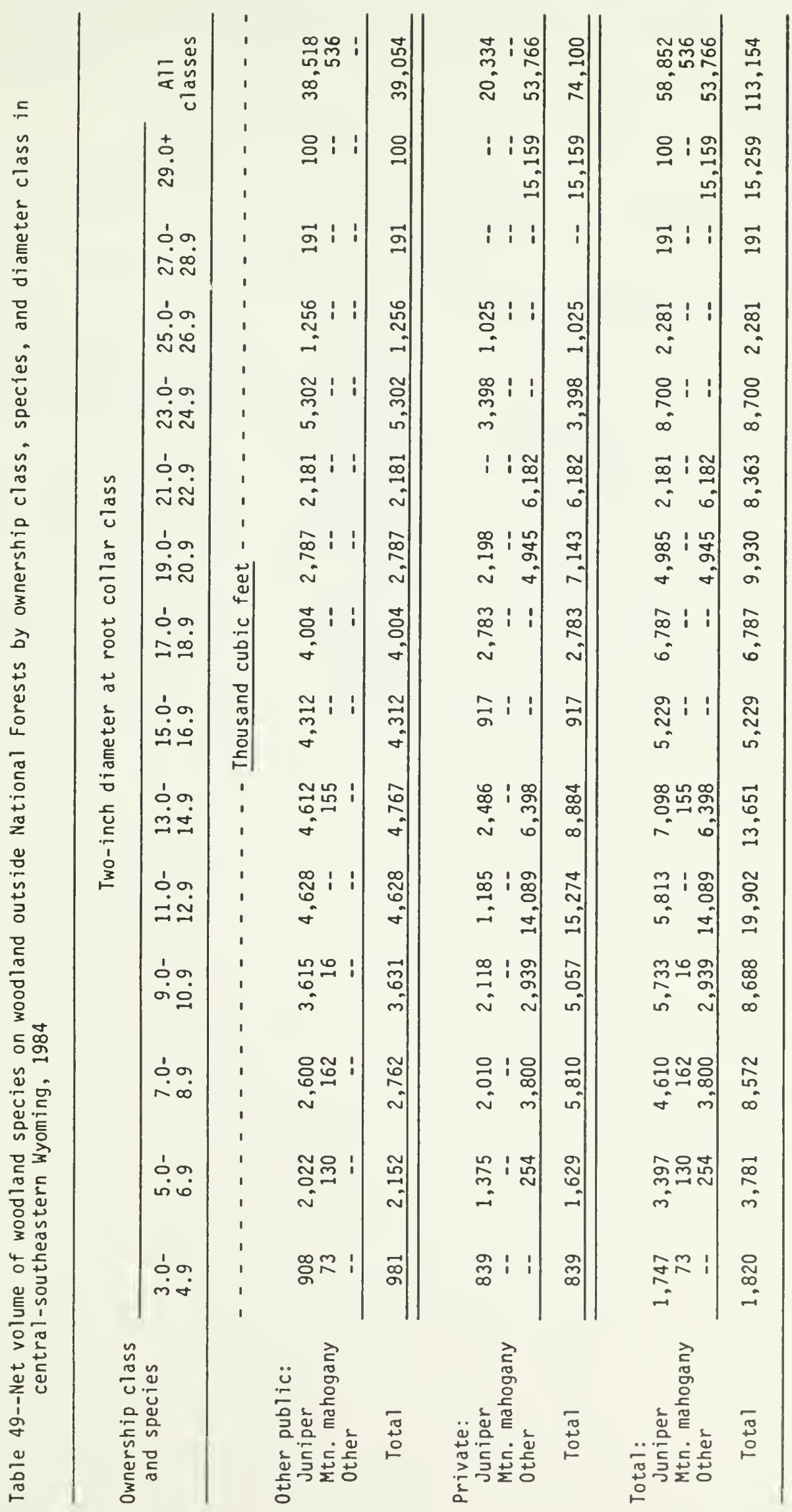


Table 50--Net volume of woodland species on woodland outside National Forests by ownership class, forest type, and productivity class in central-southeastern Wyoming, 1984

\begin{tabular}{|c|c|c|c|c|}
\hline \multirow{2}{*}{$\begin{array}{l}\text { Ownership } \\
\text { class }\end{array}$} & \multirow{2}{*}{ Forest type } & \multicolumn{2}{|c|}{ Productivity class } & \multirow[b]{2}{*}{$\begin{array}{c}\text { All } \\
\text { classes }\end{array}$} \\
\hline & & $\mathrm{High}$ & Low & \\
\hline & & $-\cdots-I$ & nd cubic & --- \\
\hline \multirow[t]{2}{*}{ Other public: } & $\begin{array}{l}\text { Juniper } \\
\text { Other }\end{array}$ & $\begin{array}{r}28,976 \\
-- \\
\end{array}$ & $\begin{array}{r}9,523 \\
555 \\
\end{array}$ & $\begin{array}{r}38,499 \\
555 \\
\end{array}$ \\
\hline & Total & 28,976 & 10,078 & 39,054 \\
\hline \multirow[t]{2}{*}{ Private: } & $\begin{array}{l}\text { Juniper } \\
\text { Other }\end{array}$ & $\begin{array}{l}11,217 \\
53,766 \\
\end{array}$ & $\begin{array}{r}9,117 \\
-- \\
\end{array}$ & $\begin{array}{r}20,334 \\
53,766 \\
\end{array}$ \\
\hline & Total & 64,983 & 9,117 & 74,100 \\
\hline \multirow[t]{2}{*}{ Total: } & $\begin{array}{l}\text { Juniper } \\
\text { Other }\end{array}$ & $\begin{array}{l}40,193 \\
53,766 \\
\end{array}$ & $\begin{array}{r}18,640 \\
555 \\
\end{array}$ & $\begin{array}{r}58,833 \\
54,321 \\
\end{array}$ \\
\hline & Total & 93,959 & 19,195 & 113,154 \\
\hline
\end{tabular}


Table 51--Net volume of woodland species on woodland outside National Forests by ownership class, forest type, and volume class in central-southeastern Wyoming, 1984

\begin{tabular}{|c|c|c|c|c|c|}
\hline \multirow{2}{*}{$\begin{array}{c}\text { Ownership } \\
\text { class }\end{array}$} & \multirow{2}{*}{ Forest type } & \multicolumn{3}{|c|}{ Volume class } & \multirow[b]{2}{*}{$\begin{array}{c}\text { All } \\
\text { classes }\end{array}$} \\
\hline & & $\begin{array}{c}0-499 \\
c u f t / a c r e\end{array}$ & $\begin{array}{c}500-999 \\
\mathrm{cu} \mathrm{ft/acre}\end{array}$ & $\begin{array}{c}1,000+ \\
\mathrm{cu} \text { ft/acre }\end{array}$ & \\
\hline \multirow[t]{2}{*}{ Other public: } & $\begin{array}{l}\text { Juniper } \\
\text { Other }\end{array}$ & $\begin{array}{r}\ldots \ldots \\
23,025 \\
555 \\
\end{array}$ & $\begin{array}{r}- \text { Thousand } \\
15,474 \\
--\end{array}$ & $\begin{array}{r}\text { Abic feet - } \\
-- \\
--\end{array}$ & $\begin{array}{r}-\ldots- \\
38,499 \\
555 \\
\end{array}$ \\
\hline & Total & 23,580 & 15,474 & -- & 39,054 \\
\hline \multirow[t]{2}{*}{ Private: } & $\begin{array}{l}\text { Juniper } \\
\text { Other }\end{array}$ & $\begin{array}{r}12,955 \\
-- \\
\end{array}$ & $\begin{array}{r}7,379 \\
-- \\
\end{array}$ & 53,766 & $\begin{array}{l}20,334 \\
53,766 \\
\end{array}$ \\
\hline & Total & 12,955 & 7,379 & 53,766 & 74,100 \\
\hline \multirow[t]{2}{*}{ Tota 1: } & $\begin{array}{l}\text { Juniper } \\
\text { Other }\end{array}$ & $\begin{array}{r}35,980 \\
555 \\
\end{array}$ & $\begin{array}{r}22,853 \\
-- \\
\end{array}$ & 53,766 & $\begin{array}{l}58,833 \\
54,321 \\
\end{array}$ \\
\hline & Total & 36,535 & 22,853 & 53,766 & 113,154 \\
\hline
\end{tabular}




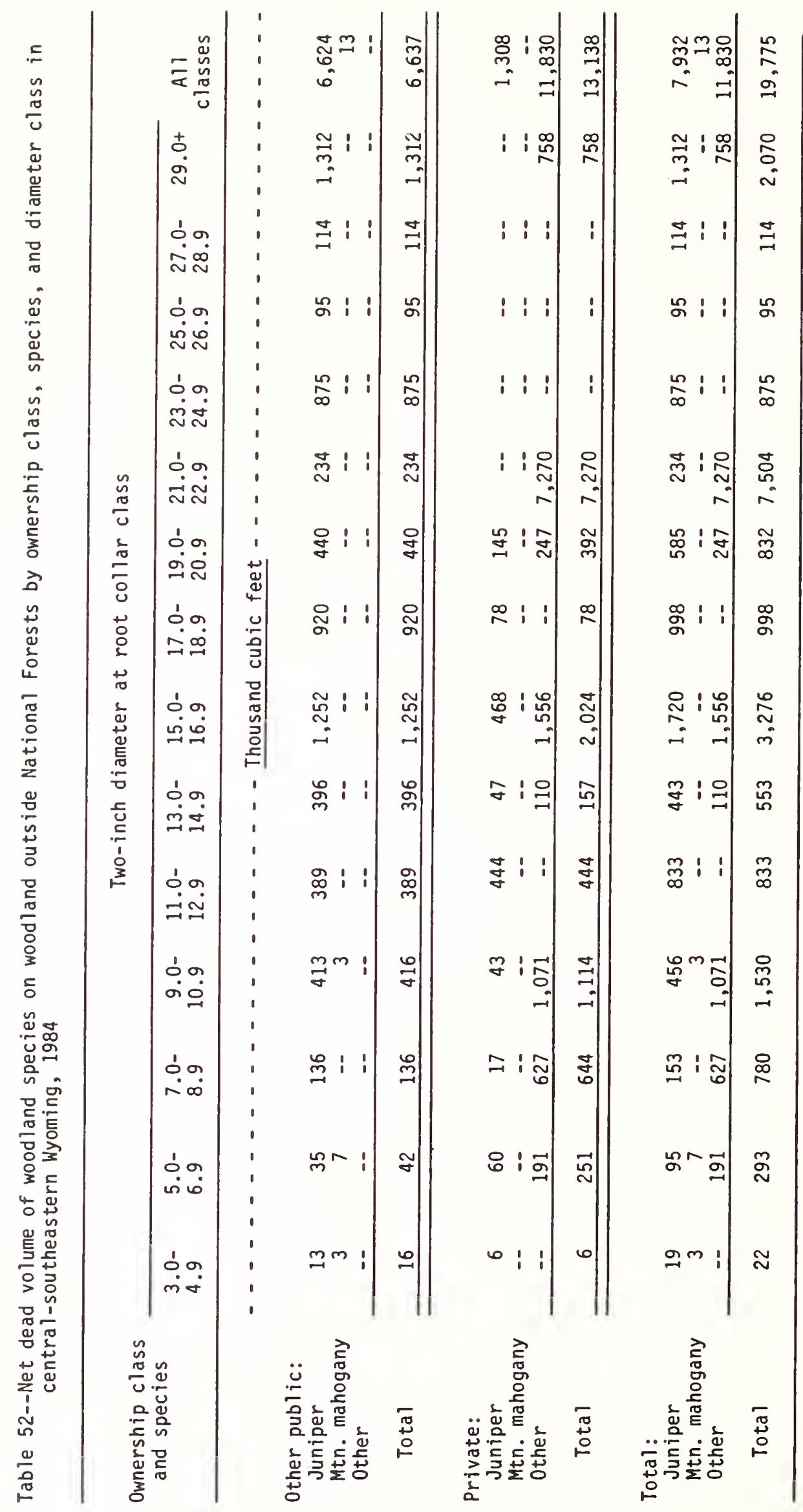




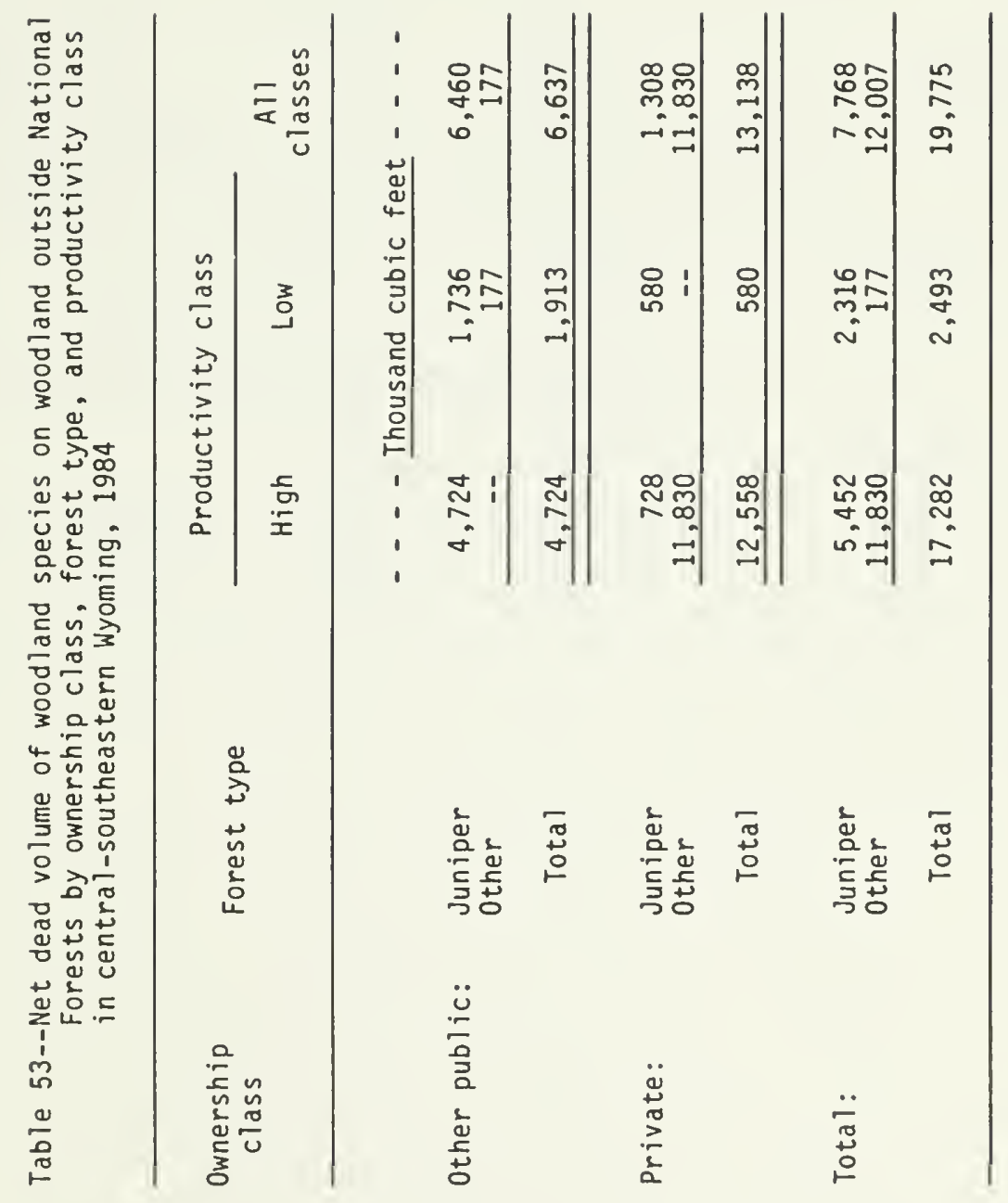


Table 54--Net dead volume of woodland species on woodland outside National Forests by ownership class, forest type, and volume class in central-southeastern Wyoming, 1984

\begin{tabular}{|c|c|c|c|c|c|}
\hline \multirow{2}{*}{$\begin{array}{l}\text { Ownership } \\
\text { class }\end{array}$} & \multirow{2}{*}{ Forest type } & \multicolumn{3}{|c|}{ Volume class } & \multirow[b]{2}{*}{$\begin{array}{c}\text { All } \\
\text { classes }\end{array}$} \\
\hline & & $\begin{array}{c}0-49.9 \\
\text { cu ft/acre }\end{array}$ & $\begin{array}{c}500-999 \\
\text { cu ft/acre }\end{array}$ & $\begin{array}{c}1,000+ \\
\mathrm{cu} f \mathrm{ft} / \mathrm{acre}\end{array}$ & \\
\hline \multirow{3}{*}{ Other public: } & & $-\cdot-\cdot-$ & - Thousand & ubic feet - & $-\cdots$ \\
\hline & $\begin{array}{l}\text { Juniper } \\
\text { Other }\end{array}$ & $\begin{array}{r}4,334 \\
177 \\
\end{array}$ & $\begin{array}{r}2,126 \\
-- \\
\end{array}$ & $\begin{array}{l}-- \\
-- \\
\end{array}$ & $\begin{array}{r}6,460 \\
177 \\
\end{array}$ \\
\hline & Total & 4,511 & 2,126 & - & 6,637 \\
\hline \multirow[t]{2}{*}{ Private: } & $\begin{array}{l}\text { Juniper } \\
\text { Other }\end{array}$ & $\begin{array}{r}1,218 \\
- \\
\end{array}$ & $\begin{array}{l}90 \\
-- \\
\end{array}$ & $11,830^{--}$ & $\begin{array}{r}1,308 \\
11,830 \\
\end{array}$ \\
\hline & Total & 1,218 & 90 & 11,830 & 13,138 \\
\hline \multirow[t]{2}{*}{ Tota 1: } & $\begin{array}{l}\text { Juniper } \\
\text { Other }\end{array}$ & $\begin{array}{r}5,552 \\
177 \\
\end{array}$ & $\begin{array}{r}2,216 \\
\ldots \\
\end{array}$ & 11,830 & $\begin{array}{r}7,768 \\
12,007 \\
\end{array}$ \\
\hline & Total & 5,729 & 2,216 & 11,830 & 19,775 \\
\hline
\end{tabular}


Table 55--Net annual growth on woodland outside National Forests by species and ownership class in central-southeastern Wyoming, 1983

\begin{tabular}{|c|c|c|c|}
\hline \multirow{2}{*}{ Species } & \multicolumn{2}{|c|}{ Ownership class } & \multirow[b]{2}{*}{ Total } \\
\hline & $\begin{array}{l}\text { Other } \\
\text { public }\end{array}$ & Private & \\
\hline & $-\cdots$ & and cubic & --- \\
\hline $\begin{array}{l}\text { Ponderosa pine } \\
\text { Limber pine } \\
\text { Woodland softwoods } \\
\text { Woodland hardwoods }\end{array}$ & $\begin{array}{r}-- \\
19 \\
445 \\
6 \\
\end{array}$ & $\begin{array}{r}13 \\
-- \\
178 \\
1,008 \\
\end{array}$ & $\begin{array}{r}13 \\
19 \\
623 \\
1,014 \\
\end{array}$ \\
\hline All species & 470 & 1,199 & 1,669 \\
\hline
\end{tabular}




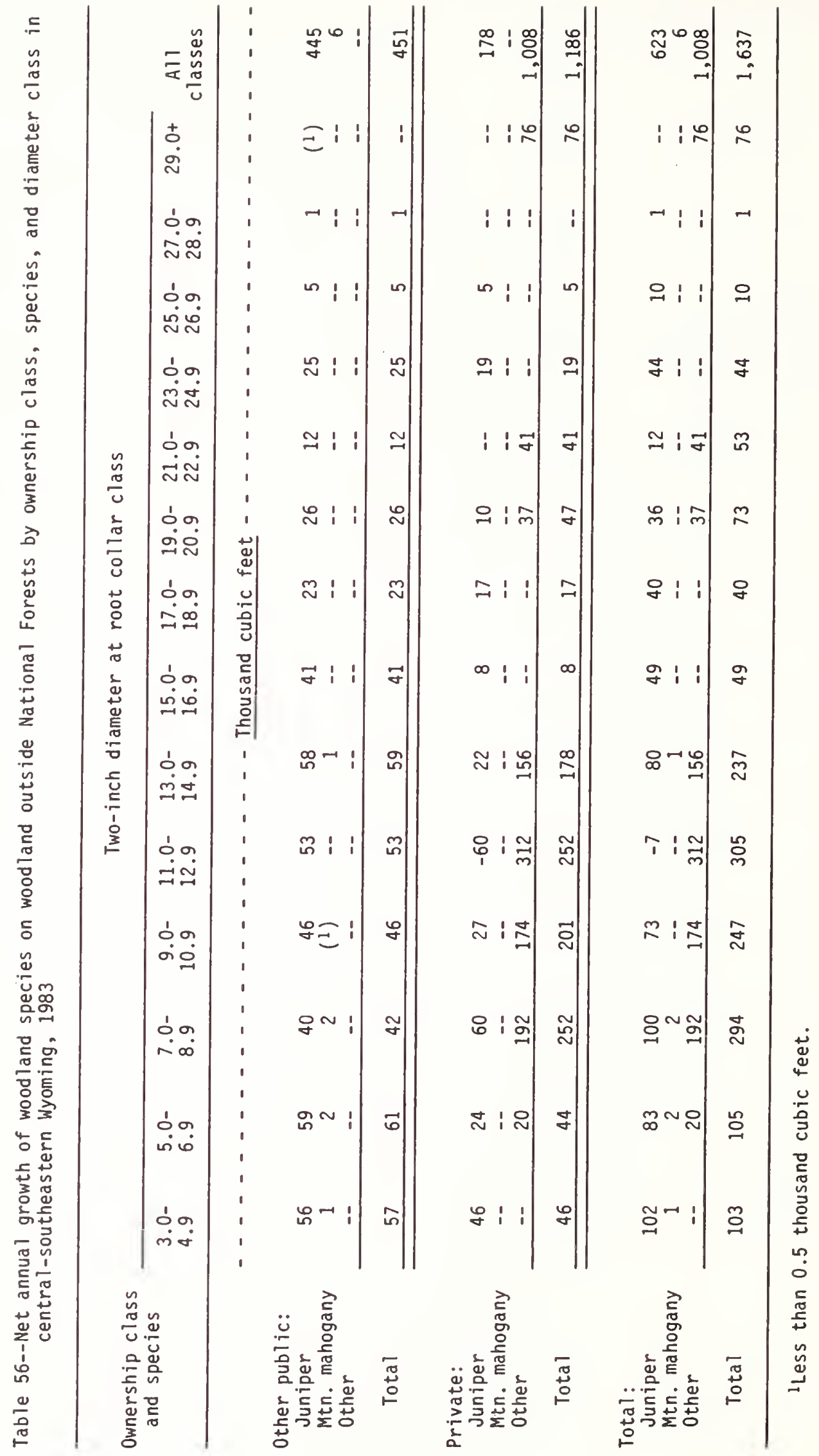


Table 57--Net annual growth of woodland species on woodland outside National Forests by ownership class, forest type, and productivity class in central-southeastern Wyoming, 1983

\begin{tabular}{|c|c|c|c|c|}
\hline \multirow{2}{*}{$\begin{array}{c}\text { Ownership } \\
\text { class }\end{array}$} & \multirow{2}{*}{ Forest type } & \multicolumn{2}{|c|}{ Productivity class } & \multirow[b]{2}{*}{$\begin{array}{c}\text { All } \\
\text { classes }\end{array}$} \\
\hline & & High & Low & \\
\hline & & $-\cdots-I$ & cubic & $\cdots$ \\
\hline \multirow[t]{2}{*}{ Other public: } & $\begin{array}{l}\text { Juniper } \\
\text { Other }\end{array}$ & $\begin{array}{r}338 \\
-- \\
\end{array}$ & $\begin{array}{r}109 \\
4 \\
\end{array}$ & $\begin{array}{r}447 \\
4 \\
\end{array}$ \\
\hline & Total & 338 & 113 & 451 \\
\hline \multirow[t]{2}{*}{ Private: } & $\begin{array}{l}\text { Juniper } \\
\text { Other }\end{array}$ & $\begin{array}{r}17 \\
1,008 \\
\end{array}$ & $\begin{array}{r}161 \\
-- \\
\end{array}$ & $\begin{array}{r}178 \\
1,008 \\
\end{array}$ \\
\hline & Total & 1,025 & 161 & 1,186 \\
\hline \multirow[t]{2}{*}{ Total: } & $\begin{array}{l}\text { Juniper } \\
\text { Other }\end{array}$ & $\begin{array}{r}355 \\
1,008 \\
\end{array}$ & $\begin{array}{r}270 \\
4 \\
\end{array}$ & $\begin{array}{r}625 \\
1,012 \\
\end{array}$ \\
\hline & Total & 1,363 & 274 & 1,637 \\
\hline
\end{tabular}


Table 58--Net annual growth of woodland species on woodland outside National Forests by ownership class, forest type, and volume class in central-southeastern Wyoming, 1983

Ownership
class

Volume class

$\begin{array}{cccc}0-499 & 500-999 & 1,000+ & \text { All } \\ \text { cu ft/acre } & \text { cu ft/acre } & \text { cu ft/acre } & \text { classes }\end{array}$

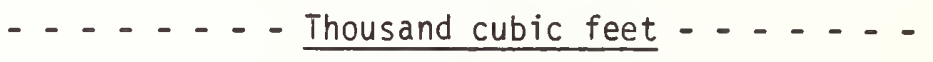

\begin{tabular}{|c|c|c|c|c|c|}
\hline \multirow[t]{2}{*}{ Other public: } & $\begin{array}{l}\text { Juniper } \\
\text { Other }\end{array}$ & $\begin{array}{r}295 \\
4 \\
\end{array}$ & $\begin{array}{r}152 \\
-- \\
\end{array}$ & $\begin{array}{l}-- \\
-- \\
\end{array}$ & $\begin{array}{r}447 \\
4 \\
\end{array}$ \\
\hline & Total & 299 & 152 & -- & 451 \\
\hline \multirow[t]{2}{*}{ Private: } & $\begin{array}{l}\text { Juniper } \\
\text { Other }\end{array}$ & $\begin{array}{r}127 \\
-- \\
\end{array}$ & $\begin{array}{l}51 \\
-- \\
\end{array}$ & 1,008 & $\begin{array}{r}178 \\
1,008 \\
\end{array}$ \\
\hline & Total & 127 & 51 & 1,008 & 1,186 \\
\hline \multirow[t]{2}{*}{ Total: } & $\begin{array}{l}\text { Juniper } \\
\text { Other }\end{array}$ & $\begin{array}{r}422 \\
4 \\
\end{array}$ & $\begin{array}{r}203 \\
-- \\
\end{array}$ & 1,008 & $\begin{array}{r}625 \\
1,012 \\
\end{array}$ \\
\hline & Total & 426 & 203 & 1,008 & 1,637 \\
\hline
\end{tabular}

Table 59--Number of fenceposts on woodland outside National Forests by ownership class, species, and type of post in central-southeastern Wyoming, 1984

\begin{tabular}{|c|c|c|c|c|}
\hline \multirow{2}{*}{$\begin{array}{l}\text { Ownership } \\
\text { class }\end{array}$} & \multirow{2}{*}{ Species } & \multicolumn{2}{|c|}{ Type of post } & \multirow[b]{2}{*}{ Total } \\
\hline & & Line & Corner & \\
\hline & & $-\cdots I$ & nd fence & $-\cdots$ \\
\hline Other public: & Juniper & 6,405 & 3,056 & 9,461 \\
\hline Private: & Juniper & 6,668 & 2,781 & 9,449 \\
\hline Total & Juniper & 13,073 & 5,837 & 18,910 \\
\hline
\end{tabular}






Green, Alan W.; Conner, Roger C. 1988. Timberland and woodland resources outside National Forests in central and southeastern Wyoming, 1984. Resour. Bull. INT-53. Ogden, UT: U.S. Department of Agriculture, Forest Service, Intermountain

Research Station. $58 \mathrm{p}$.

Highlights the results of forest inventory of the 12 counties in central and southeastern Wyoming. Presents area, volume, growth, and mortality statistics for both timberland and woodlands outside the National Forests as of 1984.

KEYWORDS: softwoods, hardwoods, growing-stock and sawtimber volumes, net annual growth, harvest 


\section{INTERMOUNTAIN RESEARCH STATION}

The Intermountain Research Station provides scientific knowledge and technology to improve management, protection, and use of the forests and rangelands of the Intermountain West. Research is designed to meet the needs of National Forest managers, Federal and State agencies, industry, academic institutions, public and private organizations, and individuals. Results of research are made available through publications, symposia, workshops, training sessions, and personal contacts.

The Intermountain Research Station territory includes Montana, Idaho, Utah, Nevada, and westem Wyoming. Eighty-five percent of the lands in the Station area, about 231 million acres, are classified as forest or rangeland. They include grasslands, deserts, shrublands, alpine areas, and forests. They provide fiber for forest industries, minerals and fossil fuels for energy and industrial development, water for domestic and industrial consumption, forage for livestock and wildlife, and recreation opportunities for millions of visitors.

Several Station units conduct research in additional western States, or have missions that are national or international in scope.

Station laboratories are located in:

Boise, Idaho

Bozeman, Montana (in cooperation with Montana State University)

Logan, Utah (in cooperation with Utah State University)

Missoula, Montana (in cooperation with the University of Montana)

Moscow, Idaho (in cooperation with the University of Idaho)

Ogden, Utah

Provo, Utah (in cooperation with Brigham Young University)

Reno, Nevada (in cooperation with the University of Nevada)

USDA policy prohibits discrimination because of race, color, national origin, sex, age, religion, or handicapping condition. Any person who believes he or she has been discriminated against in any USDA-related activity should immediately contact the Secretary of Agriculture, Washington, DC 20250. 